\title{
Evaluation of Liquid-Fed Ceramic Melter Off-Gas System Technologies for the Hanford Waste Vitrification Plant
}

R. W. Goles

A. J. Schmidt

June1992

Prepared for the U.S. Department of Energy under Contract DE-AC06-76RLO 1830

Pacific Northwest Laboratory Operated for the U.S. Department of Energy by Battelle Memorial Institute 


\title{
DISCLAIMER
}

This report was prepared as an account of work sponsored by an agency of the United States Government. Neither the United States Government nor any agency thereof, nor Battelle Memorial Institute, nor any of their employees, makes any warranty, expressed or implied, or assumes any legal liability or responsibility for the accuracy, completeness, or usefulnessofany information, apparatus, product, or processdisclosed, or represents that its use would not infringe privately owned rights. Reference herein to any specific commercial product, process, or serviceby trade name, trademark, manufacturer, or otherwise does not necessarily constitute or imply its endorsement, recommendation, or favoring by the United States Government or any agency thereof, or Battelle Memorial Institute. The views and opinions of authors expressed herein do not necessarily state or reflect those of the United States Government or any agency thereof.

\author{
PACIFIC NORTHWEST LABORATORY \\ operatedby \\ BATTELLE MEMORIAL INSTITUTE \\ for the \\ UNITED STATES DEPARTMENT OF ENERGY \\ under Contract DE-AC06-76RLO 1830
}

Printed in the United States of America

Available to DOE and DOE contractors from the

Office of Scientific and Technical Information, P.O. Box 62, Oak Ridge, TN 37831; prices available from (615) 576-8401. FTS 626-8401.

Available to the public from the National Technical Information Senvice, U.S. Department of Commerce, 5285 Port Royal Rd., Springfield, VA 22161 
PNL-8109 UC -721

EVALUATION OF LIQUID-FED CERAMIC MELTER OFF-GAS SYSTEM TECHNOLOGIES FOR THE HANFORD WASTE VITRIFICATION PLANT

R. W. Goles

6

A. J. Schmidt

June 1992

Prepared for

the U.S. Department of Energy

under Contract DE-AC06-76RLO 1830

Pacific Northwest Laboratory

Richland, Washington 99352 



\section{SUMMARY}

The off-gas performance characteristics of the DWPF, WWD, and HWP process off-gas (POG) systems have been evaluated under normal and off-normal HWP processing conditions. The effectiveness of both the melter off-gas (MOG) and the corresponding process vessel ventilation (PVV) systems were evaluated on the basis of their effluent emission abatement performance, from which a combined POG emission (stack) source term was established. Each offgas technology was then compared on the basis of these projected stack emissions. Conclusions drawn from these POG performance evaluations are as follows:

- Under normal processing conditions, all three systems will behave similarly and provide nominall y equivalent public exposure protection due to the dominating influence of gaseous radionuclide emissions.

- All systems are capable of meeting public exposure limits at the point of atmospheric injection (the stack) under normal reference processing rates.

- Melter off-gas surging was found to have the greatest effect on the HWP source term. However, this transient condition was found to affect all off-gas technologies equivalently, since they all possess similar gaseous effluent abatement capabilities.

The DWF off-gas technology is 20 times more efficient in reducing plant emissions during melter idling than are the HWVP and WWDP systems. However, HWP and WDP idling stack emissions are 'projected to be only $0.02 \%$ of the normal process release rate.

The effects of MOG system failure upon plant releases vary depending upon the off-gas technol ogy modeled.

- DWF MOG system failure will not influence the plant source term since its MOG back-up system is totally redundant.

HMP MOG system failure is projected to result in a 100 -fold decrease in POG aerosol emission abatement capabilities. However, transient plant emissions (dose basis) will increase by only $-2 \%$ during cold cap burnoff due to the dominating influence of gaseous radionuclides. Once processing has ceased, stack emissions will remain at $1 \%$ of the normal processing release rate. 
- WVDP MOG system failure is incompatible with unfiltered HMP process cell design, as this technology does not provide for an MOG back-up system.

The secondary waste generation characteristics for the alternative offgas system designs have been evaluated. The principal sources of secondary waste examined are solid waste (failed or decommissioned equipment) and liquid waste (process effluent and decontamination solution). The results of the secondary waste evaluation are summarized below.

- The liquid and solid secondary waste generation rates of the HMP and the WWP off-gas systems are essentially equivalent.

- The DWPF off-gas system appears to have the potential to generate approximately twice the weight of solid waste and roughly five times the liquid waste of the HMP off-gas system.

The energy required to operate the melter and vessel ventilation off-gas systems for HWP, DWPF, and WMP have been estimated. To provide for a normalized comparison, HMP melter and vessel vent off-gas source terms were used for a.11 three technologies. The energy analysis is therefore based upon the energy required to process a set quantity and composition of off-gas. The primary conclusions from the energy analysis are as follows:

- The differences in energy consumption and energy costs between the HWVP and the WDP off-gas systems are insignificant.

- The DWF off-gas technology is the most energy-consuming. The energy costs associated with the operation of the DWPF off-gas technology will be four times greater than the other two systems.

- The primary difference in energy requirements between the HWP and the DWF systems is the steam required by the DWPF's steam-atomized scrubbers.

- For each off-gas system, the majority of energy costs will be incurred in the treatment of the accumulated liquid effluent (condensed steam). 


\section{ACRONYMS AND ABBREVIATIONS}

$\begin{array}{ll}\text { AC } & \text { alternating current } \\ \text { ACFM } & \text { actual cubic feet per minute } \\ \text { ANSI } & \text { American National Standards Institute } \\ \text { CFR } & \text { Code of Federal Regulations } \\ \text { DCG } & \text { derived concentration guide } \\ \text { DF } & \text { decontamination factor } \\ \text { DOE } & \text { Department of Energy } \\ \text { DWPF } & \text { Defense Waste Processing Facility } \\ \text { DWIT } & \text { decontamination waste treatment tank } \\ \text { ESOM } & \text { engineering-scale ceramic melter } \\ \text { EVS } & \text { ejector-venturi scrubber } \\ \text { FAVC } & \text { formic acid vent condenser } \\ \text { FC } & \text { film cooler } \\ \text { HEVE } & \text { high-efficiency mist eliminator } \\ \text { HEPA } & \text { high-efficiency particulate air } \\ \text { HLW } & \text { high-level liquid waste } \\ \text { HSS } & \text { hydrosonic scrubber } \\ \text { HIO } & \text { tritiated water } \\ \text { HNAC } & \text { heating, ventilation, and cooling } \\ \text { HWP } & \text { Hanford Waste Vitrification Plant } \\ \text { LFCM } & \text { liquid-fed ceramic melter } \\ \text { MOG } & \text { melter off gas } \\ \text { OGC } & \text { off-gas condenser } \\ \text { OCCT } & \text { off-gas' condensate tank } \\ \text { FNL } & \text { Pacific Northwest Laboratory } \\ \text { POG } & \text { process off gas } \\ \text { PSAR } & \text { Preliminary Safety Analysis Report } \\ \text { PSCM } & \text { pilot-scale ceramic melter } \\ \text { PVV } & \text { process vessel ventilation } \\ \text { RCD } & \text { reference conceptual design } \\ \text { RCT } & \text { recycle collection tank } \\ \text { REDOX } & \text { average oxidation state } \\ & \end{array}$




$\begin{array}{ll}\text { SAS } & \text { steam-atomized scrubber } \\ \text { SBS } & \text { submerged-bed scrubber } \\ \text { SCFM } & \text { standard cubic feet per minute } \\ \text { SMECT } & \text { slurry mix evaporator condensate tank } \\ \text { SRS } & \text { Savannah River Site } \\ \text { WS } & \text { vessel ventilation system } \\ \text { WWP } & \text { West Valley Demonstration Project }\end{array}$




\section{CONTENTS}

SUMMARY

ACRONMIS AND ABBREVIATION . . . . . . . . . . . . . . . V v

1.0 INTRODUCTION . . . . . . . . . . . . . . . . . . . . . 1

2.0 OFF-GAS EFFLUENT EMISSION ABATEMENT PERFORMANCE . . . . . . . . 3

2.1 LFCM PROCESS DESCRIPTION . . . . . . . . . . . . 3

2.2 LFCM EFFLUENT EMISSION CHARACTERISTICS . . . . . . . . . 5

2.2.1 Gaseous Emission .............. . 6

2.2.2 Aerosol Emission ............... 11

2.2.3 Melter Emission Performance . . . . . . . . 17

2.2.4 Emissions During Melter Idling . . . . . . . 22

2.3 LFCM OFF-GAS PROCESSING REQUIREMENTS . . . . . . . . . . . 27

2.3.1 Primary Scrubbers . . . . . . . . . . . 30

2.3.2 High-Efficiency Aerosol Scrubbers . . . . . . 43

2.4 PROCESS VESSEL VENT SYSTEM . . . . . . . . . . . . 56

2.5 BASES FOR PROCESS OFF-GAS SYSTEM EVALUATIONS . . . . . . . 58

2.5.1 Performance Evaluation . . . . . . . . . 58

2.5.2 Feed Composition ................ 59

2.5.3 Melter and Off-Gas Performance ......... 60

2.6 ASSESSMENT OF POG SYSTEM PERFORMANCE . . . . . . . . . . 65

2.6.1 Normal Radioactive Emissions . . . . . . . . 65

2.6.2 Off-Normal Emissions ............. 69

2.6.3 Conclusion ................. 73

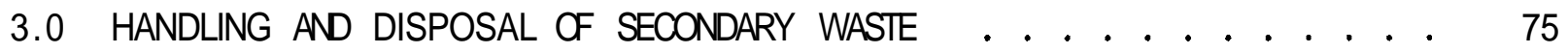

3.1 EMISSION CONTROLTECHNOLOGIES . . . . . . . . . . . . 76 
3.1.1 Relevant HWVP Guidelines . . . . . . . . . . 76

3.1.2 Off-Gas Treatment Systems . . . . . . . . . 77

3.2 SECONDARY WASTE GENERATION . . . . . . . . . . . . . . . 87

4.0 OFF-GAS SYSTEMS ENERGY ANALYSIS . . . . . . . . . . . . 95

5.0 REFERENCES ........................ 103

APPENDIX A: SIMULANTS AND SUBSTITUTIONS . . . . . . . . . . . A.I

APPENDIX B: ASSUMPTIONS AND BASES FOR ENERGY ANALYSIS . . . . . . . . B.I 


\section{FIGURES}

1 Liquid-Fed, Joule-Heated Ceramic Melter System . . . . . . . . . 3

2 Melter Exhaust Gas Composition of a 100-h Boosted.

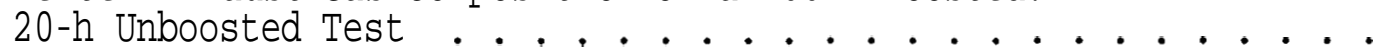

3 Compositional Behavior of Noncondensible Melter Exhaust Gases Accompanying a Flow Surge . . . . . . . . . . . . . . . .

4 Noncondensible Off-Gas Composition Preceding and During Melter Reboil

Compositional Behavior of Exhaust Stream Upon Feed Interruption

6 Melter Off-Gas Compositional Behavior Associated with Feed Termination ... . . . . . . . . . . . . .

7 Melter Off-Gas Emission Characteristics . . . . . . . . . . . .

8 Cesium Off-Gas Emissions During and After Processing a High Cesium-Bearing Feed

9 Emission Rates of Semivolatile El ements During. Melter Idling . . . . . . . . . . . . . . . . . . . 26

10 DWPF Process Off-Gas System . . . . . . . . . . . 28

11 WVDP Process Off-Gas System . . . . . . . . . . . . 29

12 HWVP Process Off-Gas System . . . . . . . . . . . . . . . 30

13 Principle of Operation of Ejector-Venturi Scrubber . . . . . . . . 31

14 Principle of Operation of Submerged-Bed Scrubber , . . . . . . . 32

15 Typical Particulate Removal Efficiencies for Type 7014 Ejector Venturi Scrubbers . . . . . . . . . . . . . . . . 34

16 Influence of Steam on SBS Performance . . . . . . . . . . 35

17 Strontium Concentrations in Melter and SBS Off-Gas Steams During Processing and Idling . . . . . . . . . . . . . . . . 40

18 Principle of Operation of Hydro-Sonic Scrubber . . . . . . . . . . 44 
Schematic of High-Efficiency Mist Eliminator Used in

PNL's PSCM Off-Gas System

Inlet and Outlet Particle Size Distributions Measured

Using Optical and Diffusional Techniques

Fractional Efficiency of the Lone Star Steel

Steam-Hydro Scrubber

Fractional Efficiency Calculated Using Impactor

Data Only . . . . . . . . . . . . . . . . . . . .

Col lector Efficiency Comparisons of Various Aerosol

Scrubbers by Particle Size

Size Distribution of Off-Gas Aerosols as Collected on

Cascade Impactor Stages in SBS and HEME Exhaust Streams . . . . $\quad \mathbf{5 3}$

25 Off-Gas Film Cooler . . . . . . . . . . . . . . . . 79

26 Submerged-Bed Scrubber . . . . . . . . . . . . . 80

27 DWPF Process Vessel Vent Filter . . . . . . . . . . . . . . 86 


\section{$\underline{\text { TABLES }}$}

1 LFCM Effluent Categories .............. 6

2 Melter DFs for Particulate and Total Feed Components Using Formated Melter Feed . . . . . . . . . . . . 13

3 Size Distribution of Metter Aerosols ........... 14

4 Typical Elemental Distribution Across the Cyclonic Sampling System ................ 15

5 Composition of $16-\mu$ m Cyclonic Sample Fraction . . . . . . 16

6 Melter Performance Under Various Processing Conditions . . . . 18

7 Steady-State Aerosol Emission Characteristics ......... 19

8 Melter Performance as a Function of wt\% Chlorine . . . . . . . 22

9 Aerosol Characteristics Exiting Quench Scrubbers . . . . . 35

10 Volatile and Nonvolatile Quench Scrubber DFs . . . . . . . 36

11 Melter and Quench Scrubber Responses to a Processing Upset ...................... 37

12 Quench Scrubber Response to an Air-Driven Off-Gas Line Film Cooler . . . . . . . . . . . . . 38

13 Quench Scrubber Performance as a Function of Scrub Liquor Concentration .............. . . 41

14 Hydrosonic DFs . . . . . . . . . . . . . 50

15 Projected HMP Radioactive Effluent Releases . . . . . . 66

16 Projected HWVP Radioactive Effluent Releases . . . . . . . . 72

17 Off-Gas Equipment Failure Rate . . . . . . . . . . 89

18 Solid Waste Disposal . . . . . . . . . . . . . 90

19 Annual Weight of Solid Waste Generated by Off-Gas Treament Systems ................... . . 92

20 Off-Gas Equipment Decontamination Volumes . . . . . . . . 93

21 Annual Volume of Liquid Waste Generated by Off-Gas Treatment Systems 
22 Off-Gas Systems Energy Requirements and Energy Costs . . . . . 97

23 Summary of Mass and Energy Balances for Melter Off-Gassystems . . . . . . . . . . . . . . . 99 


\section{$1.0 \quad$ INTRODUCTION}

Radioactive high-level liquid waste (HLLW), a byproduct of defense nuclear fuel reprocessing activities, is currently being stored in underground tanks at several U.S. sites. Because its mobility poses significant environmental risks, HШW is not a suitable waste form for long-term storage. Thus, high-temperature processes for solidifying and isolating the radioactive components of HLW have been developed and demonstrated by the U.S. Department of Energy (DOE) and its contractors. Vitrification using liquid-fed ceramic me1ters (LFCMs) is the reference process for converting U.S. HLW into a borosilicate glass. Two vitrification plants are currently under construction in the United States: the West Valley Demonstration Project (WVDP) being built at the former West Valley Nuclear Fuels Services site in West Valley, New York; and the Defense Waste Processing Facility (DWPF), which is near completion at DOE's Savannah River Site (SRS). A third facility, the Hanford Waste Vitrification Plant (HWVP), is being designed at DOE's Hanford Site.

Although all three U.S. vitrification facilities will utilize the same basic vitrification technology, site specific reasons require that plant designs vary somewhat according to local requirements. The off-gas treatment systems used in support of the LFCM process represent one of these design differences. The purpose of this report published for DOE by Pacific Northwest Laboratory $(P N L)^{(a)}$ is to compare the performance of vitrification off-gas treatment technologies with respect to effluent emission abatement, secondary waste generation, and energy consumption as applied to the HWP plant. First, the off-gas emission characteristics of LFCMs will be described from which the functional design bases of off-gas processing requirements will be developed. The capabilities and performance of the three off-gas technologies will then be examined in relation to these processing requirements for the HWP source term. The emission abatement evaluation will then be followed by an analysis of secondary waste generation characteristics and operational energy requirements for these alternative off-gas system designs.

(a) Pacific Northwest Laboratory is operated by Battelle Memorial Institute under Contract DE-ACO6-76RLO 1830. 



\subsection{OFF-GAS EFFLUENT EMISSION ABATEMENT PERFORIMANCE}

To properly evaluate and compare vitrification off-gas system technologies, it is important to understand the nature of the LFCM vitrification process, the characteristics of the effluents generated, the functional capabilities of candidate emission abatement devices, and the bases for evaluating the alternative treatment systems. As a result, these subjects will be thoroughly developed before comparing the effluent abatement capabilities of the HWVP, DWPF, and WMP off-gas processing systems.

\subsection{WFCM PROCESS DESCRIPTION}

Joule-heated, ceramic-1ined melters form the basis of the LFCM process, which is illustrated in Figure 1. This type of glass melter, developed for

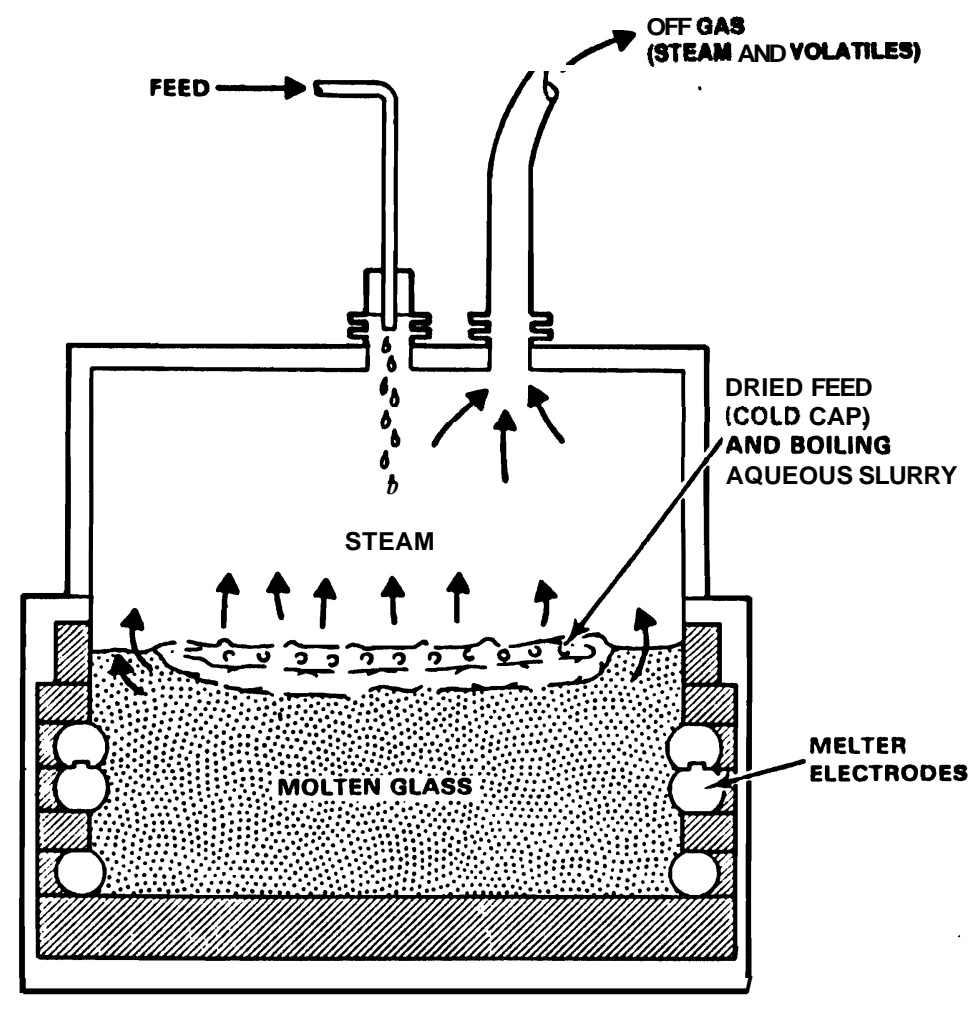

FIGURE 1. Liquid-Fed, Joule-Heated Ceramic Melter System 
the commercial glass industry, is composed of a heavily insulated, ceramic1 ined cavity that contains the molten glass, and corrosion-resistant electrodes. The power required to maintain the glass in its molten state and to process feed chemicals into more glass is supplied by electrical resistive heating produced by passing an alternating electric current (AC) through the glass pool via the immersed melter electrodes--this is known as Joule heating. Because Joule-heated ceramic melters can attain higher temperatures than conventional melters, high-silica glasses with exceptional chemical stability can be fabricated using this device. This is an important feature in LFCM applications because the vitreous waste form must exhibit low aqueous leaching rates to qualify for long-term geological storage.

Application of Joule-heated ceramic melters to the vitrification of HLLW is a straightforward extension of glass-making technology; the waste components are treated merely as a subset of chemicals needed to produce a specified glass product. In the LFCM process, major glass-forming chemicals and/or glass frit are mixed with the HLLW stream to produce an aqueous slurry that is continuously fed to the Joule-heated melter to produce a molten radioactive glass. The molten melter glass product, which commonly has a waste loading of $25 w t \%$, is transferred, via an overflow port, to metal canisters that are subsequently cooled and then sealed to further isolate the immobilized waste form.

To fully understand the functional requirements of the off-gas system supporting this process, the dynamics of the slurry glass-making operations need to be discussed. Conversion of aqueous slurry to a vitreous product takes place in three distinct steps: the slurry is dried, calcined foxidized), and then melted to form glass. During continuous feeding a "cold cap" forms within the melter that covers a large portion of the glass surface. The composition of this cold cap varies from slurry, on the cold cap surface, to multi-component calcine at the cold cap/glass interface. Because this is a continuous process, the steam and volatile reaction and decomposition products formed during the first two steps need to be continuously removed from the melter cavity by the melter off-gas (MOG) system. 
Although the evaporation and calcination processes occur continuously, their instantaneous rates vary over a rather large range. This is because the cold cap structure is not dynamically stable (although, at steady state, its average size is) and aqueous slurry often flows out onto hot glass surfaces to produce flashes of steam and gaseous oxides. The turbulence that results often hurls feed and glass material up into the melter plenum (the melter vapor space above the glass pool), where it can become entrained in gas currents and lost to the process exhaust. In addition to the gaseous and

entrainment losses associated with LFCM processing, fume or smoke generation resulting from high-temperature $\left(1050^{\circ} \mathrm{C}\right)$ vol atilization and rapid condensation is also a significant loss mechanism associated with an important class of sl urry components known as the semivolatiles.

The characteristics and the relative importance of each of these LFCM effluent loss mechanisms are discussed in the following section in terms of major chemical and radiological components of HLLW.

\subsection{LFCM EFFLUENT 'EMISSION CHARACTERISTICS}

Emission characteristics of LFCMs are normally discussed in terms of the three main effluent categories: 'gases, semivolatiles, and non vol atiles. Common LFCM effluent elements and compounds that fall into these categories, as well as some important radioactive isotopes associated with them, are identified in Table 1. ' Aerosol emission is responsible for LFCM processing losses of both semi-and nonvolatile waste components. However, the nature of the aerosols generated by these two effluent classes is so different that the members of each group place unique and distinctive processing requirements upon the LFCM off-gas treatment system, as will be discussed in subsequent sections.

Although the above categorization is fairly representative of average LFCM effluent behavior, it is not rigorously correct; most elements can exhibit properties of more than one effluent class, depending on the chemistry occurring in the cold cap and in the plenum. For example, Ru can exhibit volatile, semivolatile, or nonvolatile behavior, according to whether the 
TABLE 1. LFCM Effluent Categories

\begin{tabular}{|c|c|c|c|}
\hline & Gases & Semivolatiles & Nonvolatiles \\
\hline & $\mathrm{H}_{2}\left({ }_{3} \mathrm{H}\right)$ & $\operatorname{Cs}\left({ }^{137} \mathrm{Cs}\right)$ & A1 \\
\hline & $\mathrm{O}_{2}$ & $\mathrm{Cd}\left({ }^{115 \mathrm{~m}} \mathrm{Cd}\right)$ & $\mathrm{Fe}\left({ }^{55} \mathrm{Fe}\right)$ \\
\hline & $\cos \left({ }^{14} \mathrm{C}\right)$ & $\mathrm{Hg}$ & $\mathrm{Si}$ \\
\hline & $\mathrm{CO}_{2}\left({ }^{14} \mathrm{C}\right)$ & $\mathrm{Ru}\left({ }^{186} \mathrm{Ru}\right)$ & $\operatorname{Sr}\left({ }^{98} S r\right)$ \\
\hline & NO & $\mathrm{Sb}\left({ }^{125} \mathrm{Sb}\right)$ & Zr \\
\hline & $\mathrm{NO}_{2}$ & $\mathrm{Se}$ & Rare earths $\left({ }^{155} \mathrm{Eu}\right)$ \\
\hline & $\mathrm{SO}_{2}$ & $\mathrm{Tc}\left({ }^{99} \mathrm{Tc}\right)$ & $U^{(a)}\left({ }^{238} U\right)$ \\
\hline & $\mathrm{H}_{3} \mathrm{BO}_{3}$ & $\mathrm{Te}$ & $\mathrm{Pu}^{(\mathrm{a})}\left({ }^{239} \mathrm{Pu}\right)$ \\
\hline & $\mathrm{H}_{2} \mathrm{O}\left({ }^{3} \mathrm{H}\right)$ & Hal ides $\left({ }^{129} 1\right)$ & Transuranics ${ }^{(a)}\left({ }^{241} A m\right)$ \\
\hline & $\begin{array}{l}\mathrm{X}_{2}\left({ }^{129} \mathrm{I}\right) \\
\mathrm{HX}\left({ }^{129} \mathrm{I}\right)\end{array}$ & $\mathrm{Ni}\left({ }^{63} \mathrm{Ni}\right)$ & Many others \\
\hline
\end{tabular}

(a) Assumed behavior--LFCM experimental data lacking.

melter feed is strongly oxidizing, reducing, or strongly reducing, respectively. Silicon and uranium, both classic nonvolatiles, can, in principle, be volatilized from the cold cap under certain melter conditions when a fluoridecontaining feed is being processed. Whether these volatiles persist or react and/or condense (vol atile or semivol atile behavior) depends on cold-cap and plenum chemistry--temperature and compositional conditions. The following detailed discussion of LFCM off-gas effluent emission characteristics covers the DWPF, WVDP, and HWVP processes.

\subsubsection{Gaseous Emission}

The effluent gases evolved during melter processing are primarily caused by the presence of chemical additives used in waste processing $\left(\mathrm{H}_{2} \mathrm{O}, \mathrm{NO}_{3}^{-}\right.$, and $\mathrm{SO}_{4}{ }^{2}$ ) or in feed conditioning (water, boron oxide, and organics). Because boron, carbon, hydrogen, nitrogen, and sulphur all possess a variety of volatile compounds, melter exhaust composition will vary depending on the nature of the feed stream, melter inleakage, plenum temperature, and the chemical forms of the effluents in the feed. 
The chemical properties of the feed component elements and their slurrybased compounds are very influential in establishing relative proportions of the various gaseous byproducts produced during LFCM feed processing. This fact is illustrated by the behavior of carbonaceous reductants in the feed. When formic acid is used in LFCM feeds, flammability hazards associated with $\mathrm{H}_{2}$ and $\mathrm{CO} \mathrm{in}$ the quenched melter exhaust become a process concern that needs to be addressed. The combustibility hazard associated with the use of formic acid is dependent upon the concentration of free acid present. Reaction with basic oxides to form metal formates not only increases the effectiveness of the formic acid as a reductant but also dramatically reduces hydrogen generation rates during vitrification. The use of equivalent quantities of a more thermally and chemically stable reductant, such as sugar, cornstarch, oxalic acid, and/or coal, has also been sucessfully used to li mit combustible gas generation rates and eliminate combustibility hazards. Of course, other operational parameters, such as plenum temperature and melter inleakage, can also be used to influence melter exhaust gas composition. The use of Iid heaters in the vapor space above the glass melt (the plenum) which are employed to increase or "boost" processing rates have been shown to be quite effective in oxidizing gaseous combustibles before they are conveyed into the off-gas system.

The effect of plenum lid heaters upon the melter exhaust composition is illustrated in Figure 2, which characterizes results from a PNL melter test conducted in support of the DWPF (Goles and Sevigny 1983a). This test employed $100 \mathrm{~h}$ of radiant $\mathrm{lid}$ heat boosting, followed by $20 \mathrm{~h}$ of unboosted operation. The high plenum temperatures associated with lid heating have a definite controlling influence on the combustible gases $\mathrm{CO}$ and $\mathrm{H}_{2}$. The data presented in this figure also illustrate that melter emissions are not gener ated smoothly or continuously even under the most controlled operational conditions. This behavior is a result of the nonuniform way in which melter feed is dried, oxidized, and melted during the liquid feeding process. Variations in melter gas generation rates (surging) usually occur when dammed-up liquid feed lying atop an insulating layer of dry feed (the cold cap) abruptly flows out upon a hot glass surface. The liquid quickly flashes off this hot 


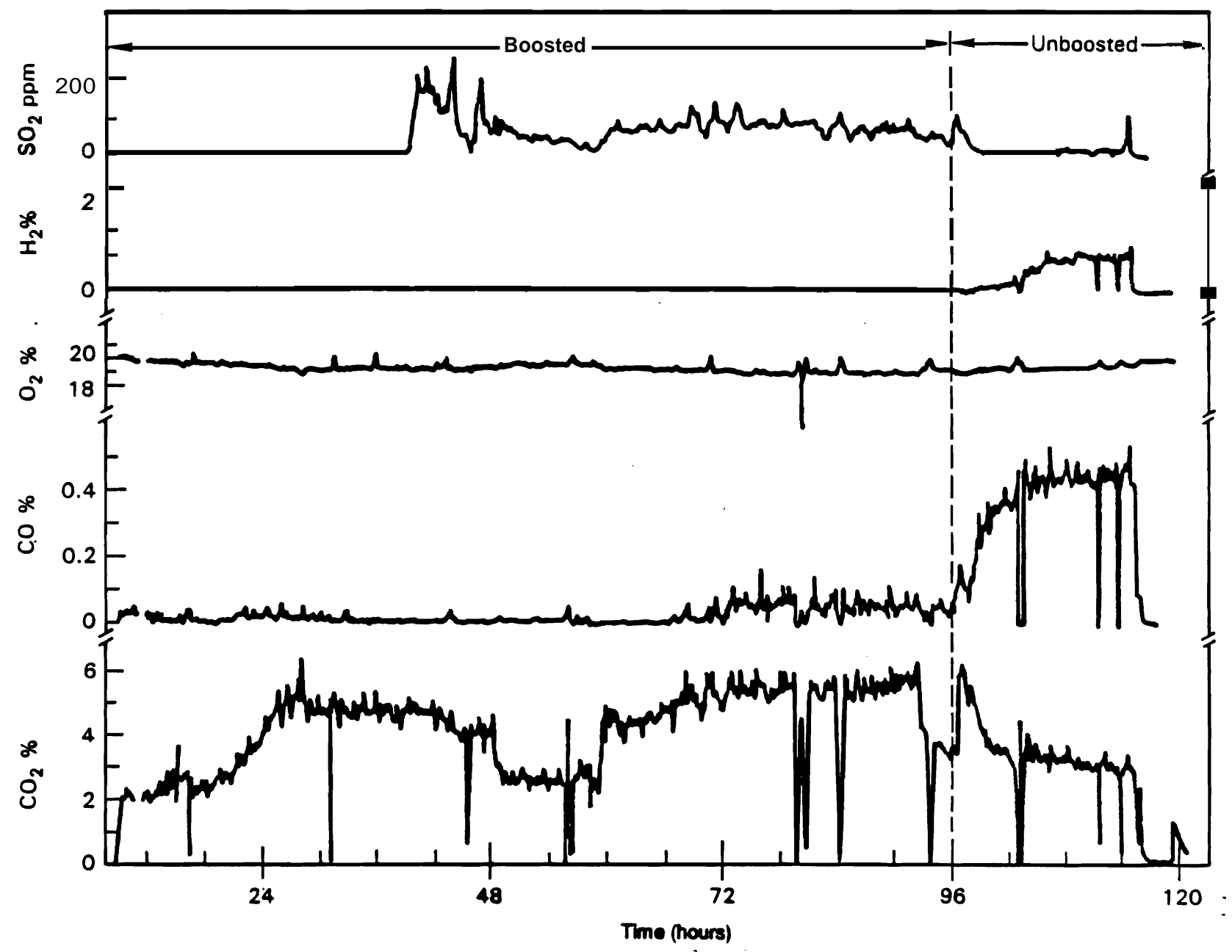

FIGURE 2. Melter. Exhaust Gas Composition of a 100-h Boosted, 20-h Unboosted Test (Goles and Sevigny 1983a)

surface, producing a flow pulse composed of steam and volatile decomposition/ reaction products. The frequency and/or extent of these excursions is related to the physical properties of the feed which, in turn, are compositiondependent. Figures 3 and 4 illustrate the behavior of some of the more important melter-generated gases accompanying flow surges. The frequency and magnitude of these surges are positive indicators of melter system instabilities, which are most often associated with nonuniform or excessive feeding. One of the instabilities is reboil (see Figure 4), which is caused by rapid oxidation state changes in glass components and involves rapid evolution of oxygen from the glass pool. 


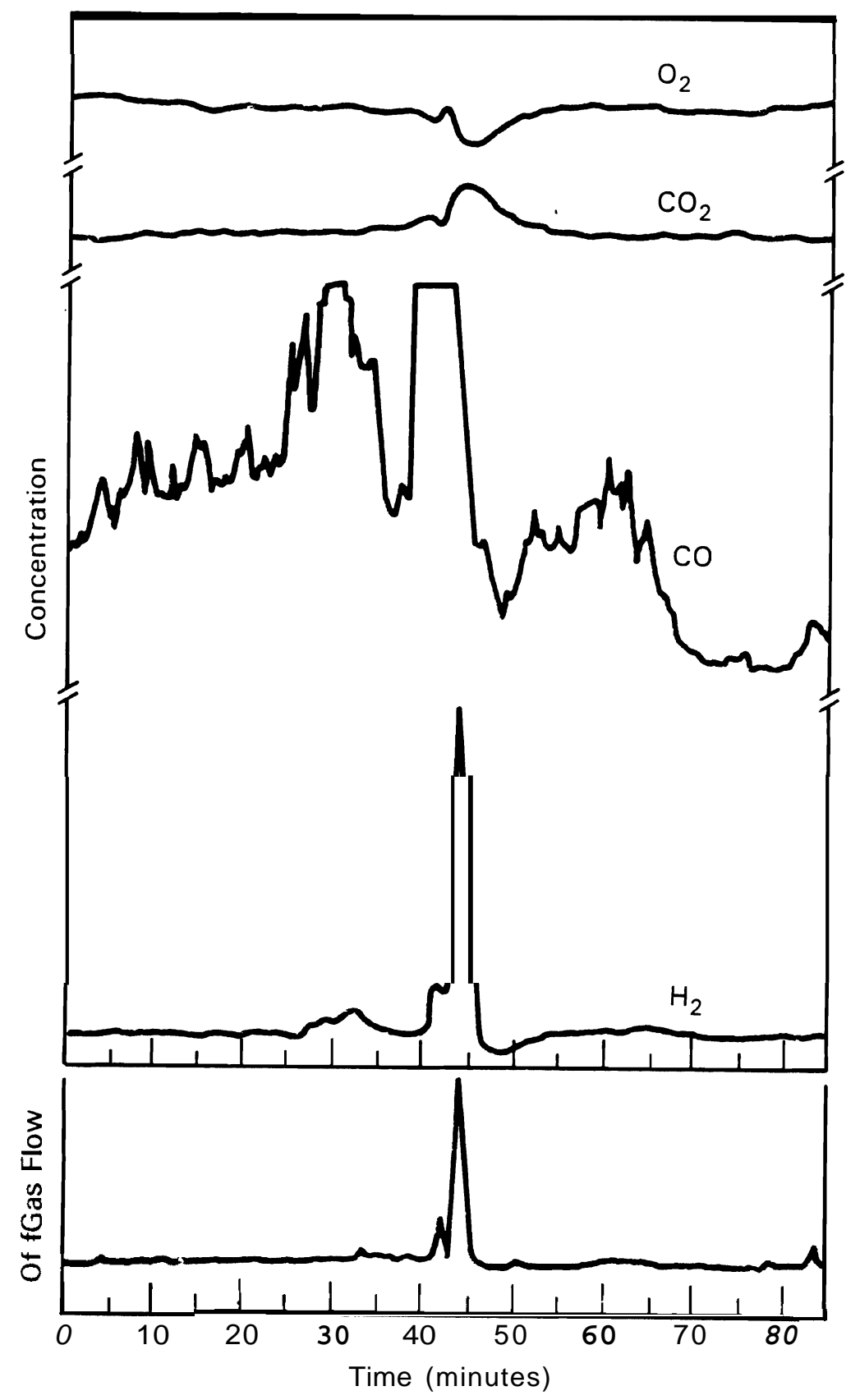

FIGURE 3. Compositional Behavior of Noncondensible Melter Exhaust Gases Accompanying a Flow Surge. (Maximum extend of the surge event: flow $=3 \mathrm{X} ; \mathrm{H}_{2}<3.5 \% ; \mathrm{CO} \gg 0.5 \% ; \mathrm{CO}_{2}=15 \% ; \mathrm{O}_{2}=17 \%$ ) (Goles and Sevigny 1983a) 


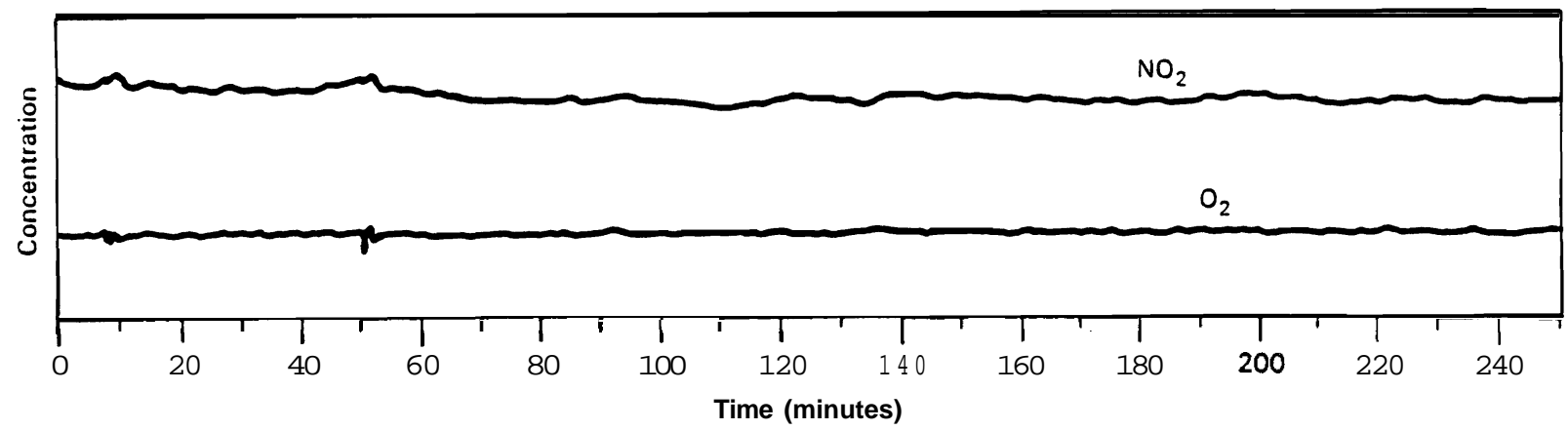

Interval Preceeding Reboil

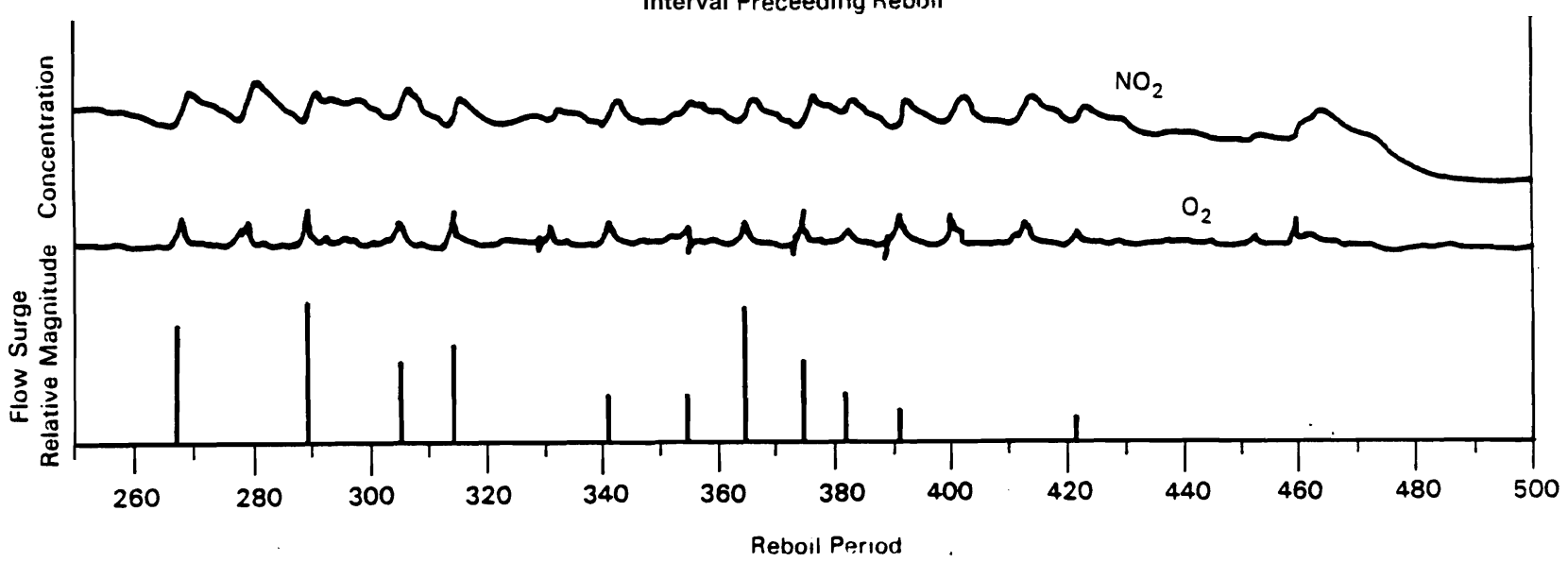

FIGURE 4. Noncondensible 'off- as Composition Preceding and During Melter Reboil (Scott, Goles, and Peters 1985)

The correlation between the emission rates of noncondensible gases and steam flow surges suggests a prompt evolution of combustible gases from the cold cap. Figures 5 and 6 portray the time-dependent compositional behavior of the melter exhaust streams upon feed interruption or termination. With the exception of $\mathrm{SO}_{\prime}$, none of the melter-generated gases increased in concentration when feeding was terminated. Consequently, a dry cold cap has not been observed to produce combustibility hazards that are greater than those already existing during normal liquid feeding.

Other chemical additives such as the halogens are also evolved predominantly as gases in the DWPF, WVDP, and HWVP processes. Mercury, a significant chemical component in SRS defense waste, has been found in PNL studies (Goles, Sevigny, and Andersen 1990) to be strongly (>>50\%) volatilized from LFCMs as 


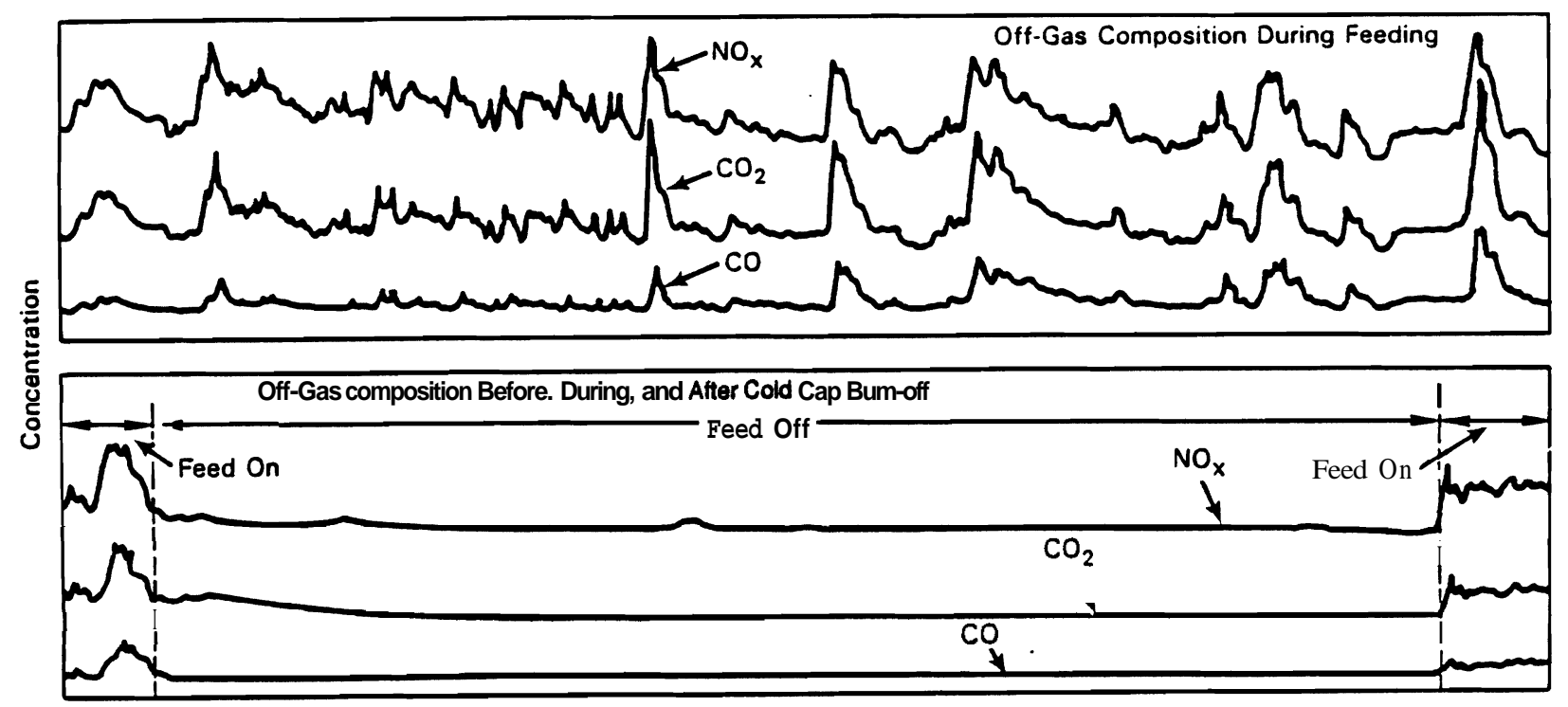

Time $\rightarrow$

FGURE 5. Compositional Behavior of Exhaust Stream Upon Feed Interruption (Scott, Goles, and Peters 1985)

mercurous halides, while only $1 \%$ of boron, a common glass-forming additive in a11 three processes, volatilizes as $\mathrm{H}_{3} \mathrm{BO}_{3}$ during LFCM feed processing. 'The greatest volumetric contributor to LFCM gaseous emissions is of course steam, which is generated from the water content of the slurry feed.

The radiological impact of LFCM gaseous effluent losses is primarily due to the presence of ${ }^{3} \mathrm{H},{ }^{14} \mathrm{C}$, and ${ }^{129} \mathrm{I}$ in HLLW. Because the vitreous product has a negligible capacity for hydrogen and carbon, essentially all ${ }^{3} \mathrm{H}$ and ${ }^{14} \mathrm{C}$ in the melter feed stream is lost to the off-gas processing system as steam (tritiated water, HTO) and as oxides of carbon $\left({ }^{14} \mathrm{CO}_{\mathrm{x}}\right)$, respectively. Simi larly, large process losses of iodine $(>50 \%)$ have been observed (Perez and Nakaoka 1986) due to the volatility of its elemental and chemically combined forms. Since the glass capacity for iodine is expected to be quite low, process models usually assume 100\% volatility losses for this element.

\subsubsection{Aerosol Emission}

From the previous discussion it is quite clear that LFCM gaseous effluent losses are limited to only a very few waste components, and of these only 


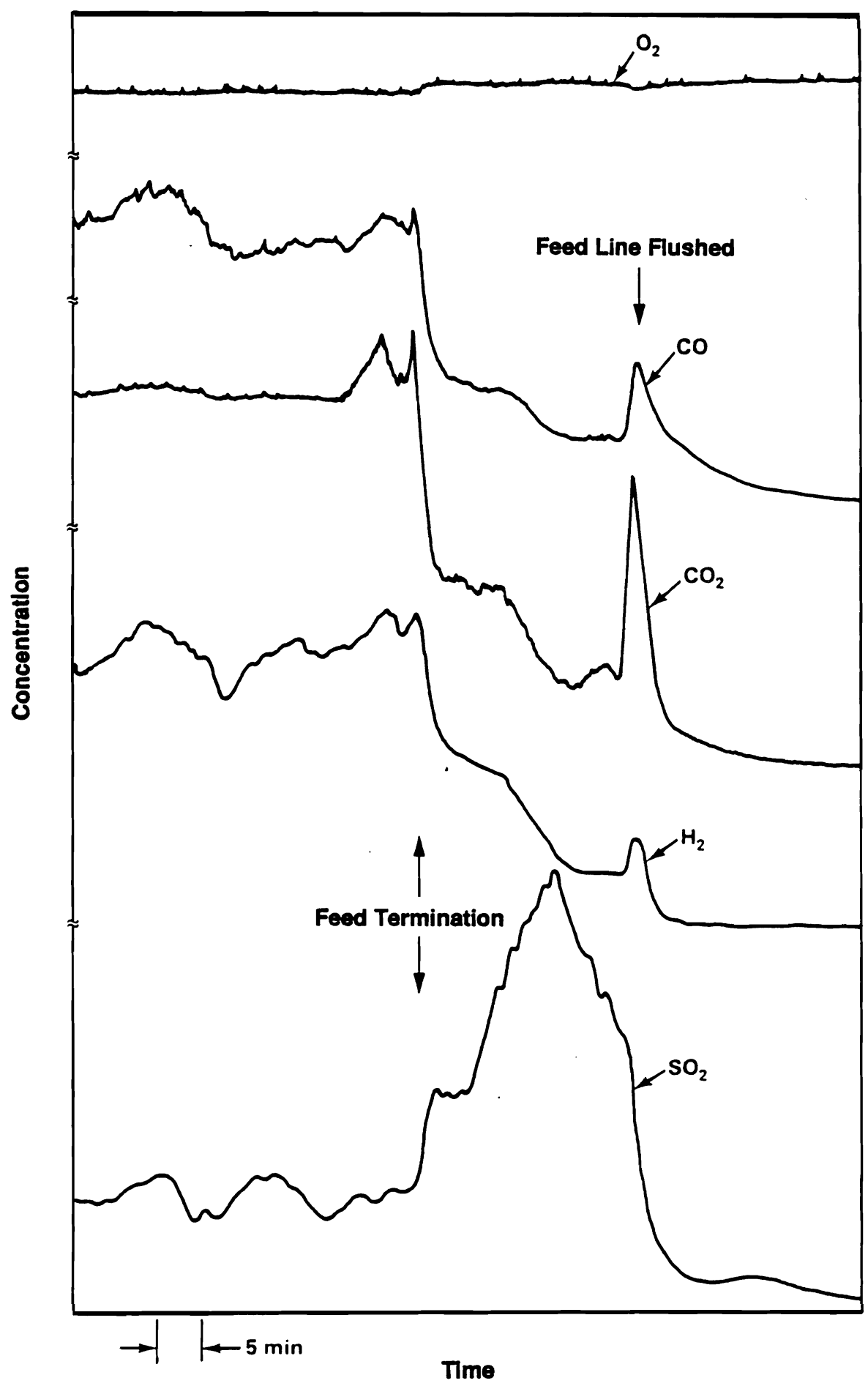

FIGURE 6. Melter Off-Gas Compositional Behavior Associated with Feed Termination. (The compositional spike after feed termination is due to the injection of a small quantity of liquid feed.) (Goles and Sevigny 1983a) 
hydrogen $\left({ }^{3} \mathrm{H}\right)$ and carbon $\left({ }^{14} \mathrm{C}\right)$ are exclusively lost by this escape mechanism. The loss rates of essentially all other melter feed components are influenced, to a greater or lesser extent, by aerosol (airborne particulate) escape. This fact is clearly illustrated in Table 2, which summarizes typical LFCM off-gas emission data. The values listed in this table are melter decontamination factors (DFs), which are ratios of the rate at which feed components enter the melter to the rate at which they are evolved. Particulate DFs are partial DFs relating to only a single loss mechanism: aerosol emission. The data presented in this abridged table clearly show that melter gas-phase losses to the off-gas system are only significant for $\mathrm{Cl}, \mathrm{S}$, and $\mathrm{B}$, which readily form volatile acid gases as previously discussed.

Melter-induced volatilization also influences IFCM loss rates of another class of waste components, which quickly react or condense in the melter plenum to form airborne particulate effluent. The low DFs associated with the semivolatile elements $\mathrm{Cd}, \mathrm{Cs}$, and $\mathrm{Te}$, as well as Se and $\mathrm{Sb}$, underscore the importance of this volatilization process. However, Table 2 clearly shows

TABLE 2. Melter DFs for Particulate and Total Feed Components Using Formated Melter Feed (Goles and Sevigny 1983a)

\begin{tabular}{|c|c|c|}
\hline \multirow[b]{2}{*}{ Element } & \multicolumn{2}{|c|}{ Average DF } \\
\hline & Particulate & Total \\
\hline A1 & 27,000 & 22,000 \\
\hline B & 6,800 & 100 \\
\hline $\mathrm{Cd}$ & 9.9 & 9.9 \\
\hline $\mathrm{Cl}$ & 21 & 2.9 \\
\hline Cs & 14 & 14 \\
\hline $\mathrm{Fe}$ & 1,900 & 1,800 \\
\hline La & 2,100 & 2,100 \\
\hline $\mathrm{Mn}$ & 1,800 & 1,800 \\
\hline $\mathrm{Na}$ & 300 & 300 \\
\hline$S$ & 11 & 5.5 \\
\hline$S r$ & 1,800 & 1,800 \\
\hline Te & 3.0 & 3.0 \\
\hline $\mathrm{Zr}$ & 22,000 & 22,000 \\
\hline
\end{tabular}


that, apart from the mechanisms producing these airborne effluents, aerosol emission is responsible for off-gas system losses of these effluents. Transport of airborne particulate matter through the off-gas system is the predominant LFCM loss mechanism for radioactive waste components.

Because most radiological melter off-gas system losses involve aerosol emission, establishing the characteristics of these aerosols is particularly important to off-gas system design. The size distribution of melter-generated aerosols has been established at PNL using a cyclonic particle-size analysis system. Table 3 details the characteristic manner in which melter particulate matter is found to be distributed across the cyclonic sample fractions for various pilot-scale melter experiments conducted with DWPF, WDP, and HWVP simulated feed streams. All melter tests, in general, exhibited aerosol-size distributions that were bimodal. This result suggests that the overall aerosol effluent size distribution is composed of two independent components, each having its own characteristic size distribution. Gross compositional dissimilarities between the discrete cyclonic size fractions shown in Table 4

TABLE 3. Size Distribution of Melter Aerosols

PNL Experiment No.

LFCM-7

PSCM-4

PSOM-5

PSCM-6

PSCM-7

PSCM-8

PSCM-9

PSCM- 15

PSCM-20

PSCM-23
Feed Type

Formate DWPF

Formate DWPF

Formate DWPF

Formate DWPF

Formate DWPF

Formate DWPF

Nitrate WMP

Nitrate WDP

High Cs WMP

Formate HWP
Average' $w t \%$

$\begin{array}{rrrr}? \frac{16 \mu \mathrm{m}}{16} \rightarrow \frac{6 \mu \mathrm{m}}{2.8} & -\frac{1}{1} \mu \mathrm{m} & & \frac{\leq 1 \mu \mathrm{m}}{11.9} \\ 76.7 & 2.8 & 8.5 & 11.9 \\ -- & 0.9 & 3.6 & 95.6 \\ 13.5 & 3.9 & 20.2 & 62.2 \\ 46.1 & 0.5 & 12.7 & 40.7 \\ 7.5 & 3.2 & 9.4 & 79.9 \\ 44.0 & 7.3 & 19.6 & 29.1 \\ 8.2 & 2.1 & 16.3 & 73.7 \\ 44.7 & 9.8 & 22.4 & 23.1 \\ 1.7 & -- & 12.5 & 85.8 \\ 29.6 & 5.2 & 18.8 & 46.4\end{array}$

(a) $\quad P S C M=$ pilot-scale ceramic melter .

-- Indicates data below detection limit. 
TABLE 4. Typical Elemental Distribution Across the Cyclonic Sampling System (Gol es and Sevigny 1983a)

\begin{tabular}{|c|c|c|c|c|}
\hline & \multicolumn{4}{|c|}{ Distribution (\%) } \\
\hline Element & $16 \mu \mathrm{m}$ & $6 \mu \mathrm{m}$ & $1 \mu \mathrm{m}$ & $\leq 1 \mu \mathrm{m}$ \\
\hline A1 & 96.2 & 0.9 & 2.5 & 0.4 \\
\hline B & 87.8 & 1.8 & 7.8 & 2.6 \\
\hline $\mathrm{Ba}$ & 83.7 & 5.8 & 10.5 & 0 \\
\hline $\mathrm{Ca}$ & 77.7 & 2.7 & 15.2 & 4.4 \\
\hline $\mathrm{Cd}$ & 10.7 & 0.8 & 7.9 & 81.2 \\
\hline $\mathrm{Ce}$ & 92.1 & 0 & 7.9 & 0 \\
\hline $\mathrm{Cr}$ & 46.4 & 21.7 & 23.3 & 8.6 \\
\hline Cs & 7.5 & 0 & 5.4 & 87.1 \\
\hline $\mathrm{Cu}$ & 82.6 & 4.9 & 4.2 & 8.3 \\
\hline $\mathrm{Fe}$ & 77.3 & $2.6^{\circ}$ & 7.0 & 3.1 \\
\hline La & 91.9 & 1.5 & 6.1 & 0.5 \\
\hline Li & 83.2 & 1.5 & 5.3 & 10.0 \\
\hline $\mathrm{Mg}$ & 91.5 & 1.6 & 5.8 & 1.1 \\
\hline$M n$ & 89.4 & 6.4 & 3.6 & 0.6 \\
\hline Mo & 77.5 & 5.6 & 9.8 & 7.1 \\
\hline $\mathrm{Na}$ & 68.8 & 1.7 & 5.6 & 23.9 \\
\hline $\mathrm{Nd}$ & 93.4 & 0 & 6.6 & 0 \\
\hline $\mathrm{Sb}$ & 100.0 & 0 & 0 & 0 \\
\hline $\mathrm{Se}$ & 56.9 & 1.9 & 11.4 & 29.8 \\
\hline $\mathrm{Si}$ & 92.0 & 1.8 & 5.6 & 0.6 \\
\hline $\mathrm{Sr}$ & 77.6 & 2.8 & 19.6 & 0 \\
\hline $\mathrm{Te}$ & 5.5 & 0.4 & 3.2 & 90.9 \\
\hline $\mathrm{Ti}$ & 91.2 & 1.8 & 6.0 & 1.0 \\
\hline $\mathrm{Zr}$ & 91.6 & 1.6 & 5.6 & 1.2 \\
\hline
\end{tabular}

strongly reinforce this argument. Moreover, because the submicron-size fraction shown in this table (LFCM-7) contains only $12 \%$ of the total sample mass but possesses essentially all the semivolatile matter of the sample, the mechanism responsible for the small-diameter component of the overall distribution is probably a volatilization/condensation process that occurs within 
the melter plenum. The compositions of the large cyclonic size fractions are very similar to those of the slurry feed, as shown in Table 5. Consequently, the large component of the bimodal distribution is most certainly associated with a gross entrainment mechanism.

Because, on the average, greater than $50 \%$ of the LFCM particulate offgas system losses are associated with aerosols having aerodynamic di ameters of $1 \boldsymbol{\mu m}$ and less, and because essentially all the radiologically important semivolatiles are concentrated in these fractions, melter design parameters such as plenum freeboard and exhaust port and feed nozzle positioning have 1ittle or no effect on off-gas processing design criteria. TABLE 5. Composition of 16- $\mu$ m Cyclonic Sample Fraction
(Goles and Sevigny 1983a)

\begin{tabular}{|c|c|c|}
\hline Ell ementag 1 & \multicolumn{2}{|c|}{ Weight Percent } \\
\hline Oxides $^{(a)}$ & $16 \mathrm{~mm}$ & Feed \\
\hline $\mathrm{Al}_{2} \mathrm{O}_{3}$ & 3.4 & 5.1 \\
\hline $\mathrm{B}_{2} \mathrm{O}_{3}$ & 9.0 & 10.5 \\
\hline $\mathrm{CaO}$ & 1.6 & 1.7 \\
\hline $\mathrm{Fe}_{2} \mathrm{O}_{3}$ & 14.4 & 12.7 \\
\hline $\mathrm{La}_{2} \mathrm{O}_{3}$ & 0.3 & 0.4 \\
\hline $\mathrm{LiO}_{2}$ & 3.5 & 4.1 \\
\hline MgO & 1.1 & 1.4 \\
\hline $\mathrm{MnO}$ & 3.2 & 2.9 \\
\hline $\mathrm{Na}_{2} \mathrm{O}$ & 13.0 & 13.6 \\
\hline $\mathrm{SiO}_{2}$ & 38.0 & 45.6 \\
\hline $\mathrm{TiO}_{2}$ & 0.7 & 0.7 \\
\hline Zro & 0.3 & 0.4 \\
\hline
\end{tabular}

(a) Assumed oxide forms. 


\subsubsection{Melter Emission Performance}

Because most melter off-gas system losses have been shown to be associated with aerosol emission, the off-gas performance (DF) of LFCMs is conveniently measured in terms of gross (total) off-gas aerosol losses. The effects of various processing variables upon melter performance have been extensively studied during cold, scaled simulation testing of the LFCM process. The affect of these variables upon melter losses are discussed below.

\section{Cold Cap Coverage}

A comparison of the average gross melter DFs obtained from the numerous melter tests conducted at PNL reveals that, irrespective of feed type, when a melter is fed conservatively (underfed with a cold cap coverage of <90\%) due to either experimental design or system limitations, extremely high glass conversion efficiencies and aerosol DFs result. Conversely, experiments punctuated by erratic or overfeeding conditions (unstable cold cap) have, in general, exhibited the poorest off-gas emission performance. Between these two extremes lie the majority of melter tests conducted at PNL, where feeding rates were carefully ramped to produce stable steady-state operating conditions that matched feeding and glass production rates at $-90 \%$ cold cap coverage. Table 6 compares emission data obtained from LFCM tests conducted under all three types of feeding conditions: conservative and steady, cold cap <90\%; steady state, -90\% cold cap coverage; and overfeeding and/or erratic, cold cap $>90 \%$.

\section{Feed Rate Boosting}

It is clear from a process engineering standpoint that a continuous steady-state feeding condition is the most desirable of the three operating alternatives. The maximum feeding rates achievable for a given melter under steady-state conditions can be and have been increased (boosted) through use of auxiliary plenum heaters. The effect of feed boosting on melter performance has been studied under controlled steady-state conditions. These tests were designed to establish the relationships, if any, between absolute feed rates and melter $\mathrm{DF}$. 
TABLE 6. Melter Performance Under Various Processing Conditions

\begin{tabular}{|c|c|c|c|}
\hline Processing Conditions & Feed Type & Test & $\mathrm{DF}$ \\
\hline \multirow[t]{3}{*}{ Conservative and Steady } & Alkaline DWPF(a) & PSCM-1 & 1100 \\
\hline & Formic DWPF(a) & PSCM-3 & 980 \\
\hline & Formic HWVP(b) & PSCM-23 & 1500 \\
\hline \multirow[t]{4}{*}{$90 \%$ Cold Cap and Steady } & Formic DWPF ${ }^{(a)}$ & PSCM-4 & 490 \\
\hline & Nitrate WVDP(c) & PSCM-9 & 460 \\
\hline & Formic HWVP(d) & HB85-1 & 430 \\
\hline & Formic HWVP(c) & PSCM-22 & 330 \\
\hline \multirow[t]{3}{*}{ Overfed and/or Erratic } & Alkaline DWPF(a) & LFCM-6 & 180 \\
\hline & Formic DWPF(a) & LFCM-7 & 120 \\
\hline & Nitrate WVDP(c) & PSCM- 16 & 160 \\
\hline
\end{tabular}

(a) Goles and Sevigny 1983a.

(b) Goles and Nakaoka 1990.

(c) Perez and Nakaoka 1986.

(d) Goles and Andersen 1986.

Table 7 presents gross aerosol DF values associated with the boosted PSCM-5 and PSCM- 6 tests. These data show no correlation between feed rates and DFs. Moreover, the boosted PSCM-6 experiment did not utilize electric radiant lid heaters for the entire melter test, yet no significant differences in normalized melter emission rates (DFs) were observed throughout the experiment. Consequently, these data suggest that the use of electric radiant plenum heaters can boost processing rates of liquid feed rates of ceramic me1ters without significantly affecting melter (DF) performance.

Air-sparge-induced glass convection has also been used to boost LFCM steady-state feed rates. The results obtained from the limited tests conducted indicate that, at worst, a slight lowering of melter DF may result because of increases in gross entrainment. These losses are, however, readily 
TABLE 7. Steady-State Aerosol Emission Characteristics

\begin{tabular}{|c|c|c|c|c|c|c|c|}
\hline $\begin{array}{c}\text { PSCM-5 } \\
\text { Sample } \\
\text { Identification }\end{array}$ & $\begin{array}{l}\text { Boost } \\
\text { Feed } \\
\text { Rate } \\
\text { (L/h) } \\
\end{array}$ & $\frac{\text { Test }}{\frac{\text { Particul }}{\text { Loading }}}$ & & $\begin{array}{c}\text { PSCM-6 Boosted } \\
\text { Sample } \\
\text { Identification } \\
\end{array}$ & $\begin{array}{l}\text { and Ur } \\
\text { Feed } \\
\text { Rate } \\
(\boldsymbol{L} / \mathbf{h}) \\
\end{array}$ & $\frac{\text { poosted T }}{\frac{\text { Particul }}{\text { Loading }}}$ & $\frac{\frac{s t}{t e}}{D F}$ \\
\hline A & 51 & 0.55 & 470 & A & 68 & 0.29 & 820 \\
\hline B & 72 & 0.49 & 460 & B & 68 & -- & 810 \\
\hline C & 79 & 0.44 & 510 & C & 67 & 0.37 & 840 \\
\hline D & 81 & 0.61 & 440 & D & 74 & 0.25 & 910 \\
\hline$E$ & 81 & -- & 370 & $E$ & 90 & 0.41 & 700 \\
\hline$F$ & 86 & 0.48 & 492 & $F$ & 91 & 0.28 & 840 \\
\hline G & 93 & 0.48 & 440 & G & 90 & -- & 720 \\
\hline$H$ & 93 & -- & 670 & $H$ & $58^{(b)}$ & 0.32 & 870 \\
\hline Overall Average & ( & - - - - & 480 & I & $58^{(b)}$ & 0.54 & 660 \\
\hline
\end{tabular}

Overall Average $-800$
(a) STP.
(b) Unboosted operation.
-- Indicates data not avai 1able.

removed by the first stage quench scrubber. The overall DF across the melter and quench scrubber has not been found to be significantly affected by forcedconvective feed rate boosting techniques.

\section{Feed Composition}

It has been shown (Table 3) that physical characteristics of LFCMgenerated aerosols are nominally independent of feed compositions. However, . the composition and magnitude of these emissions are dependent upon the physical and chemical nature of the slurry feed. Indeed, of all the parameters that can affect LFCM performance, feed composition is the most important. Ironically, the feed components that have the greatest influence on melter exhaust characteristics are traditionally chemical additives used in waste processing (nitrates, sulfates, and the halogens) or in feed conditioning 
(organics--sugar, formic acid, etc.). These chemical additives directly influence the magnitude of MOG system losses resulting from both entrainment and volatilization.

Physical Affects. There are several mechanisms by which melter entrainment is affected by feed composition. The physical ability of feed components to form a structurally sound insulating layer between the incoming feed and the hot glass surface is one of the more important factors influencing melter processing stability and, consequently, the magnitude of off-gas entrainment losses. Ideally, upon entry into an LFCM, the waste components of the slurry feed would be dried, calcined, and melted in a smooth continuous process to form a molten borosilicate glass. In reality, structural collapse of the cold cap often brings dammed-up liquid feed into contact with extremely hot glass surfaces, which results in the flashing off of steam and volatile reaction products. The nonuniform pulsed flow that results increases entrainment losses. The degree and frequency with which this occurs is a compositiondependent property of the feed. The formating of hydroxide slurry feeds has, for example, been found (Goles and Sevigny 1983a,b) to significantly improve cold cap melting and LFCM processing characteristics. On the other hand, melter glass reboil initiated by highly oxidized feeds (a chemical property) produces destabilizing effects by causing cold cap collapse. Figure 4 demonstrates the smooth and disruptive flow patterns associated, respectively, with stable and unstable melter processing (cold cap) conditions.

The importance of entrainment upon overall cesium loss rates depends upon the corresponding magnitude of cesium volatilization losses which, as will be seen, are also compositionally dependent. Since the range of melter cesium DFs is nominally an order of magnitude lower than the observed range of overall aerosol DFs, a feed possessing low volatility would have to also produce extremely high entrainment losses in order to significantly influence melter cesium DF. This has never occurred during PNL IFCM testing; however, it is certainly possible.

Chemical Affects. The influence of feed composition upon melter semivolatile losses is clearly demonstrated by the order of magnitude range in observed cesium DFs. As previously discussed (see Table 1), melter losses of 
cesium and other semivolatiles are dominated by a volatilization/condensation loss mechanism. Consequently, processing stability has little to do with observed melter cesium performance. As a result, the differences in observed cesium DFs must logically be associated with factors affecting volatilization rates. Since plenum temperature and cold cap glass coverage have been previously shown to be unrelated to cesium DF, the chemistry in the cold cap must be responsible. For most semivolatiles, including cesium and mercury, the halogen feed components appear to determine and limit volatilization rates. In most PNL tests, the halogen chlorine was introduced into the LFCM slurries as an impurity in the $\mathrm{Fe}(\mathrm{OH})_{3}$ feed component. The variability in semivolatile alkali element DFs, moreover, has been found to be directly related to the availability of chlorine in the feed stream. This of course implies that LFCM-generated emissions of the alkali elements, including cesium, are predominantly composed of chlorinated (halogenated) compounds. The fact that the chlorine (halogen) content of aerosol effluent varies directly with its alkali content strongly supports this supposition, as is shown in Table 8 (Goles and Andersen 1986).

Chemical competition for available halogens can, however, affect cesium melter DF. The presence of relatively high feed concentrations of mercury $(\mathrm{Hg}: \mathrm{Cs}=10: 1)$ have been observed to significantly increase cesium DFs (Goles, Sevigny, and Andersen 1991). Like the alkali elements, mercury exclusively forms halogenated compounds during the LFCM processing. The thermodynamics and/or kinetics of the competing reactions apparently favor the formation of halogenated mercury over that of cesium, thus limiting cesium emission rates.

Although the halogen content of LFCM feed, in combination with its chemical availability, apparently determines alkali element volatilization rates, not enough data exist to establish the exact functional relationship involved. However, this relationship, whatever form it may take, appears to be independent of the REDOX (average oxidation) state of both the feed and the glass. Cesium DFs of -10 have been observed under strongly oxidizing as well as reducing $\mathrm{LFCM}$ processing conditions where the only common factor between tests has been a highly reactive halide (chlorine) feed composition. 
TABLE 8. Melter Performance as a Function of wt\% Chlorine

\begin{tabular}{|c|c|c|c|c|}
\hline \multirow[b]{2}{*}{ PNL Test } & & \\
\hline & Cs & $\mathrm{Cl}$ & Cs & $\underline{\text { Mass }}$ \\
\hline PSCM- 5 & 2.2 & 56.7 & 9.5 & 490 \\
\hline PSCM-4 & 1.9 & 43.4 & 16 & 630 \\
\hline PSCM-7 & 1.2 & 39.0 & 13 & 870 \\
\hline $\operatorname{PSCM}-9^{(a)}$ & 2.0 & 33.1 & 14 & 460 \\
\hline PSCM-6 & 2.4 & 25.0 & 14 & 860 \\
\hline PSCM-22 & 6.1 & $>12.6^{(b)}$ & 14 & 330 \\
\hline PSCM-8 & 0.34 & 10.0 & 130 & 940 \\
\hline PSCM-21 & 0.57 & 7.2 & 33 & 200 \\
\hline PSCM-20 & 24 & 5.9 & 140 & 640 \\
\hline PSCM- $16^{(a)}$ & 0.30 & 5.1 & 59 & 160 \\
\hline PSCM- $15^{(a)}$ & 0.48 & 3.9 & 62 & 240 \\
\hline PSCM- 19 & 0.27 & 2.3 & 97 & 370 \\
\hline
\end{tabular}

(a) These tests were highly oxidizing.
(b) Equivalent halogen content.

The oxidizing properties of the slurry waste stream, which are usually established by chemical additives $\left(\mathrm{NO}_{3}{ }^{-}, \mathrm{SO}_{4}{ }^{-}, \mathrm{H} O 00 \mathrm{H}\right.$, etc.), are also quite influential in establishing the melter performance for radiologically important elements having volatile oxides. Specifically, highly oxidizing feeds and resultant glasses promote melter volatilization losses of ruthenium, technetium, and iodine isotopes. Reducing feeds, on the other hand, are found to totally suppress Ru and Tc volatility to the point that off-gas system losses are established by physical entrainment escape mechanisms. This has not been true for iodine, however.

\subsubsection{Emissions During Melter Idling}

When an LFCM is not processing slurry feed, it is said to be idling. To establish the importance of idling upon the overall melter source term, effluent emission characteristics associated with the idling state have been extensively studied at PNL (Goles and Sevigny 1983a,b). If the idling state is 
considered to begin when liquid slurry feeding is terminated, the melter source has both short- and long-term emission characteristics, which are graphically displayed in Figure 7. With an unboosted melter, cesium as well as overall emission rates decrease rapidly as the existing cold cap is consumed. Once the cold cap has dissolved, the melter plenum temperature (without 1 id heaters) begins to increase over several days from a processing condition of $-200^{\circ} \mathrm{C}$ to a steady-state value of $1000^{\circ} \mathrm{C}$. During this period, feed deposits on the plenum surfaces, which are enriched in semivolatiles, burn away and produce the peak in idling emission rates that is most pronounced for the semivolatile elements, especially cesium. The pulsed emission characteristics of individual feed components are determined solely by their semivolatile nature. Consequently, two distinct sets of plenum burn-off peaks are observed, which are associated with semivolatiles or nonvol atiles.

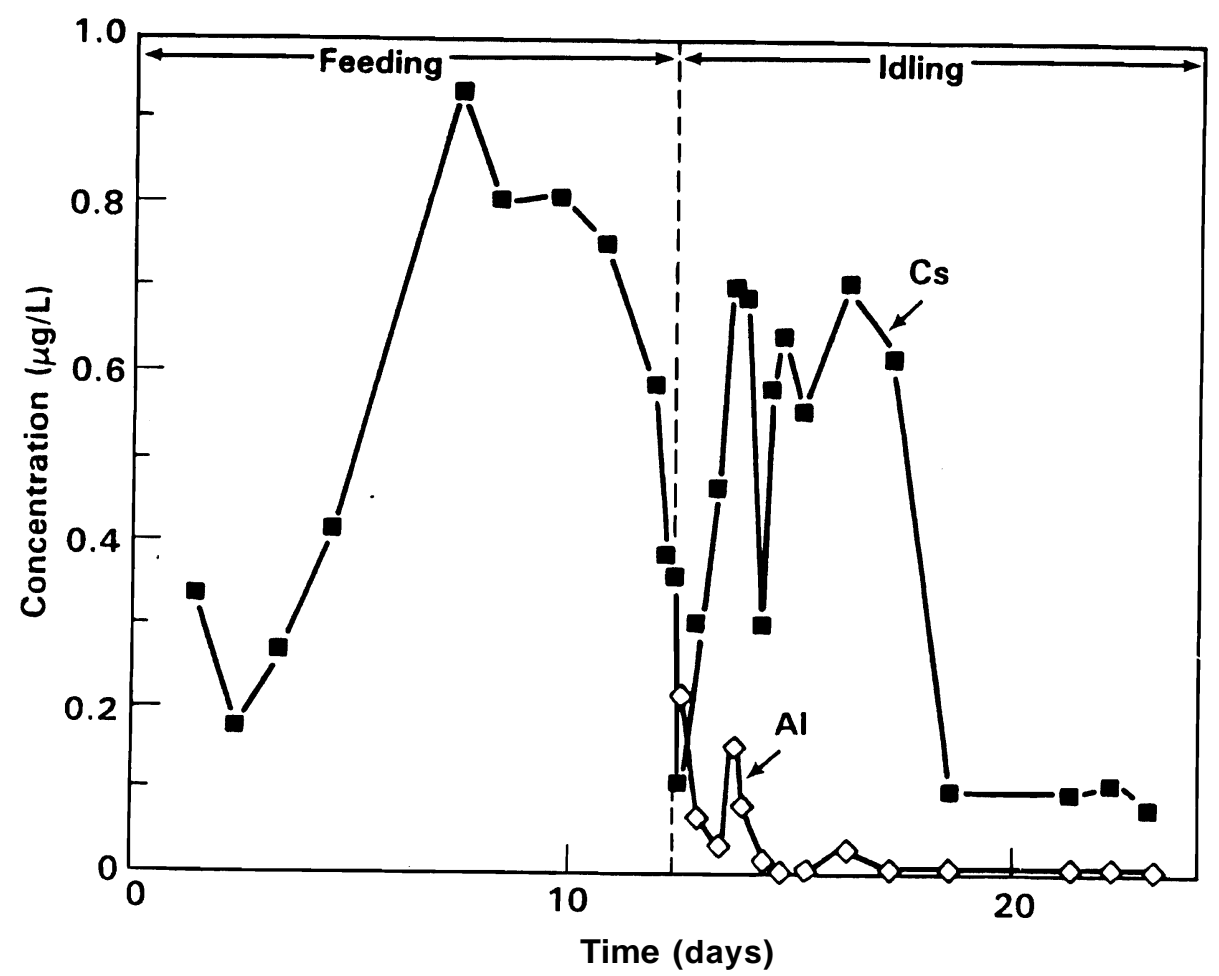

FIGURE 7. Melter Off-Gas Emission Characteristics (Goles and Andersen 1986) 
The apparent temperature-dependent emission characteristics associated with nonvolatiles arise from the entrainment produced from the temperaturedependent melting of plenum surface deposits and the resultant turbulence produced by plenum debris falling back into the hot glass pool. Since the magnitude of entrainment induced by burn-off is only $-1 \frac{\circ}{\circ}$ of that occurring during feed processing, Figure 7 presents only nonvolatile idling emission properties (e.g., Al) so as not to suppress the other data presented.

The burn-off characteristics of all the semivolatile alkali elements are essentially identical except for their magnitudes; this is consistent with a totally temperature-dependent phenomenon. Moreover, the peak emission rate values during burn-off do not generally exceed their corresponding melter processing loss rates. However, plenum burn-off emission rates of trace semivolatile feed components such as cesium far exceed those associated with major nonvolatile feed components, which suggests that the melter plenum can and does act as a significant sink for semivolatile effluent. As a result, melter DFs derived from off-gas emission studies can overestimate LFCM glassification efficiencies for the semivolatiles. The structured burn-off emission characteristics described above only apply to nonboosted LFCM operation; use of plenum heaters precludes the build-up of plenum surface deposits.

Long-term idling emission characteristics are flat, unstructured, and significant only for semivolatiles (i .e., boron, cesium, sodium, ruthenium, and various halogenated and sulphur compounds). As Figure 7 clearly shows, these long-term semivolatile loss rates, of which cesium presents a worst case, are generally found to be significantly lower than those occurring during melter feed processing. However, the magnitudes of these emission rates are functionally dependent upon glass concentrations. Figure 8 characterizes melter cesium emission rates during. and after the production of a -5 wt cesium-loaded glass. Under these high glass-loading conditions, long-term idling emissions of cesium are seen to be nominally equivalent to the losses associated with maximum feed processing conditions. Moreover, since peak and long-term emission rates are not found to be dramatically different after processing the high cesium-loaded feed, it appears that the glass pool may 


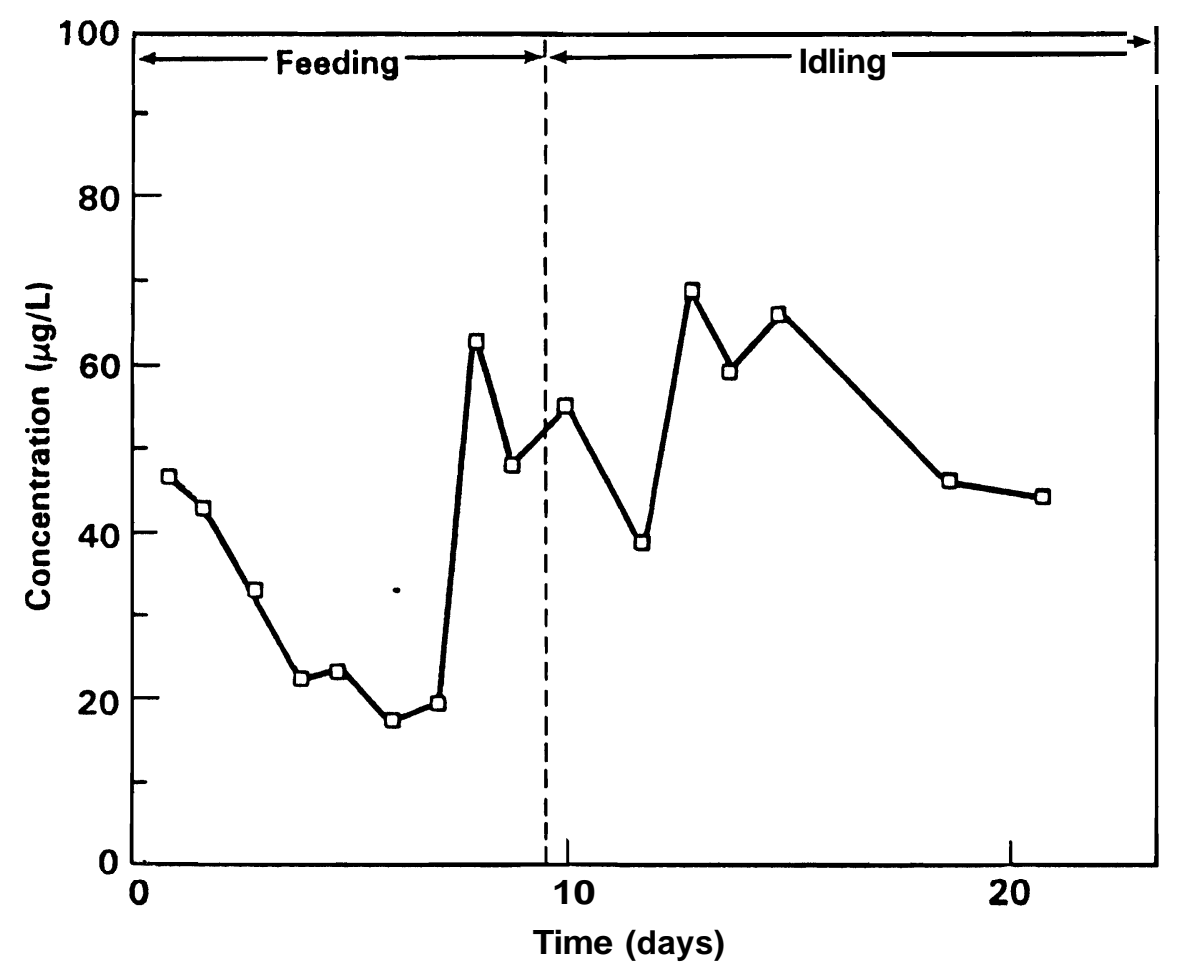

FIGURE 8. Cesium Off-Gas Emissions During and After Processing a High Cesium-Bearing Feed (PSCM-20)

significantly influence the melter cesium source term during all phases of idling and possibly during feed processing as well. This has never been the case for low (<0.5 wt\%) cesium-bearing feeds.

Since the semivolatile idling emission characteristics of a melter are temperature-dependent, idling emission rates can be controlled by regulating the melter plenum temperature.. This was demonstrated at PNL using a fine water mist plenum spray, which cooled but did not disturb the surface of the melter glass pool (Goles and Sevigny 1983a). This temperature-dependence study was initiated immediately after a 120-h liquid-fed melter test. With a 42-1iters/hour water spraying rate and the melter under automatic control to maintain the bulk tank temperatures approximately constant, the melter glass surface was cooled to the point that it formed a continuous, nonconvective layer above the bulk melter glass pool (with plenum at $280^{\circ} \mathrm{C}$ ). When the spray rate was decreased to 27 liters/hour, the surface temperatures increased and the viscosity decreased significantly. In addition, convective mixing opened 
vents in the glass surface that migrated at random across the glass pool. However, plenum temperatures were not high enough to melt feed deposits formed upon the melter walls and lid during the preceding melter (PSCM-5) experiment. Finally, the cooling spray was terminated and the melter was allowed to idle, which slowly brought the melter plenum up to $850^{\circ} \mathrm{C}$. Samples were collected from the plenum during all phases of this study.

The results obtained from these plenum samples are graphically summarized in Figure 9, which characterizes the emission rates of the semivolatile elements under various idling conditions (temperature) employed during this test. These data indicate that emission rates of all semivolatile elements decreased as a function of time after the completion of PSCM-5 at a 42-liters/ hour water spraying rate. Reducing the cooling spray rate to 27 1iters/hour

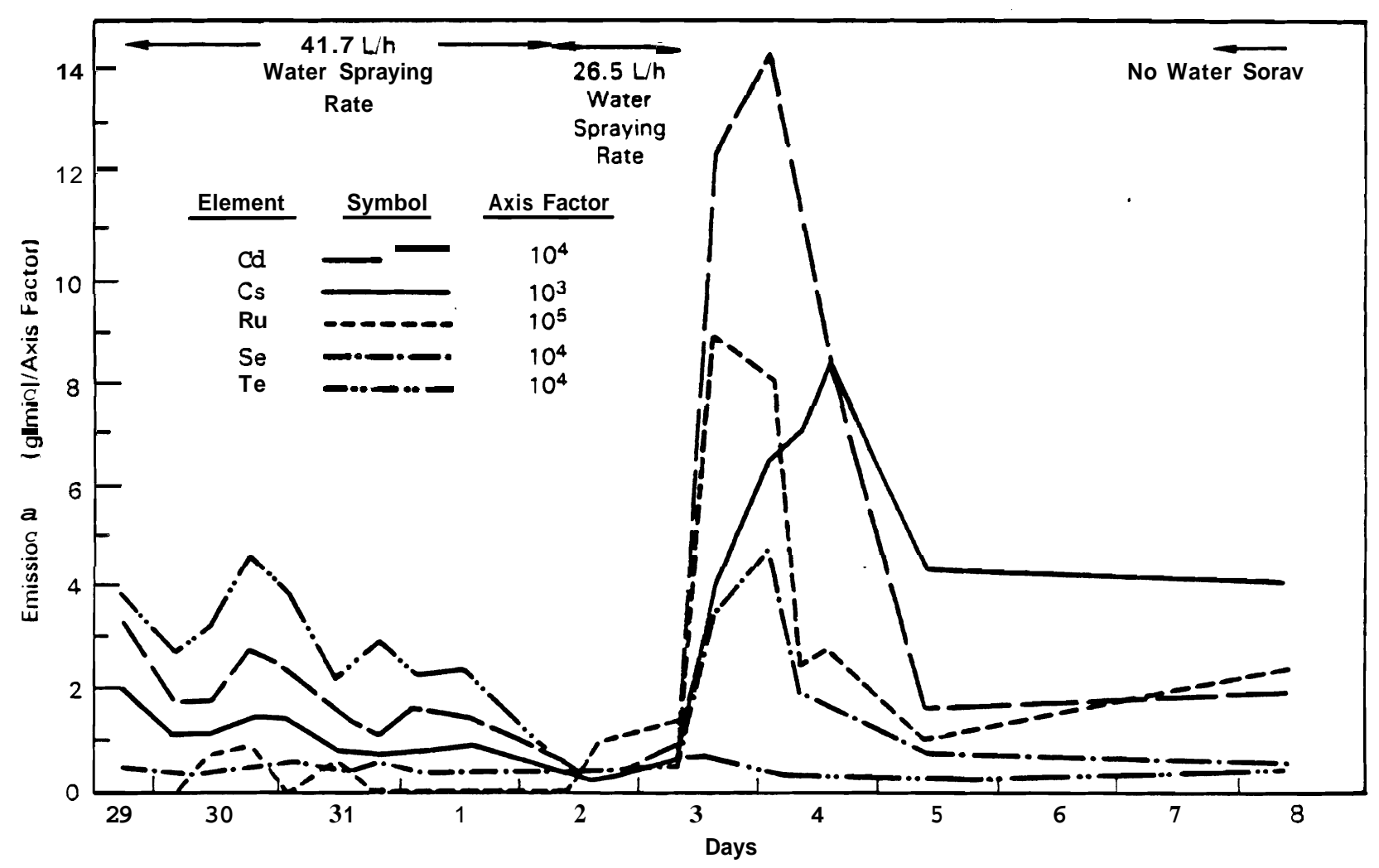

FIGURE 9. Emission Rates of Semivolatile Elements During Melter Idling 
increased both plenum temperature and semivolatile emission rates; however, an equilibrated plenum temperature was not achieved during the brief 24 -h period of reduced spraying.

Termination of the water-cooling spray increased the plenum temperature steadily to the point where plenum surface deposits formed during previous feed processing began to melt and "burn" away. The dramatic peaking of emission rates of the semivolatile elements occurred during this period. The emission characteristics under these plenum warm-up conditions are very similar to those described earlier.

\subsection{LFCM OFF-GAS PROCESSING REOUIREMENTS}

Because of the operating characteristics of LFCMs, a contaminated gas phase waste stream is generated by the process that requires treatment before it can be released to the environment. A MOG treatment system provides this function by pulling off these hot, contaminated, steam-1aden emissions and decontaminating them. As discussed previously, LFCM process exhaust consists primarily of steam, volatilized effluent, and suspended aerosols. Since most waste components that require long-term environmental isolation are lost to the off-gas system as condensed phase matter'(aerosol s), LFCM process off-gas (POG) treatment systems are composed primarily of aerosol emission abatement devices and ancillary support equipment.

Like other high-temperature combustion processes, vitrification produces two distinct and independent classes of aerosol effluent: entrained and semivolatile condensed matter (see previous section for details). Because many radioactive semivol atiles such as ${ }^{137} \mathrm{Cs}$ form condensation aerosols which are primarily of submicron size, high-efficiency aerosol removal devices are required components of LFCM processing systems. However, these devices are not, in general, compatible with high off-gas aerosol and steam loadings or with high melter exhaust temperatures; consequently, aqueous quench scrubbers are universally used to precondition the process exhaust by cooling the exhaust stream, condensing the steam, and removing large-diameter $(>1 \mu \mathrm{m})$ entrained debris. Because entrained matter can also present an off-gas line 
blockage problem, off-gas quenchers are usually close coupled to the melter source to minimize or at least localize this problem.

In general, a third stage of off-gas treatment would be required if one or more radioactive waste components formed a gaseous effluent that was thermodynamically stable and was little affected by the aqueous quench scrubbing stage. However, radionuclides such as these $\left({ }^{3} \mathrm{H},{ }^{14} \mathrm{C}\right.$, and $\left.{ }^{129} \mathrm{I}\right)$ are usually not significant components (curie basis) of HШW. Consequently, the off-gas technologies used to support the U.S. vitrification plants do not provide special removal capabilities for these isotopes.

The process off-gas system used in support of the DWPF, the WWP, and the HMP are illustrated in Figures 10 through 12, respectively. These offgas technologies are functionally equivalent, although the actual equipment comprising these systems varies somewhat. Both HWP and WMP employ a submerged-bed scrubber (SBS) and high-efficiency mist eliminator (HEME) as the

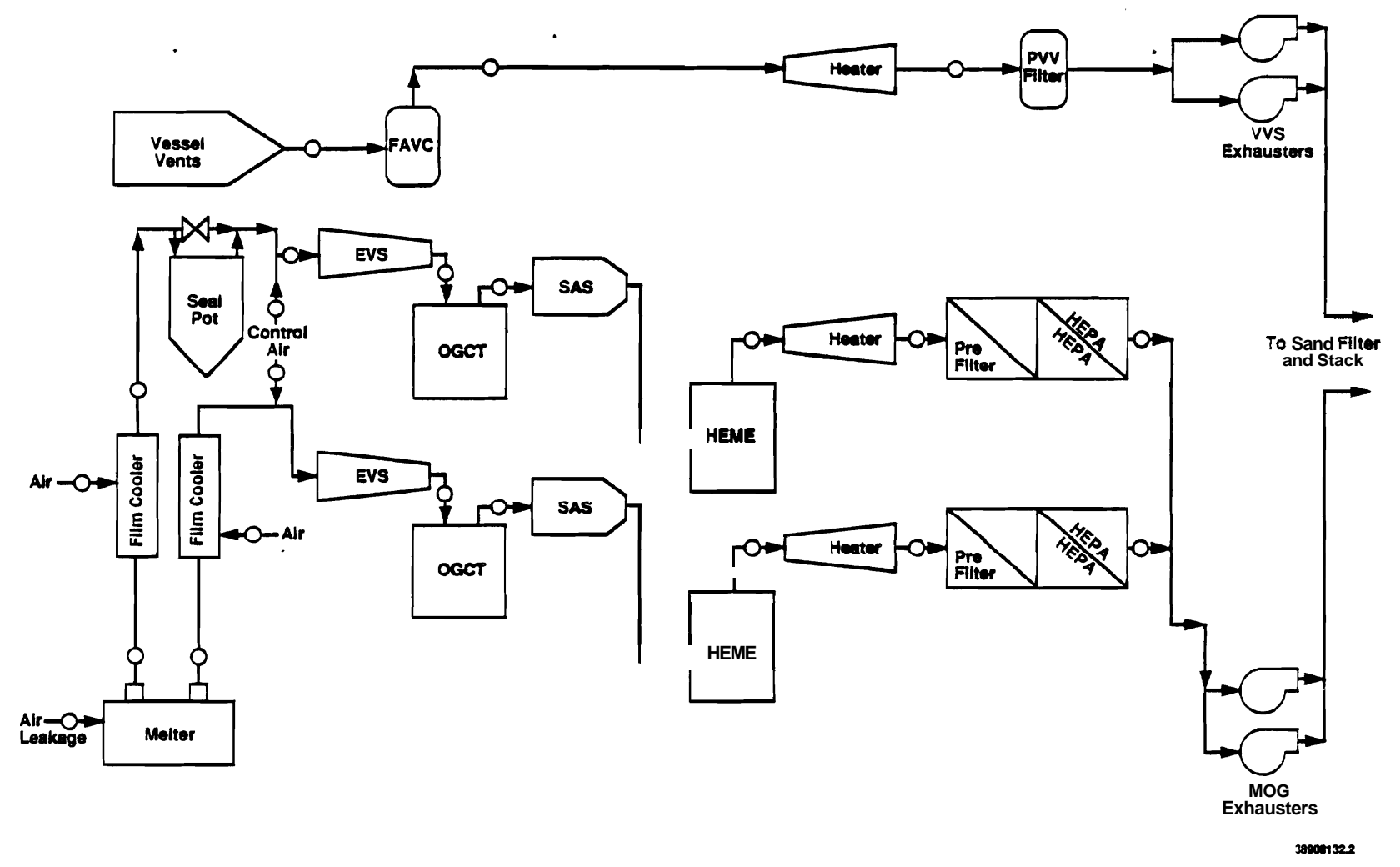

FIGURE 10. DWFF Process Off-Gas System 


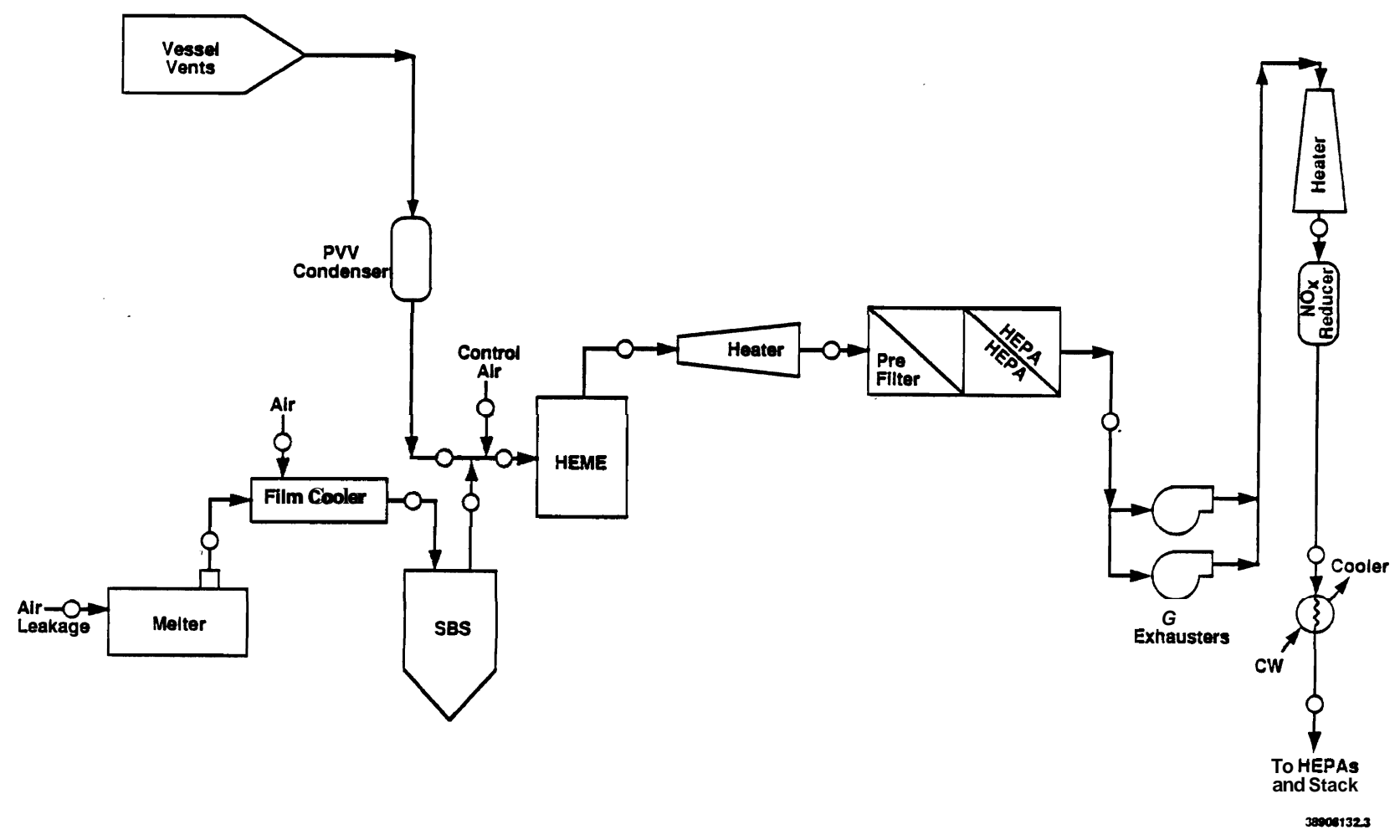

FIGURE 11. WWP Process Off-Gas System

primary quench scrubber and high-efficiency aerosol removal device, respectively. The DWPF, on the other hand, utilizes an ejector venturi as its quench scrubber and employs a tandem steam-atomized scrubber (SAS) in addition to a HEME to remove submicron aerosols. All MOG systems use a dual in-line high-efficiency particulate air (HEPA) filter assembly as a final removal stage for off-gas submicrons before the melter exhaust stream leaves the processing cell. A final stage of high-efficiency filtration occurs before process stream gases are released to the stack. This is accomplished with a sand filter at the DWPF, a HEPA and a sand filter at the HWWP, and by a tandem HEPA filter assembly at the WDP.

Other differences between these POG systems that have no impact on routine system performance are the following:

- The DWPF MOG system design has a fully redundant back-up system.

- The HWVP uses the vessel vent system as a MOG back-up system. 


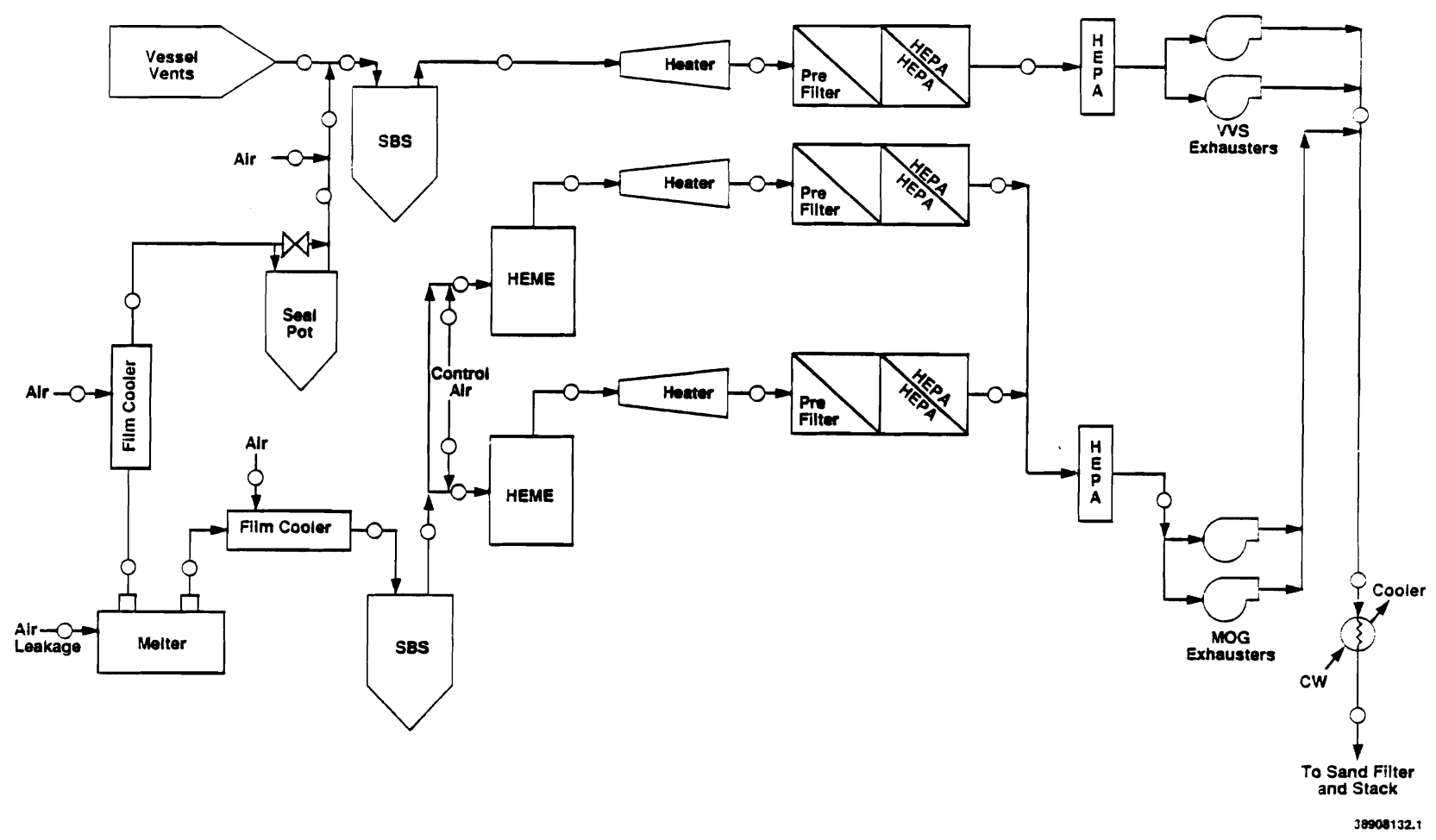

FlGURE 12. HWVP Process Off-Gas System

- The WVDP has no MOG back-up system.

- The WVDP uses the MOG system as part of its vessel vent system.

In order to compare the effluent emission abatement capabilities of the three off-gas technologies, the performance expectations of individual off-gas system devices need to be established. Off-gas equipment operating characteristics and performance data are discussed in the following sections.

\subsubsection{Primary Scrubbers}

As discussed above, two different types of quench scrubbers are used in off-gas system designs supporting U.S. vitrification plants. Of the three off-gas technologies being considered here, only the DWPF design calls for an ejector-venturi scrubber (also called a jet or eductor scrubber). This scrub ber has been used for many types of industrial emissions since the early 1960s. As shown in Figure 13, the device utilizes a high-pressure spray nozzle that atomizes liquid to particle-collecting droplets. These units have a 


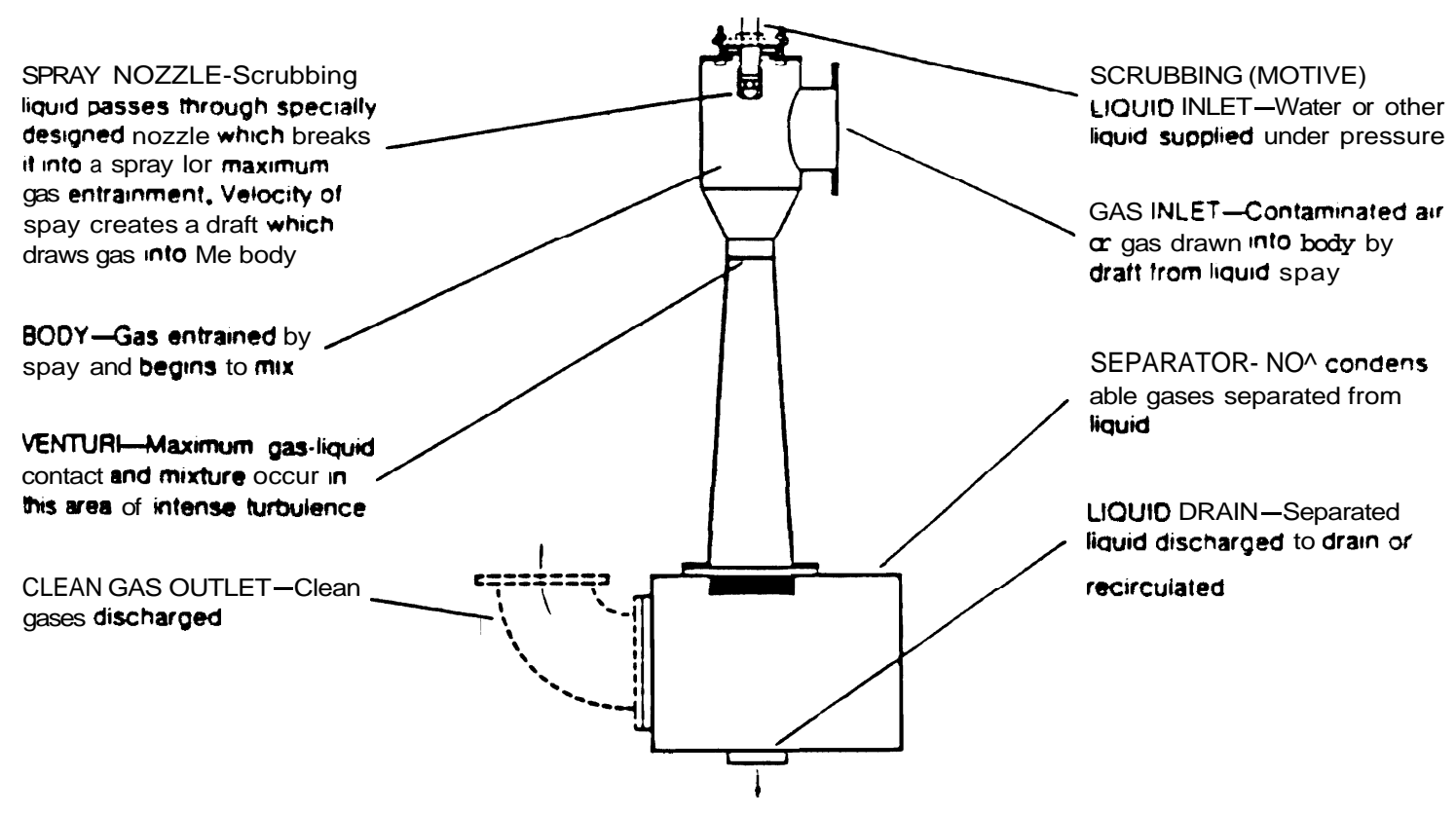

FIGURE 13. Principle of Operation of Ejector-Venturi Scrubber

large water consumption compared to other scrubbers--50 to 100 gal per $1000 \mathrm{ft}^{3}$ of gas handled. The liquid spray stream provides motive force for the gas; rather than a pressure drop, a draft of several inches of water can be developed. High relative velocity between 1iquid droplets and gas aids in separating the two streams (Calvert et a1. 1972). Harris (1966) describes the three major activities of the ejector-venturi: 1) impaction of the fume particle by a larger, faster-moving water droplet, 2) retention or capture of the particles by the water drop, and 3) removal or separation of the water drop containing the particle from the air or gas stream. Separation is generally accompl ished with a simple gas reversal chamber.

The EVS was selected over other scrubber types for LFCM service at the DWPF because it is effective for aerosols down to $1 \mu \mathrm{m}$ in size, is compact and thus requires little radioactive process cell space, is simple to operate, has few vul nerable internal components, and because a given unit can accommodate wide variations in inlet gas volume, temperature, and composition. The only major equipment required to support the ejector scrubber is a recirculation pump and a tank for storage of liquid. 
The quench scrubber utilized in WWP and HWP off-gas designs is a SBS. Originally conceived as a self-cleaning aerosol scrubber for reactor containment emergency ventilation systems (Hilliard, McCormack, and Postma 1981), the SBS is a packed cylindrical bed submerged in a scrub solution vessel; gas to be cleansed enters at the bottom of the bed through a central downcomer pipe. Off-gas system vacuum and gas buoyancy drives liquid recirculation as the gas is pulled upward via the POG system blowers. The recirculating water removes heat from the off gas and provides for gas scrubbing and cleaning of the bed. These processes are shown in the schematic of Figure 14. As liquid and gas make concurrent contact in the bed, the liquid is heated. The outer portion of the vessel is fitted with cooling coils to remove this heat. Because of

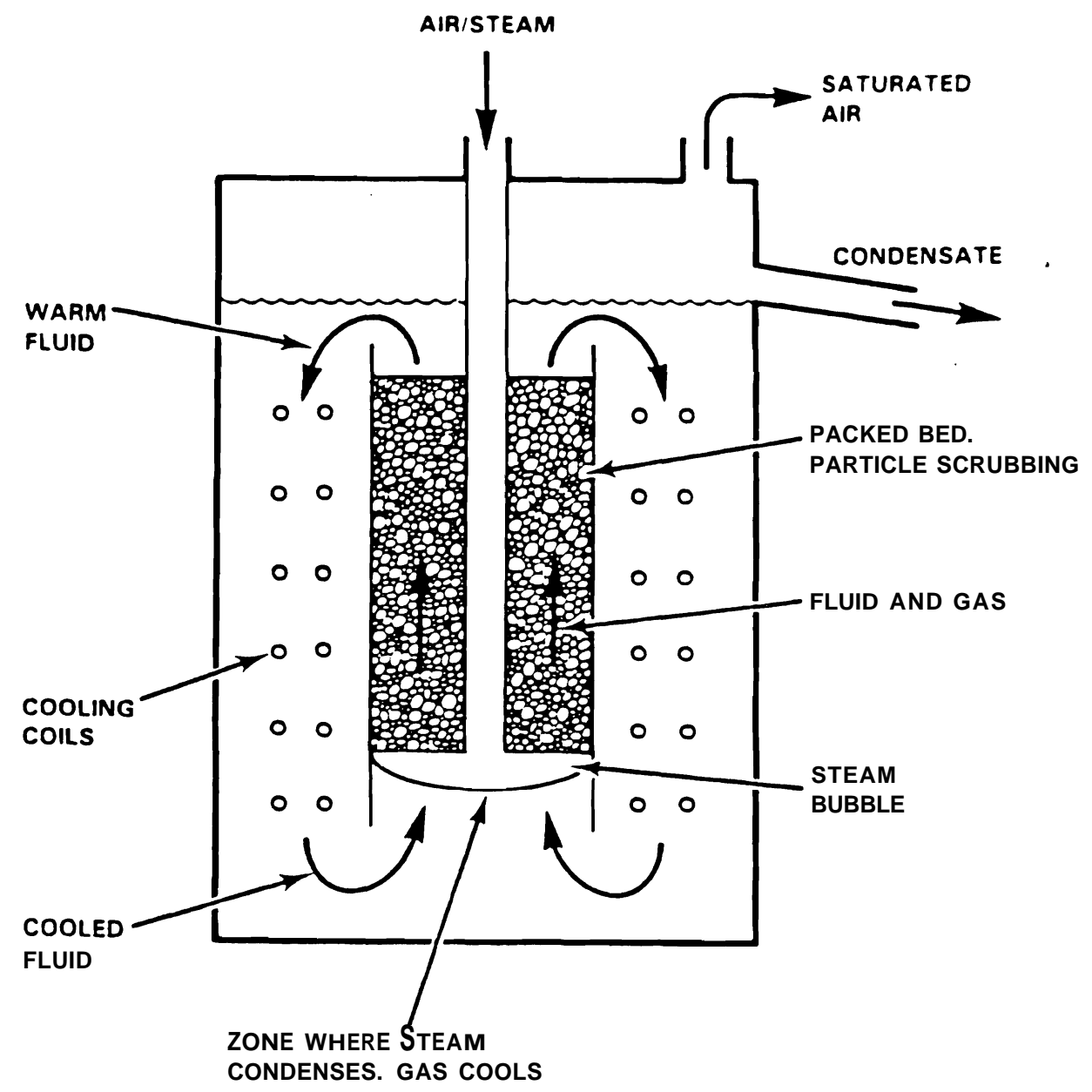

FIGURE 14. Principle of Operation of Submerged-Bed Scrubber 
this internal recirculation, no external pump is needed, a significant advantage because scrub liquid is abrasive and usually corrosive. Since the quenching and scrubbing functions of the SBS do not require active process support, this device is inherently more reliable and predictable than the EVS, which does. However, the price paid for passivity is a high pressure drop through the bed, which is set by the submergence of the inlet gas pipe-nominally 38 inches.

The following two subsections discuss and compare the emission abatement performance characteristics of these two devices, the EVS and the SBS, as they relate to aerosol and gaseous effluent collection.

\section{Aerosol Col Tection Performance of Primary Scrubbers}

By design, quench scrubbers are low-efficiency devices capable of removing only large-diameter $(>1 \mu \mathrm{m})$ airborne particulate matter. A typical particulate removal performance curve of an EVS obtained from manufacturer data sheets is reproduced as Figure 15. Since scrubbing efficiency is also dependent on scrubbing fluid pressure, grain loading, and the composition and density of the inlet gas, the ordinate scale of this performance curve will vary depending on conditions; however, the shape of the curve will not. As a result, this type of scrubber is exceedingly useful for eliminating 1 argediameter effluent entrained in the process off-gas stream. Moreover, since this type of scrubber can accommodate wide variations in inlet gas volume, temperature, and composition, it is also well suited for absorbing the impacts of processing upsets, which act to significantly increase off-gas aerosol and steam loadings. Because of the nature of the EVS performance curve and the size distribution characteristics of entrained matter, process upsets should not, in general, significantly affect downstream processing conditions.

The SBS quench scrubber is not a commercial product and as such its performance cannot be easily generalized. However, the original design of this device, which has been adapted to LFCM applications, has been tested and documented. Using a polydispersed $\mathrm{Na}_{2} \mathrm{O}$ aerosol having a mass median diameter of $3 \mu \mathrm{m}$, Owen and Postma (1981) recorded SBS scrubbing efficiencies in excess of 99\%. Ruecker and Scott (1987) later used submicron aerosols to evaluate the influence of SBS operating parameters on removal efficiency. One of the more 


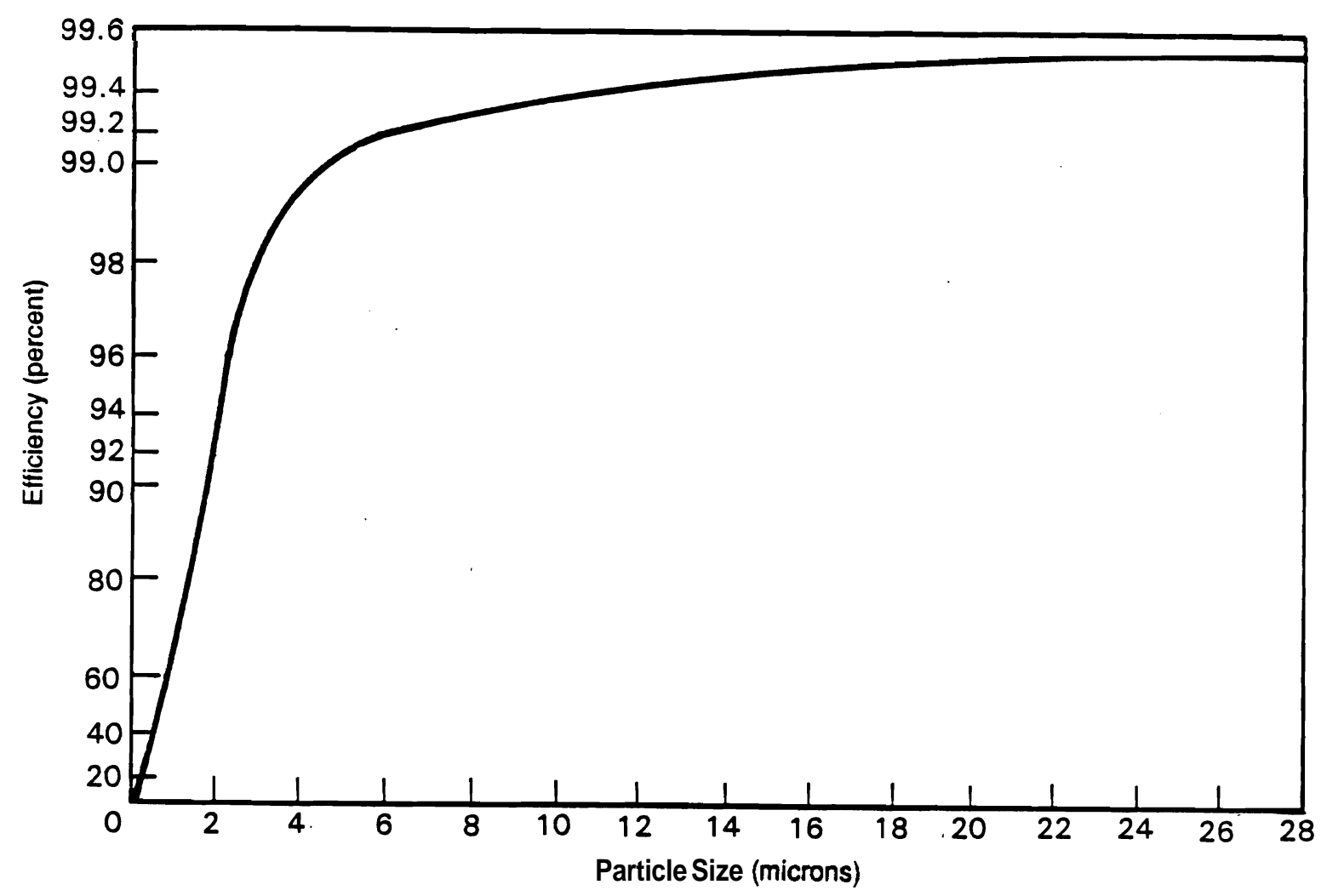

FIGURE 15. Typical Particulate Removal Efficiencies for Type 7014 Ejector Venturi Scrubbers (Ametek Catalog, Technical Supplement 7S)

important relationships identified in this study was the dependence of aerosol DF (influent mass/effluent mass) upon superficial face velocity, which is reproduced in Figure 16. Taken together, these data suggest that the overall performance characteristics of the SBS quench scrubber are quite similar to those of the EVS, although SBS performance may be slightly higher for submicron matter.

Experimental MOG performance data have indeed shown the two quench scrubbers to behave comparably under typical LFCM operating conditions, as evidenced by comparing the size distribution characteristics of quench scrubber influent aerosols (Table 3 ) with characteristic effluent aerosols (Table 9) penetrating these devices. Given the demonstrated equivalence of LFCM quench scrubbers and their operational characteristics, quench scrubber elemental DFs (influent concentration/effluent concentration) should, in 


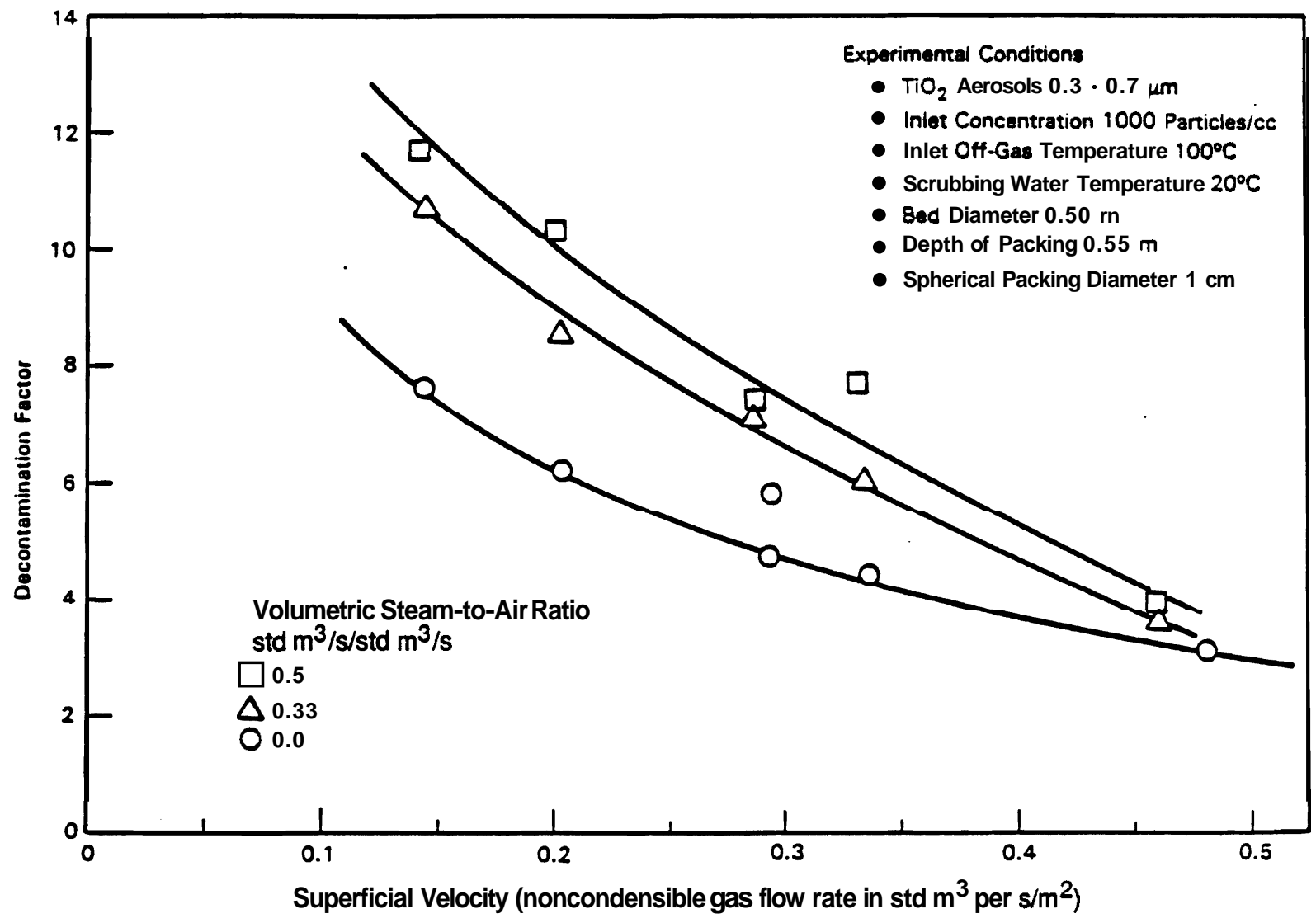

FIGURE 16. Influence of Steam on SBS Performance $\left(\mathrm{TiO}_{2}\right)$ (Ruecker and Scott 1987)

\section{TABLE 9. Aerosol Characteristics Exiting Quench Scrubbers}

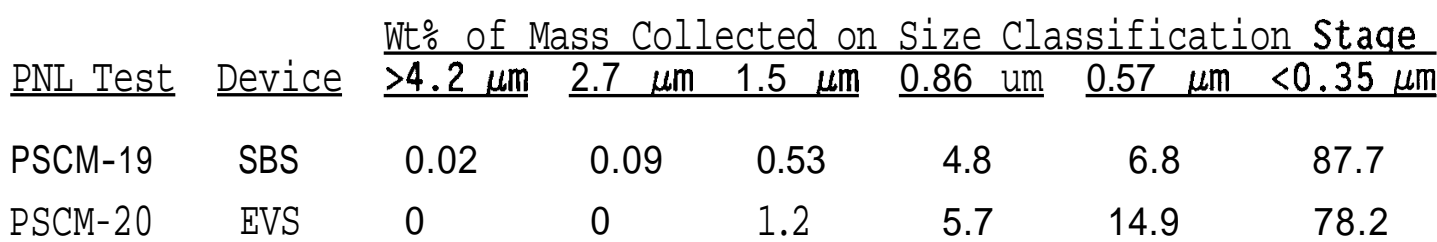

general, be direct measures of the mass medium diameter of the aerosols responsible for individual feed component losses. Specifically, low DFs would be expected for feed components, 1ike cesium, which are volatilized and quickly converted, by reaction and/or condensation, to predominantly submicron aerosols. On the other hand, much higher DFs should occur for nonvolatiles like strontium, whose off-gas system losses are due primarily to gross feed 
entrainment. Such is indeed the case for both the EVS and SBS, as the results in Table 10 clearly show. The variability of the overall (mass) DFs listed in this table reflects the relative importance of entrainment and volatilization loss mechanisms. When most of the aerosol mass leaving a melter is associated with submicron matter as in the PSCM-9 and PSCM-20 tests (see Table 2), low overall scrubber DFs result. Conversely, high mass scrubber DFs result when melter tests are characterized by high entrainment losses as in PSCM-8 and PSCM-15 (Table 2). Since feed entrainment does not significantly affect the melter cesium effluent source, the quench scrubber cesium DFs tend to be less variable from test to test than are the results obtained from nonvolatile or overall mass effluent data. However, the concentration and mass median diameter of the semivolatile effluent aerosols, like the nonvolatiles, do vary from test to test, which results in some quench scrubber performance variability. These facts are demonstrated by both the EVS and SBS DF results in Table 10. Since the average off-gas performances of these two scrubbers are essentially indistinguishable in this set of unrelated LFCM tests, they will be considered equivalent and the effects of various melter and off-gas operating conditions (upsets, flow rate and concentration) upon scrubber performance wi11 be discussed below in a strictly generic sense.

TABLE 10. Volatile and Nonvolatile Quench Scrubber DFs

\begin{tabular}{|c|c|c|c|c|}
\hline \multirow[b]{2}{*}{ PNL Test } & \multirow{2}{*}{$\begin{array}{c}\text { Scrubber } \\
\text { Type }\end{array}$} & \multicolumn{3}{|c|}{ Quench Scrubber DF } \\
\hline & & Cs & $S r$ & Mass \\
\hline PSCM-8 & EVS & 11 & 300 & 54 \\
\hline PSCM-9 & EVS & 7.1 & $>900$ & 6 \\
\hline PSCM-15 & SBS & 5.8 & 9800 & 32 \\
\hline PSCM-16 & SBS & 9.5 & 1300 & 28 \\
\hline PSCM-17 & EVS & 5.8 & 360 & 36 \\
\hline PSCM- 19 & SBS & 6.0 & 1300 & 29 \\
\hline PSCM-20 & EVS & 1.7 & 44 & 2 \\
\hline PSCM-21 & SBS & 1.5 & 1600 & 18 \\
\hline PSCM-22 & EVS & 1.4 & 260 & 5 \\
\hline PSCM-23 & SBS & 3.3 & 370 & 7 \\
\hline
\end{tabular}


Process Upsets. Processing instability can result from various operations or conditions, such as overfeeding, glass reboil or foaming, feed rate variations and/or interruptions, and cold cap bridging. The effects of these upsets, as discussed previously, are increased melter entrainment losses, which quench scrubbers should be fully capable of handling. Table 11 presents melter and quench scrubber (SBS) performance data taken before $(5 / 30-6 / 3)$, during $(6 / 3-6 / 7)$, and after $(6 / 7-6 / 9)$ a processing upset initiated by a feed compositional change. The diametrically opposed response of the scrubber to the changes in melter mass DF clearly demonstrates the scrubber's ability to absorb the resultant increase in off-gas aerosol loading. Although the melter upset was significant and prolonged, the cesium DFs of the melter and scrubber did not vary significantly, nor did the variability of these DFs correlate with the process upset event in accordance with expectations. Consequently, the conditions downstream of the quench scrubber did not vary significantly in spite of a 10X increase in melter aerosol emission rate.

Off-Gas Flow Rate and Steam Loading. The PNL melter off-gas processing system has supported LFCM testing with and without the use of a film cooler

TABLE 11. Melter and Quench Scrubber Responses to a Processing Upset ${ }^{(a)}$

\begin{tabular}{|c|c|c|c|c|c|c|}
\hline \multirow[b]{3}{*}{$\frac{\text { Day }}{5 / 30}$} & \multicolumn{6}{|c|}{ DF } \\
\hline & \multicolumn{2}{|c|}{ Melter } & \multicolumn{2}{|c|}{ Ouench Scrubber } & \multicolumn{2}{|c|}{ Overall } \\
\hline & $\frac{\text { Mass }}{150}$ & $\frac{\text { Cesium }}{30}$ & $\frac{\text { Mass }}{28}$ & $\frac{\text { Cesium }}{1.8}$ & $\frac{\text { Mass }}{4200}$ & $\frac{\text { Cesium }}{54}$ \\
\hline $6 / 1$ & 270 & 29 & 12 & 1 & 3200 & 29 \\
\hline $6 / 2$ & 250 & 55 & 14 & 1 & 3500 & 55 \\
\hline $6 / 3$ & 160 & 34 & 20 & 1.9 & 3200 & 64 \\
\hline $6 / 4$ & 24 & 34 & 100 & 1.3 & 2400 & 44 \\
\hline $6 / 6$ & 86 & 25 & 28 & 1.4 & 2400 & 35 \\
\hline $6 / 7$ & 145 & 15 & 13 & 1.9 & 1900 & 29 \\
\hline $6 / 8$ & 140 & 19 & 19 & 2.2 & 2600 & 42 \\
\hline $6 / 9$ & 200 & 52 & 19 & 1.2 & 3800 & 62 \\
\hline
\end{tabular}

(a) PSCM-21 WVDP sponsored LFCM tests. 
(Scott, Goles, and Peters 1985). When not employed, the unquenched off-gas system flow is composed of melter-generated gases (mostly steam) and air inleakage. Under these conditions, steam loadings of $75 \%$ are common. With an air-driven film cooler, the unquenched off-gas stream is so diluted that a $75 \%$ air composition normally results. Consequently, the use of an air-driven film cooler acts to increase unquenched off-gas system flow rates while significantly reducing steam volume collapse during the quenching process. Both effects might be expected to reduce contacting and resultant scrubbing efficiency. However, no statistically significant losses in quench scrubber performance have been observed to be associated with film cooler operation.

Table 12 compares cesium and overall mass quench scrubber DFs obtained under both off-gas operating conditions. These data are quite comparable except for the low average cesium DF measured during PSCM-21. This low value is apparently not related to a scrubber contacting problem, as the sodium values also listed in this table are not similarly affected; rather, a much smaller spectrum of Cs-bearing aerosols must have been produced during that test.

Scrubber Solution Composition. When the LFCM off-gas system is operated with an air-driven film cooler, melter effluents concentrate in quench scrubber solutions because of reduced steam collection efficiencies and solution entrainment losses. Indeed, under noncondensing conditions, the concentrations of feed components will continually increase until the scrubber solution is recycled or diluted. For soluble effluents like cesium, the implication

TABLE 12. Quench Scrubber Response to an Air-Driven Off-Gas Line Film Cooler

\begin{tabular}{|c|c|c|c|c|c|}
\hline \multirow[b]{3}{*}{ PNL Test } & \multirow{3}{*}{$\begin{array}{c}\text { Film } \\
\text { Cooler } \\
\end{array}$} & \multirow{3}{*}{$\begin{array}{l}\text { Melte r } \\
\text { Mass } \\
\end{array}$} & \multicolumn{3}{|c|}{ DF } \\
\hline & & & & nch Scr & \\
\hline & & & Mass & $\underline{\text { Cesium }}$ & $\underline{\text { Sodium }}$ \\
\hline PSCM-15 & $\mathrm{N}$ & 240 & 32 & 6.0 & 19 \\
\hline PSCM-16 & $\mathrm{N}$ & 160 & 30 & 9.5 & 33 \\
\hline PSCM-19 & Y & 350 & 29 & '6.0 & 23 \\
\hline PSCM-21 & $Y$ & 190 & 19 & 1.5 & 18 \\
\hline
\end{tabular}


of this concentration effect is to decrease net scrubber efficiency by increasing re-entrainment loss rates. The magnitude of this effect, of course, depends upon off-gas and scrub liquor effluent concentrations and offgas re-entrainment rates.

Because of the turbulent operating conditions associated with the SBS, the scrubbing performance of this device could very well be limited by the re-entrainment rates of previously removed effluent matter. This technical issue was specifically addressed during the HWVP-15/PSCM-23 melter test (Goles and Nakaoka 1990). Examination of the time-dependent, SBS effluent off-gas concentration data collected during that test reveals (see Figure 17) that when the melter source is turned down, as occurs for nonvolatiles during idling, the SBS effluent off-gas concentrations of these feed components also dramatically decrease. Moreover, the SBS exhaust concentrations of the semivolatiles, whose melter emissions persist but decrease during idling, also decrease in a corresponding way with the melter source term. This is found to be true for both soluble and insoluble matter. Consequently the effluent matter being exhausted from the SBS is predominantly airborne material that simply and directly penetrates the device, and the contributions from re-entrainment are found to be insignificant under projected HWVP operating conditions.

The above result has also been previously demonstrated for an EVS quench scrubber during a melter test (PSCM-20) involving a liquid slurry containing high (5 wt\%) cesium content (Goles and Anderson 1986). Table 13 summarizes the performance of an EVS quench scrubber measured over a continuous 20-day interval, during which time there was a five-fold increase in semivolatile scrubbing liquor concentration. Clearly, the variability in observed quench scrubber performance for cesium does not correlate with scrub liquor concentration trends and no relationship between cesium (semivolatile) scrubbing efficiency and re-entrainment of scrubbing liquor was observed.

From the above results, it is abundantly clear that quench scrubbers in general are insignificant contributors to post-scrubber effl uent concentrations when compared to penetrating melter emissions under the conditions of the melter tests studied. Since the SBS data were taken under projected HWVP 


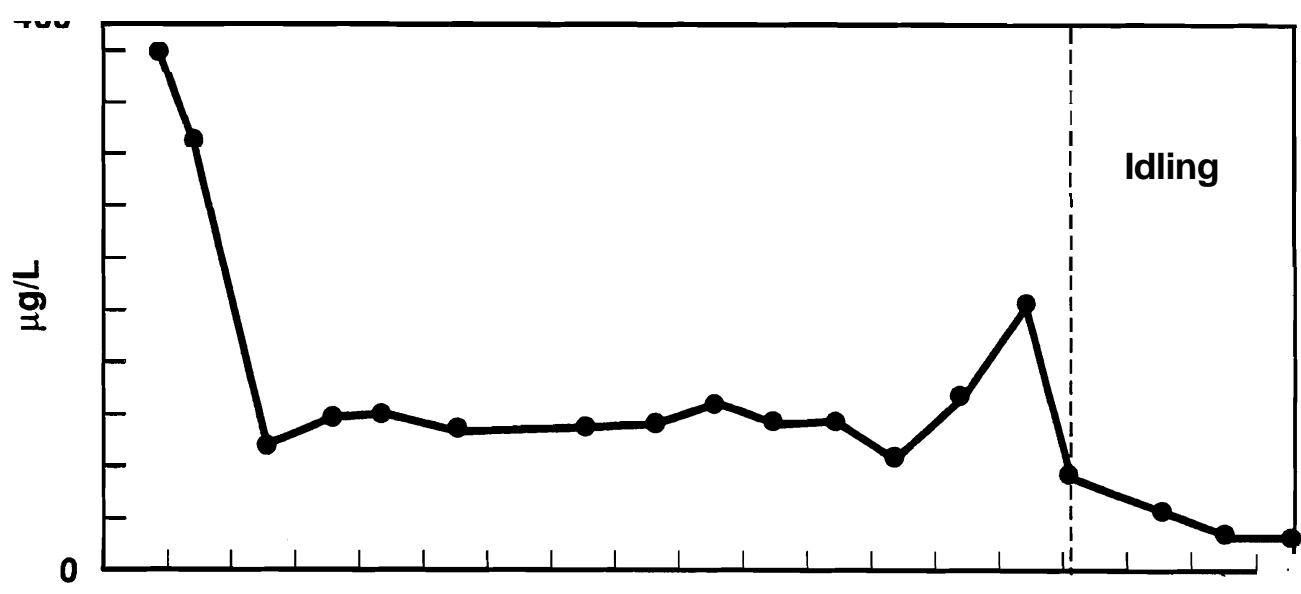

6/6/88 Time (days)

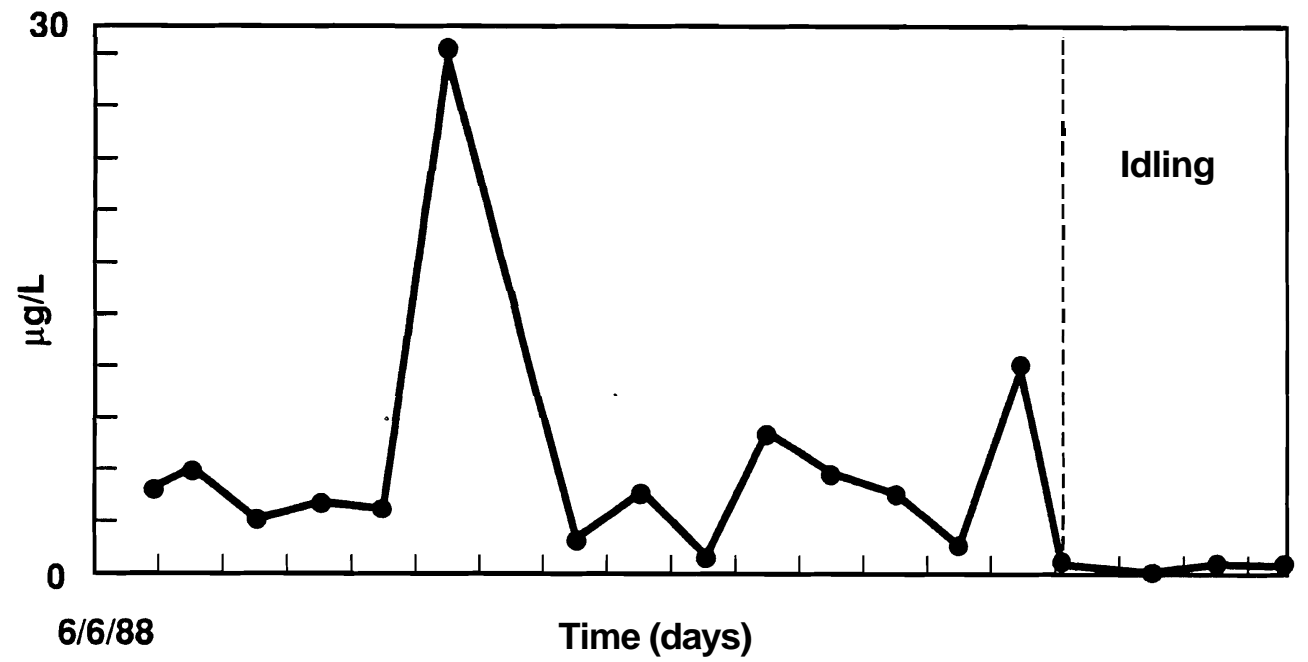

39203088.1

FIGURE 17. Strontium Concentrations in Melter (top) and SBS (bottom) Off-Gas Steams During Processing and Idling

process conditions and the EVS results represent worst-case conditions due to the 10X cesium content of the feed, the conclusions drawn should be valid for all reasonable off-gas operating conditions.

\section{$\underline{\text { Radioactive Gas Collection Performance of Primary Scrubbers }}$}

The radioactive isotopes of particular importance with regard to LFCM gaseous emission are carbon-14, tritium, ruthenium-106, technetium-99, and iodine-129; the major chemical forms responsible for the gaseous emission of 
TABLE 13. Quench Scrubber Performance as a Function of Scrub Liquor Concentration

\begin{tabular}{lcc} 
& \multicolumn{2}{c}{$\begin{array}{c}\text { Quench Scrubber } \\
\text { Cesium Characteristics }\end{array}$} \\
\cline { 2 - 2 } Date & $\begin{array}{c}\text { Liquor } \\
(\mathrm{mg} / \mathrm{L})\end{array}$ & DE \\
$4 / 2$ & 139 & 1.8 \\
$4 / 4$ & 244 & 2.0 \\
$4 / 6$ & 234 & 2.0 \\
$4 / 8$ & 193 & 1.2 \\
$4 / 10$ & 224 & 1.8 \\
$4 / 13$ & 469 & 1.2 \\
$4 / 15$ & 674 & 2.2 \\
$4 / 17$ & 880 & 3.0
\end{tabular}

these elements are $\infty, \quad H T O$ (tritiated water), $\mathrm{RuO}_{4}, \mathrm{Tc}_{2} \mathrm{O}_{7}$, and $\mathbf{I}_{3}$, respectively. Due to the physical and chemical properties of $\mathrm{CO}_{x}$ effluent, ${ }^{14} \mathrm{C}$ emission abatement is not provided by any of the LFCM off-gas systems being considered in the study. Quench scrubber control of LFCM tritium emissions, if required, is limited to condensation and/or exchange processes which, if used in combination, would produce a secondary waste stream at least as large as that of the HШW being processed. Fortunately, tritium is only a very minor component (curie basis) of aged $\mathrm{H} \amalg W$, and specific off-gas operating conditions to limit vitrification plant emissions of this isotope are not anticipated at any of the U.S. sites. In spite of this, significant quantities of HTO will be removed by normal condensation and disengagement processes associated with quench scrubber operations. Assuming a $35^{\circ} \mathrm{C}$ scrub liquor operating temperature, a moisture-saturated, 500 SCFM off-gas flow rate, and $100 \mathrm{kilograms/hour} \mathrm{processing} \mathrm{rate,} \mathrm{a} \mathrm{quench-scrubber/HEME} \mathrm{HTO} \mathrm{DF} \mathrm{of}-5$ would be predicted. This projection was confirmed during scaled HWVP-15/PSCM-23 testing (Goles and Nakaoka 1990), where $80 \%$ of the process steam was recovered by an SBS.

Gaseous emission of ruthenium and technetium can only occur under strongly oxidizing process conditions. Because reduced feeds will be used at 
all U.S. vitrification facilities, no significant volatilization of ruthenium and technetium isotopes will occur under normal processing conditions. On the other hand, if the melter glass becomes strongly oxidized during prolonged periods of idling, volatilization of ruthenium and technetium could occur during the initial stages of process start-up. Under worst-case conditions, volatile ruthenium loss rates of $-90 \%$ could occur until the reduced feed had sufficiently modified the oxidizing conditions within the melter. Fortunately, quench scrubber DFs for gaseous ruthenium are quite high due to a combination of condensation and chemical decomposition processes. No evidence for ruthenium gaseous penetration of quench scrubbers (either SBS or EVS) has been found at PNL. Using the analytical detection limit associated with gas scrubber samples generated during LFCM processing of oxidizing feed, a lower quench scrubber DF for gaseous ruthenium has been estimated to be 100 .

There are very little data concerning LFCM emission characteristics of technetium because no stable isotope of this element exists. No volatility of technetium is projected under normal HWVP processing conditions as the feed.is sufficiently reduced. Whether $\mathrm{Tc}_{2} \mathrm{O}_{7}$ could be generated in a reduced feed by an oxidized glass is unknown; however, vol ati le technetium effluent(s) produced from highly oxidized feeds have been found to be quite penetrating at the PAMELA facility in Mol, Belgium. In any case, technetium volatility need not be a processing concern if the oxidizing conditions of both the glass and the feed are monitored and controlled. Because many of the physical and chemical properties of technetium are quite similar to those of ruthenium, IFCM off-gas behavior of technetium will also be assumed to be similar, for the purposes of this report; consequently, ruthenium off-gas data will be used to model technetium in the evaluations to follow.

Unlike ruthenium and technetium, gaseous evolution of the halogens is to be expected from LFCMs irrespective of feed composition; however', the processing of oxidizing feeds will strongly promote losses of these elements. In particular, complete melter volatilization of iodine in the feed as $\mathrm{I}_{2}$ is expected under these conditions. Although data on quench scrubber DFs for I, are limited, the study that was conducted on an oxidizing WVDP feed (PSCM-9) suggests a negligible scrubbing efficiency ( $D F-1)$ for this gaseous effluent. 
Fortunately, very $1 \mathrm{ittle}{ }^{129} \mathrm{I}$ is present in H世W (curie basis) because waste handling practices effectively remove this element from HШW streams.

\subsubsection{Hiah-Efficiency Aerosol Scrubbers}

As discussed in previous sections, a large portion of melter-emitted aerosols are submicron, and those that are not are effectively removed by the off-gas quench scrubber. Consequently, post-quencher off-gas conditions require high-efficiency removal of rather high concentrations of very small $(\leq 1 \mu \mathrm{m})$ aerosols. It is generally not practical to collect these emissions solely with HEPA filters because frequent changeout of these filters would be required. As a result, other high-efficiency, low-maintenance devices have been identified and employed in vitrification off-gas system designs to effectively reduce submicron aerosol concentrations to levels that will extend the service life of the subsequent HEPA filter to at least one year. Two such devices have been employed in U.S. vitrification designs: a Hydro-Sonic@ scrubber (HSS) and a high-efficiency mist eliminator (HEME). While both of these units are employed in the DWF design, only the HEV is used by the WWP and the HWP off-gas systems.

The HSS is an air-or steam-aspirated wet scrubber that collects aerosols using a supersonic nozzle to efficiently atomize water by injecting water into the wake of an expanding free jet (see Figure 18). A brochure ${ }^{(a)}$ describes the phenomenon: dirty gas is driven through a free-jet nozzle fitted with a water-injection ring where water is, injected on to the driven gas stream. Turbulent mixing occurs as the free jet expands, causing capture of particulates in the very fine submicron sizes.

The HVE (Figure 19) is composed of a deep-bed regenerable filter configured so it can be irrigated and drained and is most effective for collection of soluble mists or fumes. HEMEs were originally developed by Brink (1964) for removal of acid or caustic fumes, and are available today from several domestic vendors with either fiberglass or polypropylene packing. Like HEPA filters, these devices can efficiently remove airborne submicron

(a) From Hydro-Sonic@, Lone Star Steel Company, Dallas, Texas. 


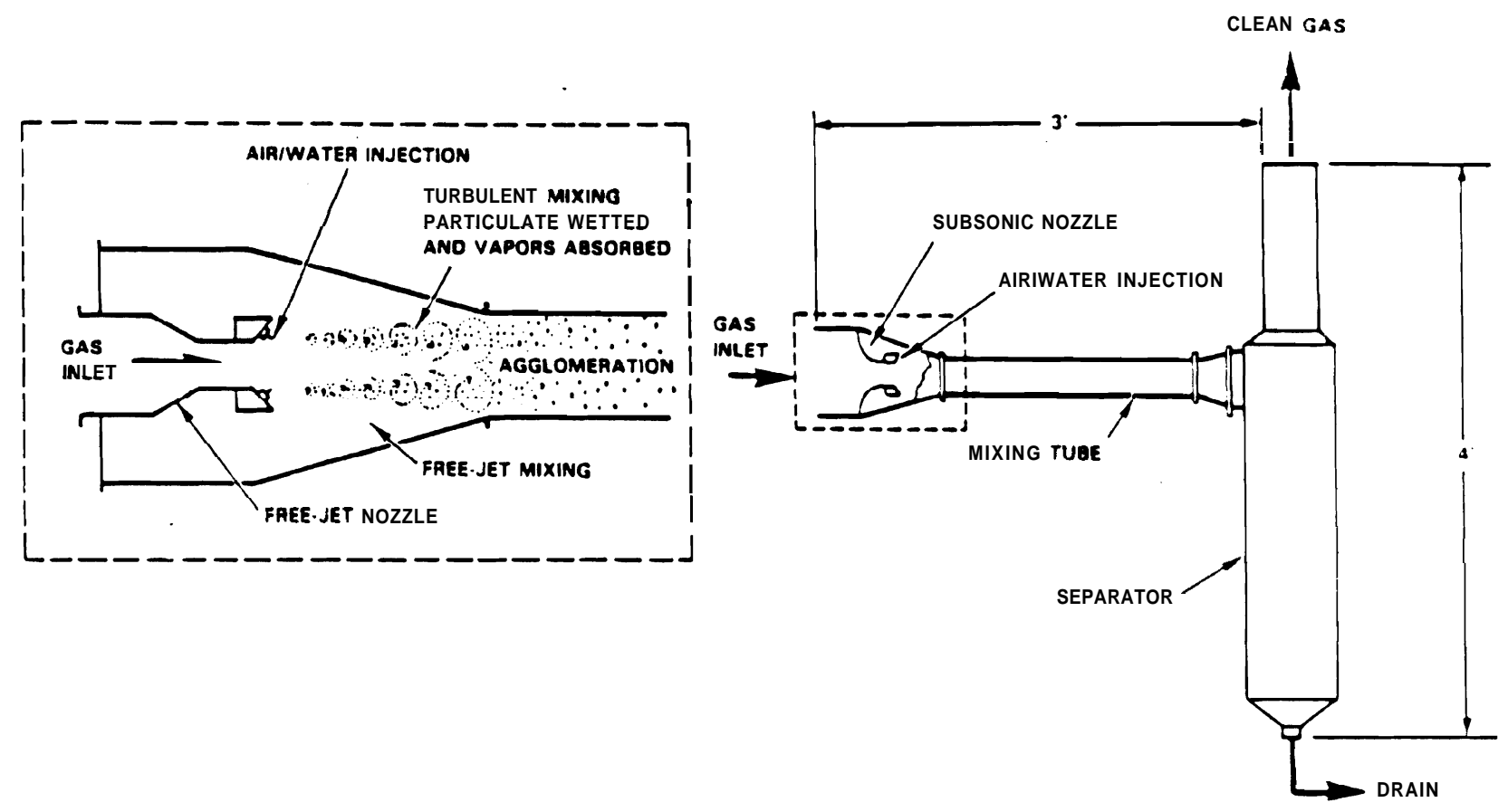

FIGURE 18. Principle of Operation of Hydro-Sonice Scrubber

matter but, unlike HEPA filters, they can be operated wet to allow simultaneous removal of both liquid and solid-state aerosols. Since these filters can be operated wet, a continuous water spray has often been employed to wash down and cleanse filter elements of accumulated debris, thus extending the service life of these devices. In LFCM service, much of the airborne material penetrating the off-gas quench scrubber is water soluble (alkali salts); consequently, continuous irrigation or batch washing operations should be quite successful in purging the filter of accumulated effluent, thereby extending effective service life of these remotely replaceable filters.

The final treatment step in all U.S. melter off-gas system designs involves HEPA filtration or its equivalent. This type of filter is universally used in nuclear air or gas cleaning systems as the final barrier between a containment area where radioactive particles could be generated and the point of envi ronmental release--the stack. Of all the aerosol abatement devices considered up to this point, HEPA filters provide the greatest contribution to the overall system performance. Their inclusion in LFCM off-gas 


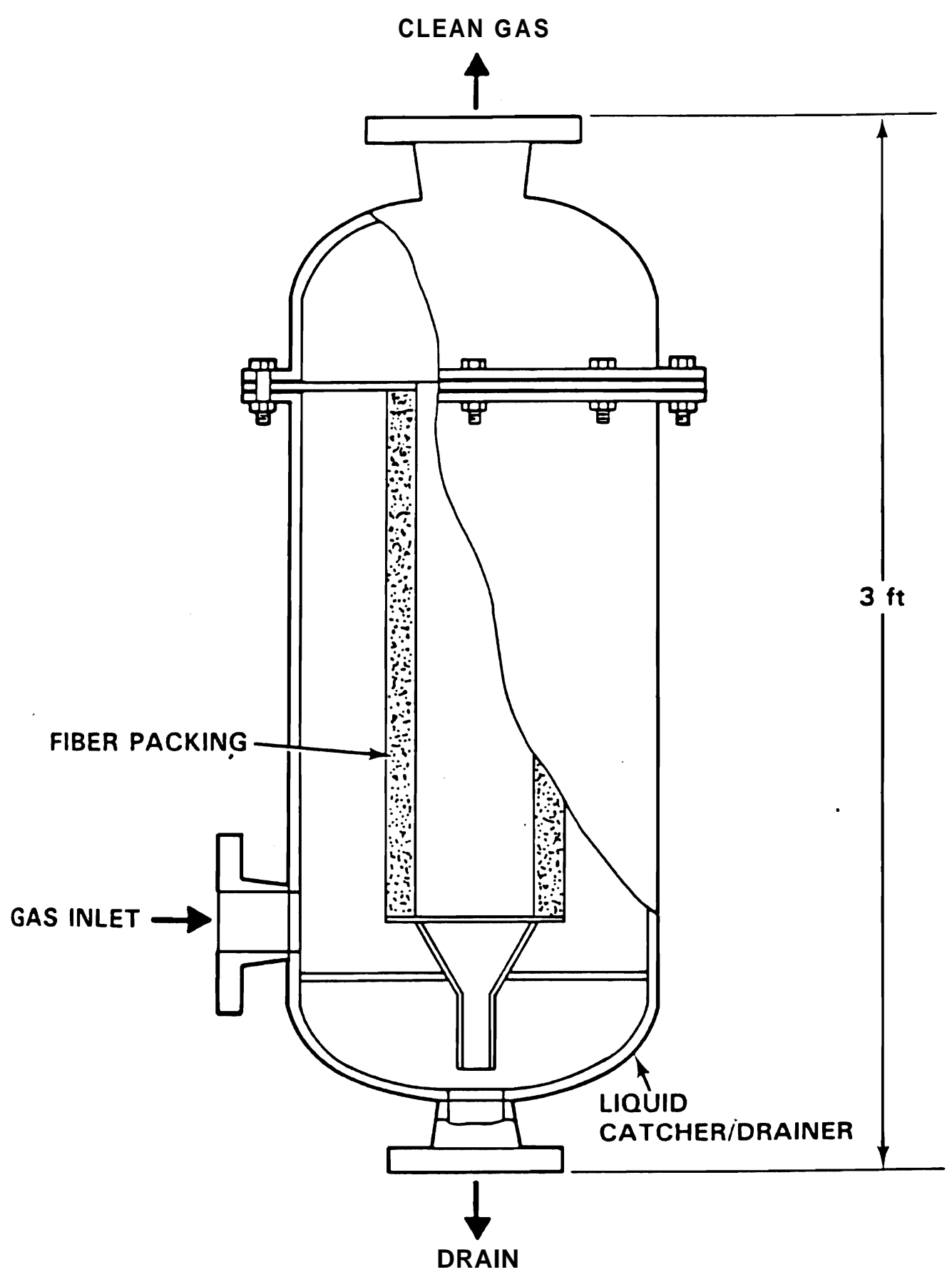

FIGURE 19. Schematic of High-Efficiency Mist Eliminator Used in PNL's PSOM Off-Gas System 
systems ensures thorough decontamination of process-generated radioactive aerosols before stack discharge. All three off-gas system technologies being evaluated utilize a tandem HEPA filter assembly to filter the melter exhaust before it is discharged from the processing cell, and a second filter bank--a tandem HEPA assembly at the WDP, a sand filter at the DWPF, and a singlestage HEPA followed by a sand filter at the HWVP--is used as a final filtration stage before process gases are released to the environment.

The following subsections discuss experimentally derived operational performance characteristics of these high-efficiency aerosol removal devices.

\section{Hydro-Sonic@Aerosol Scrubbina_Efficiency}

The LFCM off-gas testing of HSSs has been almost exclusively conducted at SRS $^{(a)}$ although PNL has some limited experience. The SRS off-gas design provides for two cascaded hydrosonic devices directly downstream of the LFCM ejector-venturi quench scrubber. Consequently, most of the LFCM scrubbing performance data associated with this device involve the tandem, cascaded system that is designed to meet a DWPF-required DF of 50 for cesium aerosols.

To properly appreciate the operating characteristics of the tandem HSS configuration, it is essential to understand the performance characteristics of a single-stage unit. The most definitive performance studies of steamdriven HSSs were conducted by the Southern Research Institute on open-hearth furnaces that generated challenge aerosols having a mass median diameter of $1 \mu \mathrm{m}$ (McCain and Smith 1974). The results of these tests established both the overall mass and fractional efficiency of the HSS as a function of aerosol diameter. Figure 20 summarizes typical HSS inlet and outlet size distributions of effluent aerosols obtained during stable furnace operations and Figure 21 summarizes HSS fractional efficiencies calculated from these data together with cascade impactor measurement results. Fractional efficiency data were also collected during less optimal conditions when inlet aerosol concentrations varied over a considerable range. These cascade impactor data are

(a) W. P. Colvin. 1983. Off-Gas System Data Summarv for the Ninth Run of the Larqe Slurrv-Fed Melter. DPST-83-809, Savannah River Laboratory, Aiken, South Carolina. 


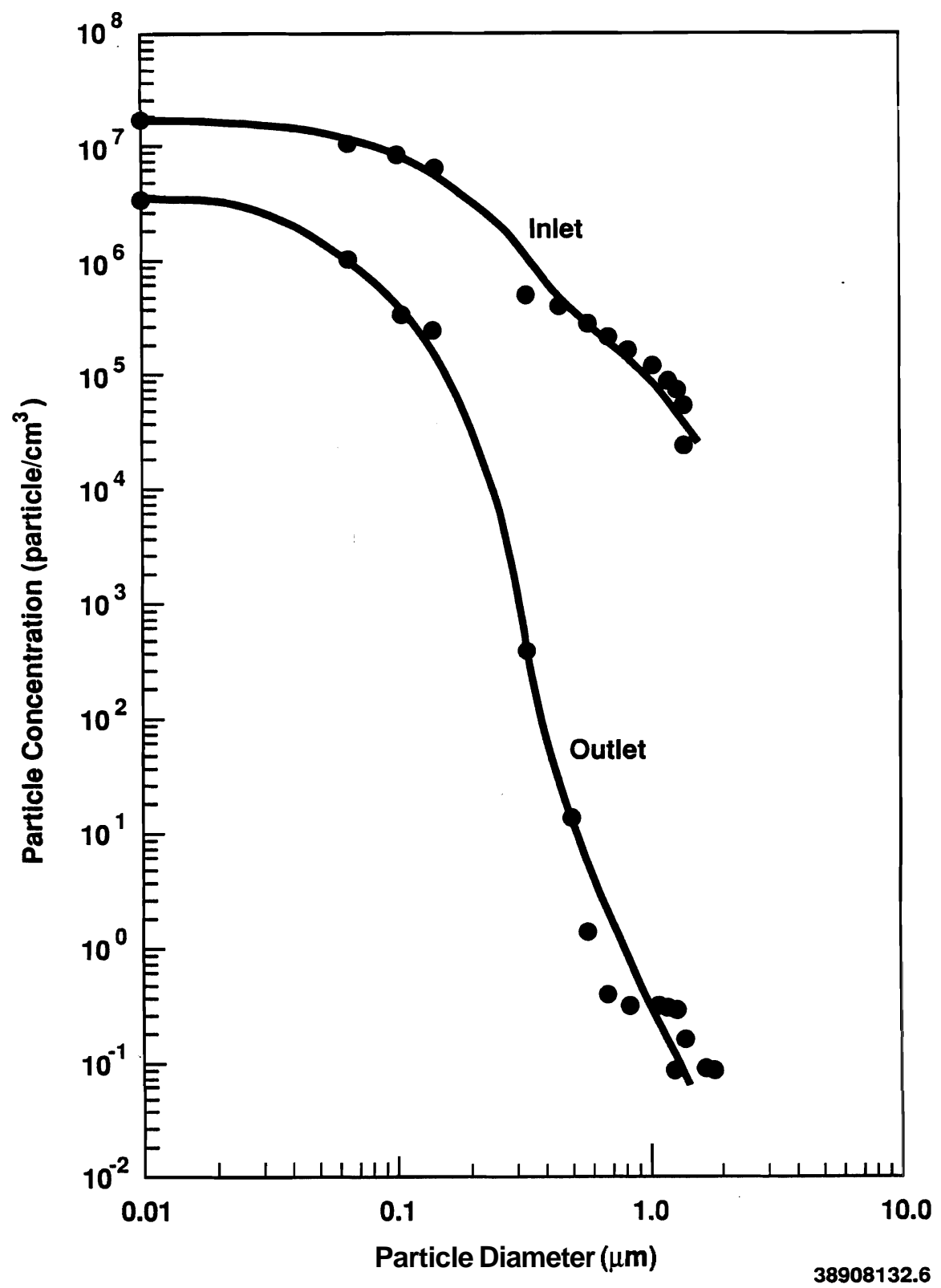

FIGURE 20. Inlet and Outlet Particle Size Distributions Measured Using Optical and Diffusional Techniques

presented in Figure 22 under various HSS operating conditions. Overall DFs obtained during this study were in excess of 600 .

Wright (1983) conducted simi 1ar HSS performance tests using air rather than steam as the motive scrubbing fluid. The DF results obtained were slightly lower on the average than the furnace test data. The difference in 


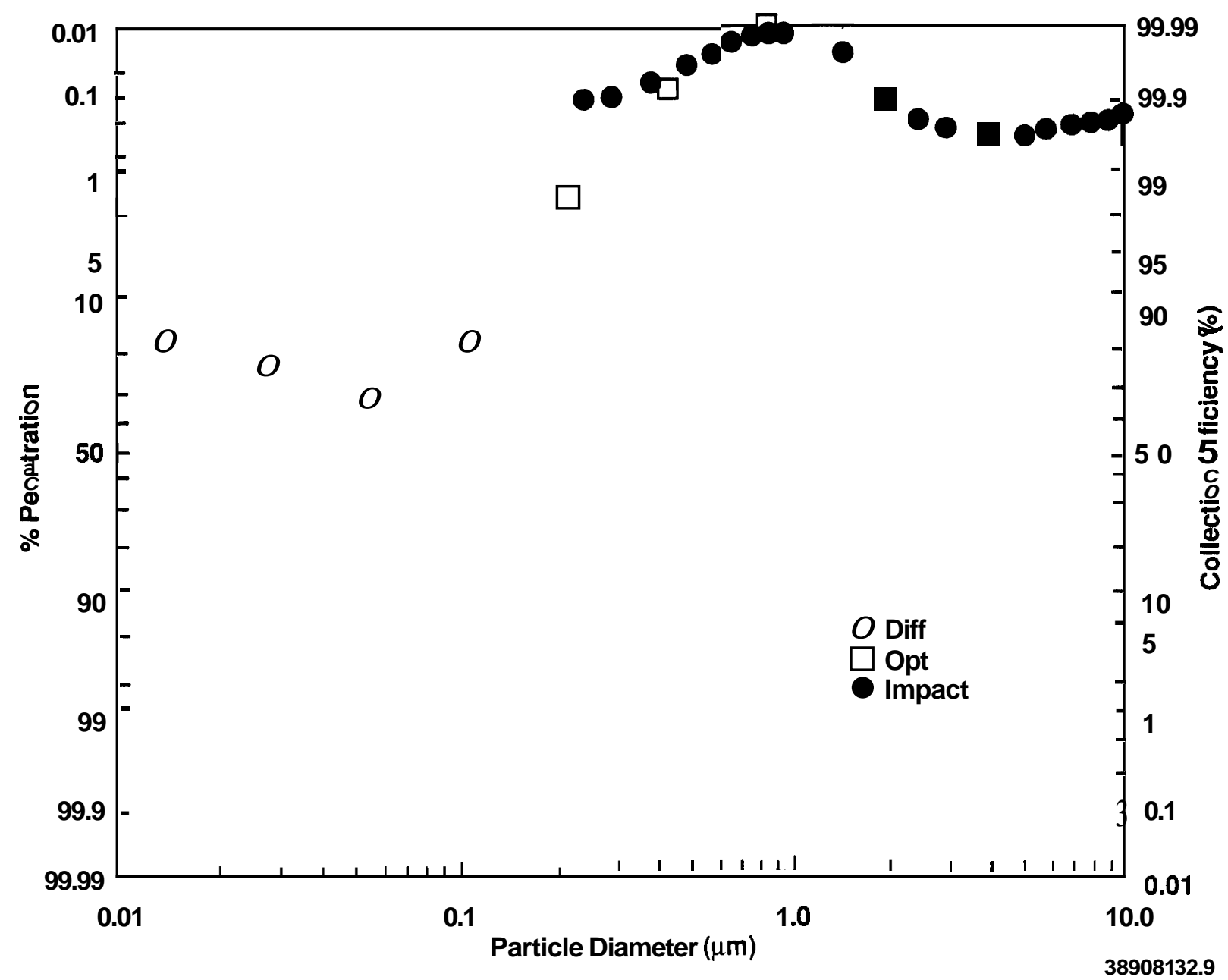

FIGURE 21. Fraction Efficiency of the Lone Star Steel Steam-Hydro Scrubber

Some empirical HSS performance data have also been collected during scaled melter tests. Table 14 presents some representative scrubber data collected at SRS. In each case HSS influent conditions were established by quench scrubber modifications to a processing melter source. The single-stage data indicate that the mass median diameter of alkali elements containing aerosols is quite small, $<0.3 \mu \mathrm{M}$; furthermore, by comparing the single- and dual-stage alkali elements data it appears that efficiency of the first scrubbing stage does not impair or degrade the performance of the second cascaded unit. This observation is consistent with the HSS operating principles which 


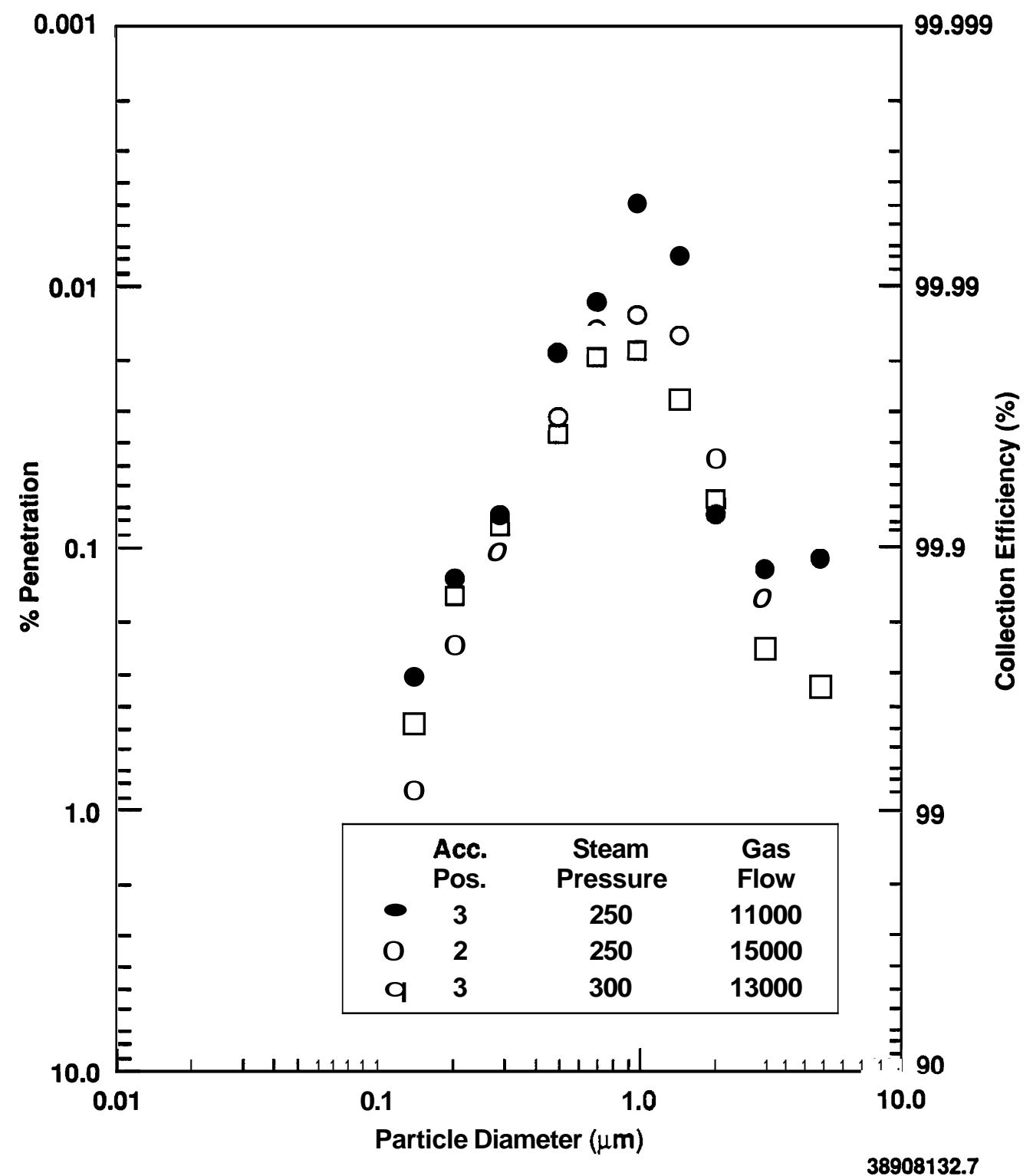

FGURE 22. Fractional Efficiency Calculated Using Impactor Data Only

act to modify the influent aerosol size distribution to effect removal. Since the growth and removal of influent aerosols is a statistical phenomenon, the HSS cannot act to screen out aerosols on the basis of their initial aerodynamic diameters; consequently, for sub-micron aerosols, the overall DF of a dual, cascaded device should be the square of that of an individual unit, which is approximately what is observed. 
TABLE 14. Hydrosonic DFs

\begin{tabular}{ccc} 
El ement & \multicolumn{2}{c}{ DF } \\
\cline { 2 - 3 } $\mathrm{A} 1$ & Cascaded & Sinqle \\
$\mathrm{n}$ & -- & -- \\
$\mathrm{Ba}$ & -- & - \\
$\mathrm{Ca}$ & -- & -- \\
$\mathrm{Cr}$ & -- & -- \\
$\mathrm{Cs}$ & -- & -- \\
$\mathrm{Fe}$ & 61 & 7.2 \\
$\mathrm{Li}$ & -- & -- \\
$\mathrm{Mg}$ & -- & -- \\
$\mathrm{Mn}$ & -- & -- \\
$\mathrm{Na}$ & 25 & 38.6 \\
$\mathrm{Sr}$ & 61 & 8.9 \\
$\mathrm{Zr}$ & 3 & 5.2 \\
Total & -- & -- \\
\hline
\end{tabular}

-- Indicates data below detection limit.

The data presented above suggest that Hydro-Sonice scrubbers are well suited for process control of submicron aerosols generated by LFCMs. The devices are not passive but require little more than steam and/or compressedair service.

\section{HEME Aerosol Scrubbing Efficiency}

High-efficiency mist eliminators are currently being tested as deep-bed, high-efficiency washable filters in LFCM off-gas processing systems. The main virtues of employing HEMEs for this purpose are that they are passive, renewable, and highly efficient. The fractional collection efficiencies for various high-efficiency aerosol scrubbing devices are graphically displayed in Figure 23 as a function of aerosol aerodynamic diameter. The HEME is warranted by the manufacturer to be 299.5\% for aerosols $13 \mu \mathrm{m}$ and nominally $100 \%$ for all others. Because HEME sub-micron performance is limited by diffusional 
capture processes, collection efficiency increases with decreasing flow rate; consequently, this device is characterized by an unlimited turndown capacity.

The manufacturers' data displayed in Figure 23 assume relatively high influent concentrations, which are more representative of HWVP and WVDP offgas conditions than those produced by the DWPF off-gas system configuration. Specifically, HEME manufacturer's performance guarantees are contingent upon HEME exhaust loadings being greater than $0.2 \mathrm{mg} / \mathrm{ACFM},{ }^{(a)}$ which is significantly greater than normal aerosol concentration in any of the off-gas technologies being considered here. Nevertheless, very high aerosol removal efficiencies have been recorded by all candidate LFCM off-gas technologies.

Experimental HEME performance characteristics were eval uated during a 90-day cold, scaled SRS melter test. During that test, various highefficiency aerosol removal devices were tested upstream of the HEME, but in

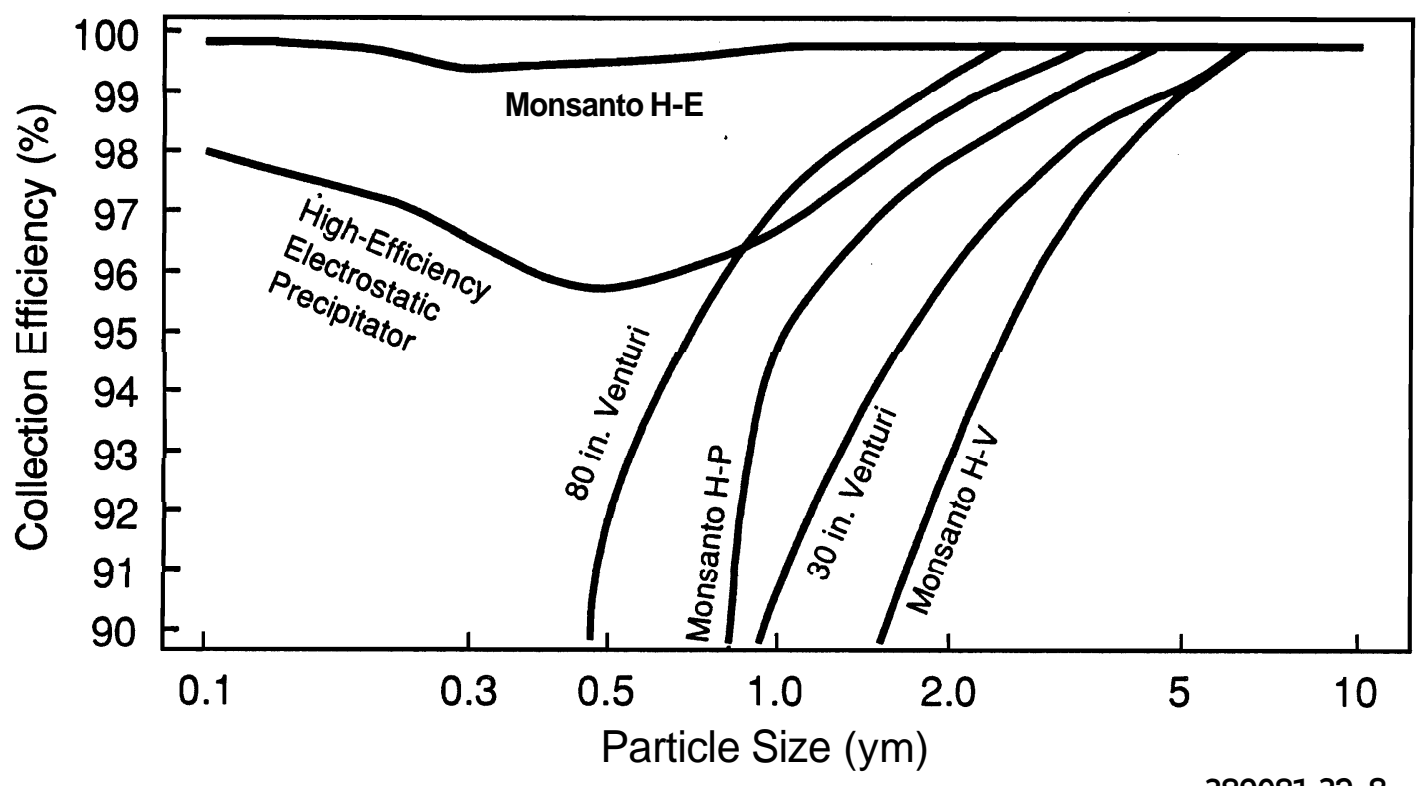

FIGURE 23. Collector Efficiency Comparisons of Various Aerosol Scrubbers by Particle Size (Monsanto Catalog IC/EC-708)

(a) Actual cubic feet per minute. 
all cases semivolatile HEV DFs >100 were observed. The HME specific DFs were also observed to increase when the efficiency of the upstream device decreased. Since the concentration and mass median diameter of HEME influent aerosols will be significantly smaller in the DWPF design than for the WDP and the HMP (due to the presence of the tandem HSSs), the above observation suggests that significantly greater HEV DFs should be achieved by the latter two off-gas systems. This was indeed found to be the case during an HMP me1ter test, PSCM-23 (Goles and Nakaoka 1990), where both mass and cesium DFs $>400$ were routinely observed. Similar results have been recorded at the PAMELA Facility at Mol, Belgium, where the spectrum of HEE influent aerosols is only modified by low-efficiency scrubbing stages.

Cascade impactors were used during the PSCM-23 test to establish the manner in which HEMEs interact with the spectrum of influent aerosols. The results of these studies are graphically illustrated in Figure 24, which displays SBS and HEME effluent (white) deposits on successive cascade impactor collection stages. In all cases deposit masses increased with decreasing stage collection diameters. These data reconfirm the previously mentioned fact that the SBS quench scrubber efficiently removes all particles with aerodynamic diameters $21 \mu \mathrm{m}$; furthermore, the data graphically illustrate that the HEME significantly reduces both the concentration and the mass median diameter of this distribution in full accordance with design expectations.

A HEME water spray whose rate is tied to noncondensible off-gas flow is used by the DWPF to continuously purge the HEME filter element of collected aerosol effluent. This operational mode is designed solely to increase service life of the filter element while eliminating or at least minimizing batch washing operations that would otherwise interrupt processing. Therefore, HEME performance is independent of active process support, and as a result this device is totally predictable and inherently more reliable than other highefficiency devices, such as the HSS or electrostatic precipitators, whose performance would drop to zero if active process support were lost.

The only important process variable that has been found to influence HEME DFs is superficial face velocity. When the HEME is operated wet and at the upper end of its operating velocity range, solution transport of effluent 


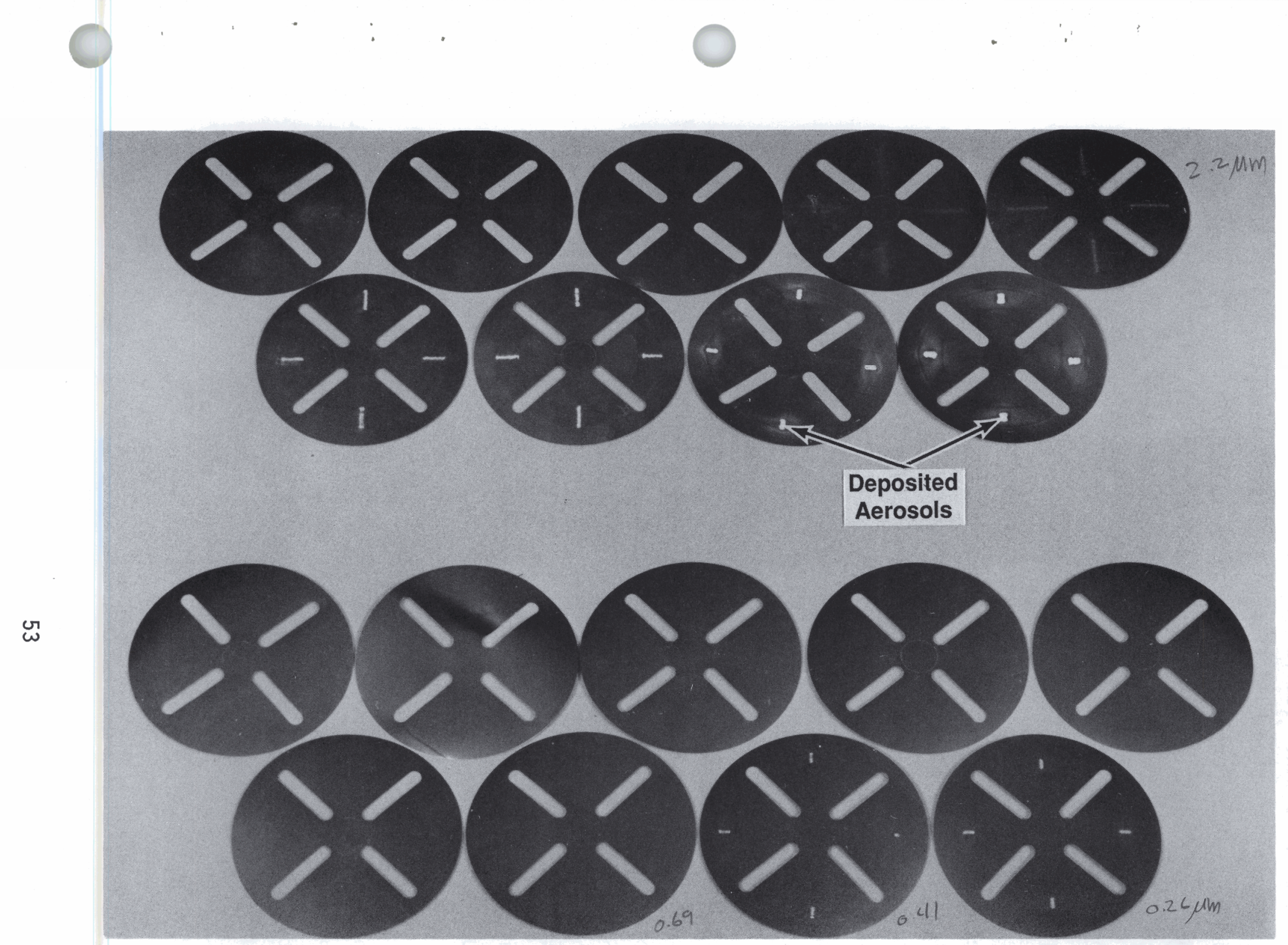

FIGURE 24. Size Distribution of Off-Gas Aerosols as Collected on Cascade Impactor Stages in SBS (top) and HEVE (bottom) Exhaust Streams. The cut points of the collection stages (left to right and from top to bottom) are $23,14,5.6,3.4,2.2, \quad 1.2,0.69,0.41$, and $0.26 \mu \mathrm{m}$. Similar sample volumes were collected in both cases. Equivalent sampling volumes were used in both cases. 
through the filter bed and subsequent re-entrainment has been found to severely I im it HEME performance (Goles and Andersen 1986). Because HEME aerosol collection is dominated by diffusional effects in all U.S. vitrification plant designs, HEVE performance has an unlimited turndown ratio; consequently, HEMEs have been sized very conservatively in all LFCM off-gas technologies to maintain face velocities of $\leq 5 \mathrm{feet} / \mathrm{minute}$.

\section{HEPA Aerosol Scrubbing Efficiency}

A dual-filter HEPA filter assembly forms the last off-gas component in the process cell. Each filter will be mounted in this assembly and individually tested, out-of-cell, to achieve a removal efficiency of $99.97 \%$ for $0.3-\mu \mathrm{m}$ aerosols. The tested and verified assembly will then be remotely installed in the LFCM's off-gas system. Since there will be no provision for in-place testing of this assembly, American National Standards Institute (ANSI) N46.1 (ANSI 1980) only allows $99.9 \%$ efficiency to be assumed for the first filter and $99 \%$ for a second series filter. Under these rules, a combined aerosol DF of $1 \times 10^{5}$ can be claimed for this assembly, although significantly higher DFs are routinely achieved. The contact-maintained HWVP HEPA located between the cell exhaust and the sand filter (although it will be subjected to in-place testing) can only be assigned a DF of 100 according to ANSI N46.1, because it is the third series HEPA filter.

\section{Sand Filter Scrubbing Efficiency}

This device, like the HEPA assembly, is designed to efficiently remove submicron aerosols from the exhaust gases passing through it. Its removal efficiency is designed and constructed to be $99.95 \%$ for $0.3-\mu \mathrm{m}$ aerosols. Because this filter is a completely passive off-gas component that requires no maintenance and cannot materially deteriorate, no real basis exists for downgrading its performance. However, because it is the fourth in a series of high-efficiency devices, it can only be assigned a DF of 100 (ANSI 1980) despite its much higher expected efficiency. 


\subsection{PROCESS VESSEL VENT SYSTEM}

Discussions of LFCM process off-gas systems have up to this point been mainly concerned with the melter off-gas component. Each of the three POG systems being considered in this report also has a process vessel ventilation (PVV) system that exhausts effluents from process tanks that support HШW and feed conditioning, secondary waste treatment, and equipment decontamination activities. The number and types of vessels making up the DWPF, WDP, and HWP process vessel vent systems is a reflection of site-specific feed processing needs and will not be discussed here. What is of primary concern to this POG evaluation is the equipment used to decontaminate the PW effluent source.

Apart from condensers and associated demisters servicing individual or groups of process vessels, the treatment systems used to abate PW header emissions for the DWPF, WWD, and HWVP are illustrated in Figures 10, 11, and 12, respectively. The DMPF deep-bed washable filter represents the simplest of these vessel treatment systems; however, it should be noted that the exhaust from DWPF evaporator tanks is serviced by two condenser-demister treatment stages before the condenser overhead exhaust is discharged to the PW header and subsequent filtration. The WDP, which has a relatively simple in-cell vessel vent system, utilizes its MOG system's HEME and HEPAs to treat quenched PW emissions. The HWP PVV consists of an SBS and dual HEPA filte $r$ assembly. These components are also used as an emergency back-up for the MOG system. Each of the PW treatment systems are clearly subsets of their corresponding MOG processing system; consequently, the strengths and liabilities of these technologies can be easily derived from previously described performance information.

Being subsets, the emission abatement capabilities of the various PVV systems are inherently inferior to their MOG counterparts. The design simplicity of the post-condenser PVV treatment systems just described reflects the fact that physical entrainment of waste-containing liquids' is the only significant contributor to PW effluent emissions, and that entrained aqueous effluent is much more easily abated than high-temperature melter emissions. 
The main sources of PVV entrainment are evaporators, tank sparges, and vessel agitators. Of these emission sources, evaporation activities are, on the average, the greatest contributor to the overall PVV source term. In all three vessel vent systems, condensers and associated demisters are used to abate entrainment 1osses. The DF expected from an evaporator-condenser combination is $>10^{4}$ (Christian and Pence 1977), and a DF of $10^{4}$ has been conservatively adopted as the design basis of DWPF vessel vent evaporation operations from SRS. This DF, however, represents the partitioning of activity between the boiled-down liquid and the collected condensate. Airborne decontamination is several orders of magnitude greater than this; consequently, the total emission rates of airborne effluents, such as ${ }^{137} \mathrm{Cs}$, from the vessel vent header are found to be $>10^{4}$ times lower than corresponding effluent release rates into the MOG treatment system.

Because of these low concentrations, it is of little consequence which of the three vessel vent systems exhibits the highest aerosol effluent abatement performance; overall POG system emission rates will be dominated and established by the MOG source term. As a result, MOG source terms can and will be used in evaluating the impacts of the three alternative POG systems upon HWVP environmental release rates of radioactive aerosols.

Radioactive gas emissions are not considered to be significant contributors to vessel vent airborne effluent, since (as previously discussed) PVV operations do not involve high temperatures nor strongly oxidizing conditions. Potential volatiles such as ${ }^{166} \mathrm{Ru}$ and ${ }^{99} \mathrm{Tc}$ are not considered to be a problem for the PVV operations so long as vessel solutions do not become too oxidizing; e.g., $6 \mathrm{M} \mathrm{H}^{+} \mathrm{NO}_{3}^{-}{ }^{-}{ }^{\text {(a) }}$ Since this cannot occur under any anticipated vessel processing conditions, volatile PV emissions of the latter two isotopes are considered to be negligible. However, volatile vessel vent emissions of ${ }^{3} \mathrm{H},{ }^{14} \mathrm{C}$, and ${ }^{129} \mathrm{I}$ will occur to some extent, but since these gaseous effluents will be totally released into the melter off-gas system during high-temperature LFCM processing, the MOG can and will be considered the only major source for stack releases of these volatile radionuclides.

(a) R. S. Ondrejcin. 1980. Volatile Ruthenium Chemistrv: An Answer to RTA 925-2. DPST-80-254, Savannah River Laboratory, Aiken, South Carolina. 


\subsection{BASES FOR PROCESS OFF-GAS SYSTEM EVALUATIONS}

The evaluation of the effectiveness of DWPF, WVDP, and HWVP process offgas systems for controlling HWVP environmental emissions is critically tied to the parameters and assumptions used in the evaluation. Consequently, the value of the POG system assessment is totally dependent on the validity and appropriateness of the data used. Unfortunately, the current state of knowledge concerning feed composition, melter behavior, and off-gas system performance is subject to change. For this reason, large safety margins are built into this evaluation to accommodate the adjustments that inevitably will occur. To properly assess the impact of parameter changes on conclusions drawn in this document, it is necessary to clearly establish the data base and the assumptions used in preparing this off-gas system assessment. These bases are discussed below.

\subsubsection{Performance Evaluation}

Atmospheric discharges of radioactive material from all operating facilities at the Hanford Site are regulated by but not limited to levels cited in the Code of Federal Regulations [40 CFR Part 61; "National Emission Standards for Hazardous Air Pollutants; Standards for Radionuclides, " U.S. Environmental Protection Agency, February $1985^{(\mathrm{a})} \mathrm{]}$. This standard limits public exposure to a yearly whole-body dose of $25 \mathrm{mrem}$ and a 75 -mrem dose to critical organs. In evaluating individual process sources that generate mixtures of radioactive effl uents, derived concentration guides (DCGs) ${ }^{(b)}$ are commonly used to assess the impact of a specific source upon the overall site emission limitations. The relationship between DCGs and $40 \mathrm{CFR}$ Part 61 dose limitations can be expressed in terms of site boundary concentrations of radionuclides by the following expression:

(a) See also Westinghouse Hanford Operations (WHC). 1991. "Standards Pertaining to Radioactive Airborne Emissions." In Environmental Compl i ance Manual, WHC-CM-4-9 (Part D), Richland, Washington.

(b) DOE 1990, Radiation Protection of the Public and the Environment, DOE 5400.5 U.S. Department of Energy, Washington, D.C. 


$$
\sum_{i} \frac{\iota_{i}}{(D C G)_{i}} \leq 1
$$

where $C_{i}=$ the concentration of radionuclide "i"

$(D C G)_{i}=$ the derived concentration guide for radionuclide "i."

This expression states that as long as the sum of radionuclide concentration ratios does not exceed 1 (the unity rule), public exposure rates will not, to first approximation, exceed regulatory limits. Although the unity rule cannot be used to establish compliance, it is useful in estimating the magnitude and relative contributions of individual emission sources upon the overall allowable site source term. If the unity rule is achieved by all site emission sources at the point of atmospheric injection (the stack), it is axiomatic that overall compliance at site boundaries will be ensured. Consequently, it will be useful to compare the effluent emission characteristics of the three candidate POG systems using stack radionuclide concentrations and corresponding DCGs according to Equation (1). By using this formalism, the relative merits of the candidate emission abatement systems can be assessed in terms of regulatory public exposure limits.

It should be noted that comparative methodology adopted above only applies to contributions of the POG source to stack releases and does not represent an evaluation of the overall plant source term. Unfortunately, at this stage of design, the hot cell source, which is part of the heating, ventilation, and cooling (HVAC) system, is not well defined, even though it could be a significant contributor to total plant releases. However, once HVAC contributions have been established and applied to Equation (1), POG and HVAC results can be added together to evaluate the overall plant releases in terms of regulatory exposure limits.

\subsubsection{Feed Composition}

The composition and physical characteristics of the melter feed stream used in this study were extracted from several sources. The reference 
radionuclide content of the HWVP waste and the gross chemical composition and physical characteristics of the melter feed were obtained from Herborn and Smith (1991).

\subsubsection{Melter and Off-Gas Performance}

Melter performance is a processing variable that depends upon testspecific operating conditions, feed composition, and processing stability. Consequently a range of values exists for total melter loss rates as well as for individual elemental losses. To complicate the matter of establ ishing reference performance values, little correlation is found to exist between the variabilities of elemental DFs for similar classes of elements. As a result there is no common basis for comparing the results of a statistically significant group of similar melter tests. The reason for this is that most elemental feed components are lost by a combination of loss mechanisms whose relative importance is dependent upon test-specific process chemistry. Because of this, the best data base that can be used to represent the HWVP operations is results obtained from pilot-scale simulations of the HWVP process. Therefore, empirical off-gas data have been utilized in.the preparation of this POG system evaluation report. Specifically, the off-gas performance data col lected during the 1985 HWVP-12/PSCM-22 melter test (Perez and Nakaoka 1986) have been used extensively for defining the melter source term. However, comparisons with other data bases are discussed when appropriate.

The justification for selecting this data base for this evaluation report is that the PSCM-22 test was stable, fairly representative of the current HWVP design, and well characterized. The later HWVP-13/PSCM-23 melter emission data (Goles and Nakaoka 1990) were not used in this study because of the unusual processing stability and exceptionally high melter DFs that distinguished that test. Because of the lower (and more conservative) melter DFs achieved during PSCM-22, equipment off-gas effluent sample sizes were significantly greater than those collected during PSCM-23, thus allowing more accurate overall characterization of the integrated off-gas processing system. Literature values or data obtained from similar LFCM tests at PNL are used when PSCM-22 data are not available. 
Although functionally similar to the HWP melter off-gas system, the composition and operating conditions of the PSCM-22 off-gas processing system were not completely representative. Most notably, the PSCM-22 off-gas system employed an EVS quench scrubber; however, previous discussions have shown the EVS and SBS to be functionally equivalent. In addition, the HEV was operated at or above the upper end of its design range. Because of these and other limitations, the criteria for assigning equipment performance values for the melter and all off-gas devices will now be discussed.

\section{Melter}

Melter performance was based on the sampling results obtained during the PSCM-22 melter test. For HWP waste components not actually present in the PSCM-22 feed stream, off-gas data obtained from comparable LFCM tests were utilized whenever appropriate, or chemical simulants were used as substitutes. A summary of all non-PSCM-22 data used in this report is presented in Appendix A.

\section{Ouench Scrubber}

The quench scrubber is the first component of the MOG system to treat the raw melter exhaust stream. It is designed to provide both off-gas quenching and effluent scrubbing functions. Assuming an operating temperature of $35^{\circ} \mathrm{C}$ and a water vapor saturated exhaust condition, a quench scrubber DF of 5 ( $80 \%$ steam recovery) has been assigned for tritium. An evaluation of the EVS used during the PSCM-22 melter test (Ruecker and Scott 1987) verified scrubber design compatibility with the conditions of the test. Since EVS and SBS technologies are functionally equivalent and PSCM-22 quench scrubber influent conditions are considered more typical than those observed during PSCM-23, the PSCM-22, EVS data base was utilized almost exclusively in establishing quench scrubber performance parameters. Exceptions are listed in Appendix A.

Idling performance values were by necessity obtained from PSCM-23 test results, as this was the only HMP melter test where off-gas equipment performance data were collected after feed processing was terminated. Because the idling condition does not involve many of the operating variables 
associated with feed processing, there is no reason to believe that PSCM-23 idling data are anything less than totally representative.

\section{Hvdrosonic Scrubber}

This MOG component is specifically designed as a high-efficiency submicron aerosol removal device. Except for DWPF test data, very little operating experience is available for this device in LFCM applications. Because the mass median diameter of the spectrum of aerosols exiting the SBS has been shown to be submicron, the DWPF basic design value of 50 for HSS decontamination of cesium will be adopted for both semi- as well as nonvolatile aerosol effluent.

\section{Hiah-Efficiency Mist El iminator}

This MOG system component is designed to remove condensed-phase aerosols from quenched LFCM exhaust streams. For the HWVP, this device serves as a demister for removing airborne water aerosols (fog) generated by the SBS and also acts as a deep-bed washable (regenerable) filter for reducing the concentrations of submicron particulate effluent. Because water vapor losses at $35^{\circ} \mathrm{C}$ have been shown'to be responsible for most of the water loading in quenched melter off-gas streams, the demisting efficiency of the HEME, although quite high, will have little impact upon the overall tritium effluent source since it is mostly in the gas phase. Consequently, a tritium of of 1 has been assigned to this device for the purposes of evaluating stack discharge concentrations of this isotope.

The airborne particulate effluent DF capabilities of this device, however, are a little more difficult to assign. As mentioned in the previous section, the HEME was operated at or above its upper velocity design specification during PSCM-22. Resultant performance measurements conducted during this test were found to be lower than design expectations, as one might expect. Subsequent testing with an appropriately sized HEME during PSCM-23 resulted in significantly higher DFs; however, the combination of low process effluent emission rates and high efficiency made an accurate assessment of performance impossible during this test, although an overall lower limit mass $\mathrm{DF}$ of 400 could be established. This value is significantly greater than the 
basic DWPF design value of 50 , as it should be, since the mass median diameter of the challenge aerosol was not reduced by HSS pretreatment as it is in the DWPF design. Because the PSCM-23 HEVE performance was found to be comparable, if not better than, DWPF test data, a more realistic although conservative HEME DF of 100 has been adopted for all chemical classes of aerosol effluents in both the HMP and WMP off-gas designs. The DWF reference design value of 40 has been retained for the DWPF HEVE due to the influence of this technology's HSS upon both the size and concentration of HEV inlet aerosols.

\section{HEPA Filter Assembly}

This off-gas component is composed of a series arrangement of two HEPA filters. This MOG device is designed specifically to efficiently remove submicron aerosols from the process exhaust stream. Each filter stage in this assembly is tested in place and is therefore capable of providing a DF of -3000 for highly penetrating $(0.3 \mu \mathrm{m})$ aerosols. Because the filter assembly is installed and maintained remotely and deterioration of gasketing material is inevitable, average filter performance will certainly be somewhat lower than the tested value. Additionally, aging and exposure to moisture and corrodants may decrease the ability of this filter assembly to maintain high DFs under unstable processing conditions. Because factors affecting HEPA filter performance are difficult to predict in a remote environment, ANSI N46.1 (1980) only allows $99.8 \%$ efficiency to be assumed for the first filter and $99 \%$ for a second subsequent series filter. Under these rules, a 'combined aerosol DF of $5 \times 10^{6}$ can be claimed for this assembly.

\section{Sand Filter}

This device, like the HEPA assembly, is designed to efficiently remove submicron aerosols from the exhaust gases passing through it. Its removal efficiency is fabricated to be $99.95 \%$ for $0.3-\mu \mathrm{m}$ aerosols. Because this filter is a completely passive off-gas component that requires no maintenance and cannot materially deteriorate, no real basis exists for downgrading its performance. However, since it is the fourth series high efficiency device to treat MOG emissions, it has been assigned a DF of 100 for the purposes of this study. 


\section{Process Vessel Ventilation Svstem}

As described in the previous section, the vessel ventilation effluent source is not a significant contributor to overall POG releases. This is primarily due to the fact that unlike the MOG, the PVV does not have to service high-temperature emission sources. Physical entrainment of waste-containing liquids, resulting from evaporation, agitation, and/or sparging processes, is the only significant contributor to PVV aerosol emissions, and these effluent emissions are much more easily dealt with than are melter-generated condensation aerosols (i .e. ${ }^{137} \mathrm{Cs}$ ). Consequently the MOG system will be considered the only significant contributor to plant releases of radionuclide aerosol.

With the possible exception of tritium, PV radioactive gas emissions $\left({ }^{14} \mathrm{C},{ }^{99} \mathrm{TC},{ }^{106} \mathrm{Ru}\right.$, and $\left.{ }^{129} \mathrm{I}\right)$ are not considered to be important sources to the stack relative to MOG contribution. This stems from the fact that the chemistry of feed and waste processing steps supported by the PV are not designed nor are they capable of forming volatile compounds of these elements at any appreciable rate, while $100 \%$ of the ${ }^{3} \mathrm{H},{ }^{14} \mathrm{C}$, and ${ }^{129} \mathrm{I}$ contained in slurry feed will be volatilized by the melter.

Vapor releases of tritium during concentration or evaporation processing steps are expected to be the largest PV source of gas phase radionuclides. Since PV system condenser temperatures will be at or below those used in the corresponding MOG system and noncondensible flows will be nominally equivalent, PVV ${ }^{3} \mathrm{H}$ losses will, at most, be equal to corresponding MOG release rates. Although water saturation of the PVV exhaust is highly unlikely, this worst-case situation would act to double POG release rates, as process tritium losses are simply governed by temperature-dependent off-gas vapor loadings, as explained earlier.

To simplify performance analysis of the three LFCM off-gas technologies, PVV releases of tritium will be included in the MOG source term since this is the only radionuclide of any potential consequence released by the PVV. Since little referable data exist regarding PV effluent emission characteristics in general and tritium releases in particular, a water-vapor-saturated PVV exhaust stream will be assumed in this evaluation--a worst- case situation. A temperature of $35^{\circ} \mathrm{C}$ will be assumed for all POG exhaust streams irrespective 
of the off-gas technology, since any design variability is due to sitespecific requirements (e.g., Hg), which are not applicable to the HWP. Consequently, the MOG HTO DF will be rated at 2.5 to reflect worst-case POG loss rates of this tritium-containing compound.

\subsection{ASSESSMENT OF POG SYSTEM PERFORMANCE}

Having established the bases for evaluating process off-gas emission rates, HWP stack emissions will be projected using DWPF, WDP, and HWP offgas designs. From the previous descriptions of these technologies and the nature of the POG source term, it is obvious that the overall performance of the HWP and WWP off-gas systems is entirely equivalent. By similar reasoning, the DWF off-gas technology will out-perform the other two systems for aerosol abatement simply by virtue of the additional high-efficiency scrubbing stage provided by the HSS. Although the HSS contributes a factor of 50 to the decontamination of the melter exhaust stream, its presence influences inlet conditions of the subsequent HEME, which reduces its efficiency (DF -100) by 40\%. Consequently, the DNF technology can reduce POG stack-re1ated emissions of radioactive aerosols by a factor of 20 over what can be achieved by the other two POG designs. The environmental importance of this difference can only be appreciated and put into perspective by comparing HWVP stack emissions with environmental regulations.

\subsubsection{Normal Radioactive Emissions}

Using the data described in the previous section, plant emissions generated by the vitrification process have been estimated based on a $100 \mathrm{~kg} / \mathrm{h}$ production rate, a noncondensible off-gas flow rate of $450 \mathrm{scfm}^{(a)}$ (Herborn and Smith 1991), and a stack dilution factor of 210 . Equation (1) was used to evaluate each off-gas technology at the point of atmospheric injection (the stack), where $C_{i}$ represents the projected stack concentration of a particular radioactive isotopic effluent. The results of the evaluation, summarized in Table 15, indicate that the HMP MOG system is fully capable of satisfying fenceline public exposure limits at the point of stack release.

(a) Standard cubic feet per minute. 
TABLE 15. Projected HMP Radioactive Effluent Releases (normal conditions)

\begin{tabular}{|c|c|c|c|c|c|c|c|c|c|c|}
\hline Element & $\begin{array}{l}\text { Curies/ } \\
\text { Gallon } \\
\end{array}$ & $\begin{array}{c}\text { Melter } \\
\text { DF }\end{array}$ & $\begin{array}{c}\text { Quench } \\
\text { DF }\end{array}$ & $\begin{array}{c}\text { HEME } \\
\text { DF }\end{array}$ & $\begin{array}{c}\text { HEPA } \\
\text { DF }\end{array}$ & $\begin{array}{c}\text { SND } \\
\text { FLTR DF } \\
\end{array}$ & Dilution & $\begin{array}{l}\text { Limit } \\
\mu \mathrm{CI} / \mathrm{ml} \\
\end{array}$ & $\begin{array}{l}\text { Fract } \\
\text { Limit } \\
\end{array}$ & $\begin{array}{c}\text { Fract } \\
\text { Limit Sum }\end{array}$ \\
\hline $\begin{array}{l}\text { H-3 } \\
\text { C-14 } \\
\text { FE-55 } \\
\text { NI-59 } \\
\text { CO-60 } \\
\text { NI-63 } \\
\text { SE-79 } \\
\text { SR-89 } \\
\text { SR-90 } \\
\text { Y-90 } \\
\text { Y-91 } \\
\text { NB-93m } \\
\text { ZR-93 } \\
\text { ZR-95 } \\
\text { NB-95 } \\
\text { TC-99 } \\
\text { RH-103m } \\
\text { RU-103 } \\
\text { RU-106 } \\
\text { RH-106 } \\
\text { PD-107 } \\
\text { AG-110m } \\
\text { CD-113m } \\
\text { IN-113111 } \\
\text { SN-113 } \\
\text { CD-115111 } \\
\text { SN-119111 } \\
\text { SN-121m } \\
\text { SN-123 } \\
\text { SN-126 } \\
\text { SB-124 } \\
\text { SB-125 } \\
\text { SB-126 } \\
\text { SB-126m } \\
\text { TE-125m } \\
\text { TE-127 } \\
\text { TE-127m } \\
\text { TE-129 } \\
\text { TE-129m } \\
\text { I-129 } \\
\text { CS-134 } \\
\text { CS-135 } \\
\text { BA-137m } \\
\text { CS-137 }\end{array}$ & 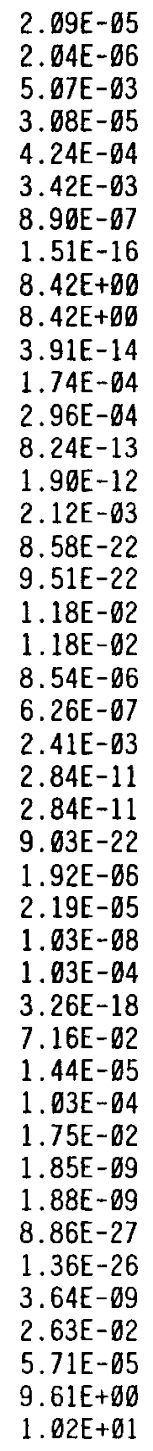 & 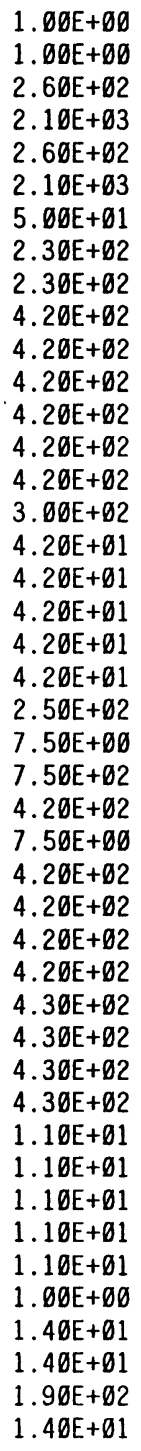 & $\begin{array}{l}2.5 \emptyset \mathrm{E}+\emptyset \emptyset \\
1 . \emptyset \emptyset \mathrm{E}+\emptyset \emptyset \\
9.2 \emptyset \mathrm{E}+\emptyset 1 \\
3.7 \emptyset \mathrm{E}+\emptyset \emptyset \\
9.2 \emptyset \mathrm{E}+\emptyset 1 \\
3.7 \emptyset \mathrm{E}+\emptyset \emptyset \\
1.4 \emptyset \mathrm{E}+\emptyset \emptyset \\
2.6 \emptyset \mathrm{E}+\emptyset 2 \\
2.6 \emptyset \mathrm{E}+\emptyset 2 \\
6.7 \emptyset \mathrm{E}+\emptyset 2 \\
6.7 \emptyset \mathrm{E}+\emptyset 2 \\
6.7 \emptyset \mathrm{E}+\emptyset 2 \\
6.7 \emptyset \mathrm{E}+\emptyset 2 \\
6.7 \emptyset \mathrm{E}+\emptyset 2 \\
6.7 \emptyset \mathrm{E}+\emptyset 2 \\
2.2 \emptyset \mathrm{E}+\emptyset 2 \\
1.4 \emptyset \mathrm{E}+\emptyset \emptyset \\
1.4 \emptyset \mathrm{E}+\emptyset \emptyset \\
1.4 \emptyset \mathrm{E}+\emptyset \emptyset \\
1.4 \emptyset \mathrm{E}+\emptyset \emptyset \\
1.4 \emptyset \mathrm{E}+\emptyset \emptyset \\
2.5 \emptyset \mathrm{E}+\emptyset 2 \\
1.4 \emptyset \mathrm{E}+\emptyset \emptyset \\
3.2 \emptyset \mathrm{E}+\emptyset 1 \\
6.7 \emptyset \mathrm{E}+\emptyset 2 \\
1.4 \emptyset \mathrm{E}+\emptyset \emptyset \\
6.7 \emptyset \mathrm{E}+\emptyset 2 \\
6.7 \emptyset \mathrm{E}+\emptyset 2 \\
6.7 \emptyset \mathrm{E}+\emptyset 2 \\
6.7 \emptyset \mathrm{E}+\emptyset 2 \\
3 . \emptyset \emptyset \mathrm{E}+\emptyset 1 \\
3 . \emptyset \emptyset \mathrm{E}+\emptyset 1 \\
3 . \emptyset \emptyset \mathrm{E}+\emptyset 1 \\
3 . \emptyset \emptyset \mathrm{E}+\emptyset 1 \\
1.4 \emptyset \mathrm{E}+\emptyset \emptyset \\
1.4 \emptyset \mathrm{E}+\emptyset \emptyset \\
1.4 \emptyset \mathrm{E}+\emptyset \emptyset \\
1.4 \emptyset \mathrm{E}+\emptyset \emptyset \\
1.4 \emptyset \mathrm{E}+\emptyset \emptyset \\
1 . \emptyset \emptyset \mathrm{E}+\emptyset \emptyset \\
1.4 \emptyset \mathrm{E}+\emptyset \emptyset \\
1.4 \emptyset \mathrm{E}+\emptyset \emptyset \\
2.9 \emptyset \mathrm{E}+\emptyset 2 \\
1.4 \emptyset \mathrm{E}+\emptyset \emptyset\end{array}$ & 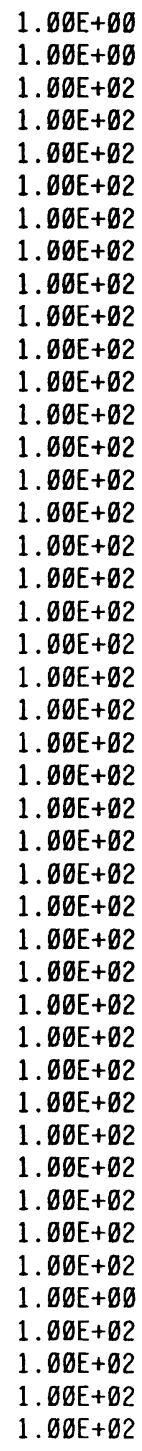 & 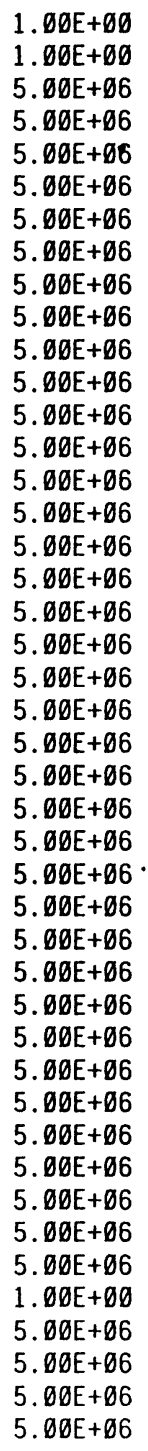 & 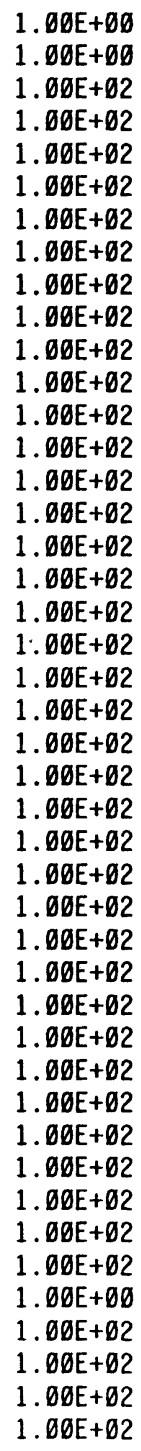 & 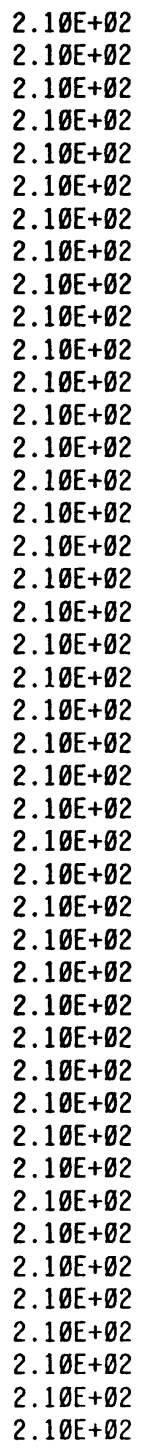 & $\begin{array}{l}1.09 \mathrm{E}-07 \\
5.00 \mathrm{E}-07 \\
5.00 \mathrm{E}-09 \\
4.00 \mathrm{E}-09 \\
8.00 \mathrm{E}-11 \\
2.00 \mathrm{E}-09 \\
1.00 \mathrm{E}-09 \\
3.00 \mathrm{E}-10 \\
9.00 \mathrm{E}-12 \\
1.00 \mathrm{E}-09 \\
3.00 \mathrm{E}-10 \\
4.00 \mathrm{E}-10 \\
4.00 \mathrm{E}-11 \\
6.00 \mathrm{E}-10 \\
3.00 \mathrm{E}-09 \\
2.00 \mathrm{E}-09 \\
3.00 \mathrm{E}-06 \\
2.00 \mathrm{E}-09 \\
3.00 \mathrm{E}-11 \\
8.00 \mathrm{E}-08 \\
9.00 \mathrm{E}-10 \\
2.00 \mathrm{E}-10 \\
8.00 \mathrm{E}-12 \\
3.09 \mathrm{E}-07 \\
1.00 \mathrm{E}-09 \\
2.00 \mathrm{E}-00 \\
1.00 \mathrm{E}-09 \\
4.00 \mathrm{E}-10 \\
1.00 \mathrm{E}-10 \\
6.00 \mathrm{E}-10 \\
1.00 \mathrm{E}-09 \\
1.00 \mathrm{E}-09 \\
4.00 \mathrm{E}-07 \\
2.00 \mathrm{E}-09 \\
4.00 \mathrm{E}-08 \\
6.06 \mathrm{E}-10 \\
2.00 \mathrm{E}-07 \\
6.00 \mathrm{E}-10 \\
7.00 \mathrm{E}-11 \\
2.00 \mathrm{E}-10 \\
3.00 \mathrm{E}-09 \\
3.00 \mathrm{E}-08 \\
4.00 \mathrm{E}-10\end{array}$ & $\begin{array}{l}1.09 \mathrm{E}-01 \\
5.33 \mathrm{E}-03 \\
1.11 \mathrm{E}-12 \\
2.59 \mathrm{E}-14 \\
5.79 \mathrm{E}-12 \\
5.75 \mathrm{E}-12 \\
3.32 \mathrm{E}-13 \\
2.20 \mathrm{E}-25 \\
4.69 \mathrm{E}-67 \\
7.82 \mathrm{E}-10 \\
1.21 \mathrm{E}-23 \\
4.04 \mathrm{E}-14 \\
6.88 \mathrm{E}-13 \\
1.28 \mathrm{E}-22 \\
5.88 \mathrm{E}-23 \\
4.26 \mathrm{E}-13 \\
1.27 \mathrm{E}-31 \\
2.11 \mathrm{E}-28 \\
1.75 \mathrm{E}-67 \\
6.56 \mathrm{E}-11 \\
4.22 \mathrm{E}-12 \\
1.31 \mathrm{E}-15 \\
7.50 \mathrm{E}-67 \\
1.03 \mathrm{E}-22 \\
2.64 \mathrm{E}-21 \\
1.12 \mathrm{E}-26 \\
8.92 \mathrm{E}-17 \\
2.63 \mathrm{E}-15 \\
2.39 \mathrm{E}-18 \\
9.57 \mathrm{E}-14 \\
1.19 \mathrm{E}-26 \\
1.45 \mathrm{E}-10 \\
2.92 \mathrm{E}-14 \\
5.22 \mathrm{E}-16 \\
1.49 \mathrm{E}-08 \\
7.85 \mathrm{E}-17 \\
5.32 \mathrm{E}-15 \\
7.52 \mathrm{E}-35 \\
\end{array}$ & $\begin{array}{l}1 . \emptyset 9 \mathrm{E}-\emptyset 1 \\
1.15 \mathrm{E}-\emptyset 1 \\
1.15 \mathrm{E}-\emptyset 1 \\
1.15 \mathrm{E}-\emptyset 1 \\
1.15 \mathrm{E}-\emptyset 1 \\
1.15 \mathrm{E}-\emptyset 1 \\
1.15 \mathrm{E}-\emptyset 1 \\
1.15 \mathrm{E}-\emptyset 1 \\
1.15 \mathrm{E}-\emptyset 1 \\
1.15 \mathrm{E}-\emptyset 1 \\
1.15 \mathrm{E}-\emptyset 1 \\
1.15 \mathrm{E}-\emptyset 1 \\
1.15 \mathrm{E}-\emptyset 1 \\
1.15 \mathrm{E}-\emptyset 1 \\
1.15 \mathrm{E}-\emptyset 1 \\
1.15 \mathrm{E}-\emptyset 1 \\
1.15 \mathrm{E}-\emptyset 1 \\
1.15 \mathrm{E}-\emptyset 1 \\
1.15 \mathrm{E}-\emptyset 1 \\
1.15 \mathrm{E}-\emptyset 1 \\
1.15 \mathrm{E}-\emptyset 1 \\
1.15 \mathrm{E}-\emptyset 1 \\
1.15 \mathrm{E}-\emptyset 1 \\
1.15 \mathrm{E}-\emptyset 1 \\
1.15 \mathrm{E}-\emptyset 1 \\
1.15 \mathrm{E}-\emptyset 1 \\
1.15 \mathrm{E}-\emptyset 1 \\
1.15 \mathrm{E}-\emptyset 1 \\
1.15 \mathrm{E}-\emptyset 1 \\
1.15 \mathrm{E}-\emptyset 1 \\
1.15 \mathrm{E}-\emptyset 1 \\
1.15 \mathrm{E}-\emptyset 1 \\
1.15 \mathrm{E}-\emptyset 1 \\
1.15 \mathrm{E}-\emptyset 1 \\
1.15 \mathrm{E}-\emptyset 1 \\
1.15 \mathrm{E}-\emptyset 1 \\
1.15 \mathrm{E}-\emptyset 1 \\
1.15 \mathrm{E}-\emptyset 1 \\
1.15 \mathrm{E}-\emptyset 1 \\
1.83 \mathrm{E}-\emptyset 1 \\
1.83 \mathrm{E}-\emptyset 1 \\
1.83 \mathrm{E}-\emptyset 1 \\
1.83 \mathrm{E}-\emptyset 1 \\
1.83 \mathrm{E}-\emptyset 1\end{array}$ \\
\hline
\end{tabular}


TABLE 15. (contd.)

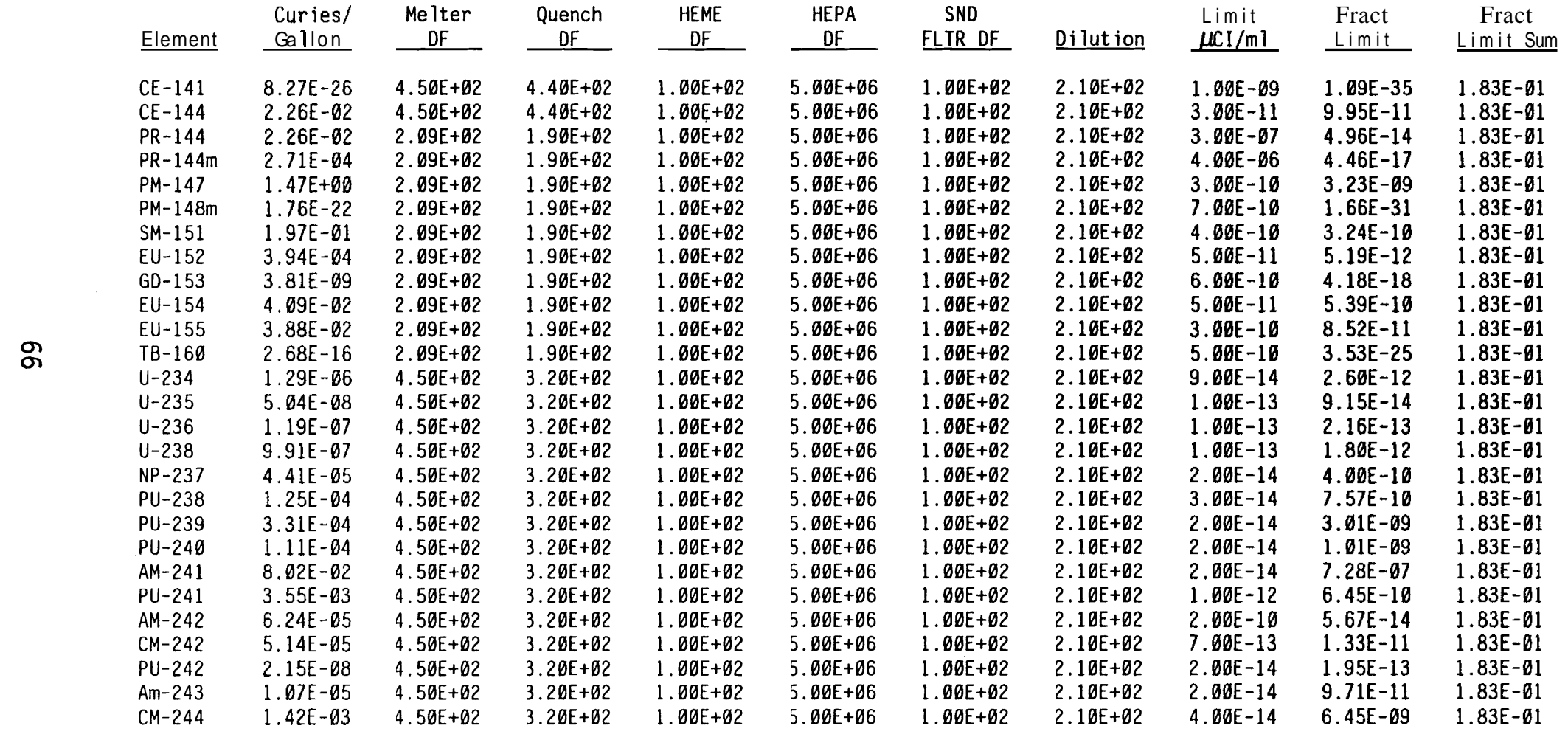


Based on preceding discussions, this conclusion suggests that the HWVP cannot affect general site compliance with $40 \mathrm{CFR} 61$ providing that the cell source term does not have a dominating influence on overall plant releases.

The HWVP POG design is actually quite conservative with regard to aerosol removal capabilities. If the gaseous effluents of ${ }^{3} \mathrm{H},{ }^{14} \mathrm{C}$, and ${ }^{129} \mathrm{I}$ are excl uded from the emission evaluation, overall MOG aerosol performance is found to be orders of magnitude greater than that required by the emissionlimiting condition described by Equation (1). When it is considered that conservatively low performance values were assigned to the HEME and HEPA filters for this assessment, it is fair to say that the HWVP MOG system provides an adequate safety margin to handle process excursions that affect overall MOG system performance. From another point of view, the high projected aerosol abatement efficiency of the POG system provides the HWVP with great latitude in accommodating particulate effluents generated from the HVAC source, whose magnitude remains to be established.

The impact of gaseous radionucl ides on allowable plant releases is clearly underscored by the dominating influence of ${ }^{3} \mathrm{H},{ }^{14} \mathrm{C}$, and ${ }^{129} \mathrm{I}$ on the fractional integrated release 1 imit defined by Equation (1). The influence of the gaseous radionuclides will not be affected by any of the three POG technologies being considered in this study. Consequently, when the fractional integrated release $1 \mathrm{imit}$ is considered for a11 radiologically important LFCM gaseous effluents, HWVP stack emissions resulting from all three process offgas technologies are found to be indistinguishable and equivalent.

In summary, of the three off-gas technologies employed in U.S. vitrification facilities, the DWPF process off-gas system was found to be $20 \mathrm{X}$ more efficient for condensed-phase aerosol removal than the functionally equivalent WVDP and HWVP systems. However, when emissions of volatile radioactive isotopes are considered, all off-gas technologies are found to be equivalent when compared on the basis of annual public exposure limits, due to the dominating influence of volatiles on the overall source term. All off-gas technologies were found to abate radioactive emissions sufficiently to meet $40 \mathrm{CFR} 61$ limits at the point of stack discharge. 


\subsubsection{Off-Normal Emissions}

Nonroutine processing conditions such as melter instabilities, increased off-gas flow rate, and failure of the MOG system and its individual components all could be expected to affect off-gas processing efficiency and resultant plant releases. The effects of each of these circumstances are discussed below.

\section{Melter Instabilities}

Unstable melter processing is one of the more common upset situations that can and will occur during vitrification campaigns. Erratic or overfeeding conditions are the most common causes for these upsets, which usually result in significant decreases in melter aerosol DFs (see Table 6). As discussed earlier, melter upsets of this type only serve to increase the concentration of large-diameter $(>1 \mu \mathrm{m})$ entrained aerosols in the MOG system. Since quench scrubbers can effectively deal with this type of effluent, overall melter-quench scrubber DFs rarely change and quenched off-gas effluent characteristics are usually not perturbed; consequently, unstable melter processing conditions will not, in general, increase stack aerosol emission rates.

Unstable processing conditions also result in erratic and sometimes convulsive melter gas generation rates, as discussed previously. Indeed, the frequency and magnitude of off-gas flow surges are often used to indicate the onset of processing difficulties. Figure $\mathbf{3}$ illustrates flow and concentration variations resulting from such an off-gas surge event. Kessler and Randall (1984) conducted a study of LFCM melter off-gas flow variations which resulted in a statistical model relating surge event magnitude with frequency of occurrence. The results of their studies showed that a $7 X$ flow surge would, on the average, occur once every 200 days while a 10X events would occur at 13-year intervals. From a very conservative standpoint, these data suggest that unstable processing conditions could increase average POG plant gaseous emission rates by as much as an order of magnitude once every processing year. Since gaseous radionuclides dominate the HWVP POG source term, the sum of fractional DCGs given by Equation (1) might be expected to exceed the (stack) unity condition over short periods ( 5 minutes) at very infrequent intervals $(\sim 1 /$ year $)$. 
Although infrequent, short-term excursions in POG flow surges could cause the DOG unity condition to be exceeded by as much as a factor of four at the stack, atmospheric dispersion will reduce the stack radionuclide concentrations by at least five orders of magnitude at site boundaries where public dose regulations are imposed (Herborn and Smith). Thus process flow surges of and by themselves cannot create unsafe public exposure conditions, but they can influence the overall site source term which is, after all, what is being regulated. The degree to which surge events affect the magnitude of the site source will not be estimated here. That estimate requires a detailed knowledge of all site sources and area meteorology and is clearly beyond the scope of this report. However, the affects of flow surges are independent of the offgas technology employed, as all systems being considered possess equivalent gaseous effluent abatement capabilities.

\section{Off-Gas System Flow Rate}

Inleakage increases in off-gas flow rates can also degrade melter offgas treatment performance. Quench scrubber performance, as discussed earlier, has been shown to be quite insensitive to flow rate changes. Similarly, HSS effluent removal mechanisms are not expected to be particularly sensitive to flow changes of this type, but HEME performance apparently is. At superficial face velocities of $>35$ feet/minute overall, HEV mass DFs have been limited to values of $-10-1 / 10$ of the HME (HWMP) assigned value at a -5 feet/minute face velocity (Goles and Anderson 1986). Although an average, sustained noncondensible flow increase of $>2 X$ is not possible in any of the off-gas technologies considered here, flow rate increases could very well degrade 1 EVE performance to some extent. But even under worst-case conditions of a $10 \mathrm{X}$ reduction in $\mathrm{EVE}$ aerosol DF, the POG source (see Table 15) would still be dominated by the releases of gaseous radionuclides $\left({ }^{14} \mathrm{C}\right)$, as they are over three orders of magnitude more influential in establishing projected plant contributions to public exposure than are radioactive aerosols. As in the case of off-gas flow surges, the above conclusion is independent of the offgas technology used. 


\section{MOG System Failure}

Failure of the primary melter off-gas system would, in general, have a varying impact upon plant emissions depending upon the POG technology employed. As previously described, the DWF POG system design has a totally redundant MOG system; thus, no changes in plant stack emission rates would occur upon switching to the auxiliary train. Failure of the MOG system in the WDP design would, on the other hand, dramatically increase plant radioactive aerosol emission rates, as there is no MOG back-up exhaust system. Without backup, WMP melter emissions would have to be vented to the process cell which, for the HWP, is unfiltered. Should this situation occur in a process cell like that of the HWP, melter airborne effluent would only be abated by settling, surface deposition, and sand filter removal mechanisms. For subrnicron condensation aerosols $\left({ }^{137} \mathrm{Cs}\right)$ the sand filter would provide the greatest barrier $(\mathrm{DF}=2000)$ between process emissions and the stack. A transient condition such as this would invariably result in unacceptable stack releases. Clearly the WWP POG system is not totally compatible with HWVP (or DWPF) process cell design.

The HWP POG system utilizes its PVV as an auxiliary melter off-gas system should the primary system fail. As described earlier, the HWP vessel vent treatment system provides all MOG treatment capabilities except for HEME filtration. All things being equal, the back-up system will provide a 100 -fold decrease in aerosol decontamination and a corresponding increase in stack emission rates. However, because LFCM processing would cease once the back-up system was employed, melter emission rates for most effluents will decrease significantly, as the effluent source term is an idling melter. On the other hand, quench scrubber DFs will decrease because idling melters predominantly produce submicron aerosols. To project the impact of this type of off-normal condition upon plant emission rates, melter and quench scrubber performance data collected during PSCM-23 idling studies were used with previously described HEPA and sand filter data to calculate radioactive stack releases, assuming that only semivolatile emissions are important and that their emission rates are comparable to those occurring under normal processing conditions. The results of these calculations, which are summarized in 
Table 16, show that MOG failure would lead to a projected 100 -fold increase in emission rates of radioactive aerosols; however, the resultant increase in POG aerosol release rates would not raise the fractional DCG-limiting sum, given by Equation (1), above the unity condition at the stack. Since the aerosol source term of the back-up MOG is projected to be only $2 \%$ of that of gaseous radionuclides released during processing, emergency use of the backup HWP MOG should not significantly increase the environmental impact of plant operations and the unity condition at the stack should be maintained.

\section{Off-Gas Equipment Failure}

Although the HWP and WDP POG designs are potentially more sensitive to process-induced changes in overall system aerosol scrubbing performance than is the DWPF, the DWPF design is much more vulnerable to disruptions or interruptions in process support services. Both the HWP and WWP systems are composed of more or less passive components. Interruption of services to any one or a combination of these devices would have no significant short-term (hours) impact upon overall system performance.

- Some DWPF off-gas components, on the other hand, require active support to function. Specifically, the performance of the EVS is critically linked to the services of a fluid recirculation pump. Pump failure would result in the

TABLE 16. Projected HMP Radioactive Effluent Releases (MOG back-up)

\begin{tabular}{|c|c|c|c|c|c|c|c|c|c|}
\hline Element & $\begin{array}{l}\text { Curies/ } \\
\text { Gallon }\end{array}$ & $\begin{array}{c}\text { Melter } \\
\text { DF }\end{array}$ & $\begin{array}{c}\text { Quench } \\
\text { DF }\end{array}$ & $\begin{array}{l}\text { HEPA } \\
\text { DF }\end{array}$ & $\begin{array}{c}\text { SND } \\
\text { FLTR DF }\end{array}$ & Dilution & $\begin{array}{r}\mathrm{Limit} \\
\mu \mathrm{CI} / \mathrm{ml}\end{array}$ & $\begin{array}{l}\text { Fract } \\
\text { Limit } \\
\end{array}$ & $\begin{array}{c}\text { Fract } \\
\text { Limit Sum }\end{array}$ \\
\hline-59 & $.08 E-05$ & $.10 E+\emptyset 3$ & $6.40 E+\emptyset 0$ & $5 . \emptyset \emptyset E+\emptyset 6$ & $1.0 \emptyset \mathrm{E}+\emptyset 2$ & $2.10 E+\emptyset 2$ & $4.00 \mathrm{E}-99$ & $1.50 \mathrm{E}-12$ & $1.50 \mathrm{E}-12$ \\
\hline & 3 & $.10 E+\emptyset 3$ & $.40 E+\emptyset \emptyset$ & $5 . \emptyset \emptyset E+\emptyset 6$ & $1 . \emptyset \emptyset E+\emptyset 2$ & $.10 E+\emptyset 2$ & 2.00E- -09 & $3.33 \mathrm{E}$ & -10 \\
\hline & $8.90 \mathrm{E}-07$ & $5 . \emptyset \emptyset \mathrm{E}+\emptyset 1$ & $1.4 \emptyset \mathrm{E}+\emptyset \emptyset$ & $5 . \emptyset \emptyset \mathrm{E}+\emptyset 6$ & $1 . \emptyset \emptyset \mathrm{E}+\emptyset 2$ & $2.1 \emptyset E+\emptyset 2$ & 1. $00 \mathrm{E}-09$ & & 10 \\
\hline & $2.12 E-03$ & $3.00 E+\emptyset 2$ & $1.50 E+\emptyset \emptyset$ & $5 . \emptyset \emptyset E+\emptyset 6$ & $1 . \emptyset \emptyset \mathrm{E}+\emptyset 2$ & $2.10 E+\emptyset 2$ & 2. $00 \mathrm{E}-09$ & & 89 \\
\hline $13 m$ & $2.41 E-\emptyset 3$ & $7.50 E+\emptyset \emptyset$ & $1.40 E+\varnothing \emptyset$ & $5 . \emptyset \emptyset E+\emptyset 6$ & $1 . \emptyset \emptyset E+\emptyset 2$ & $2.10 E+\emptyset 2$ & $8.00 E-12$ & & -05 \\
\hline & $9.03 \mathrm{E}-2$ & $7.50 E+\emptyset \emptyset$ & $2.80 E+\emptyset \emptyset$ & $5 . \emptyset 0 E+\emptyset 6$ & $1 . \emptyset 0 E+\emptyset 2$ & $2.10 E+\emptyset 2$ & 2. $00 E-10$ & & \\
\hline & 3.2 & $4.30 E+\emptyset 2$ & $\theta E+\emptyset \emptyset$ & $5.00 E+\emptyset 6$ & $1 . \emptyset \emptyset \mathrm{E}+\emptyset 2$ & $2.10 E+\emptyset 2$ & & & \\
\hline & & $4.3 \emptyset E+\emptyset 2$ & $\theta E+\emptyset \emptyset$ & $5 . \emptyset \emptyset \mathrm{E}+\emptyset 6$ & $1 . \emptyset \emptyset \mathrm{E}+\emptyset 2$ & $\emptyset E+\emptyset 2$ & 1. $00 \mathrm{E}-09$ & .67 & -05 \\
\hline & 1.4 & $4.30 E+\emptyset 2$ & $3 . \emptyset 0 E+\emptyset 1$ & $\emptyset \emptyset E+\emptyset 6$ & $\emptyset \emptyset \mathrm{E}+\emptyset 2$ & $1 \emptyset E+\emptyset 2$ & 09 & & -05 \\
\hline $\mathrm{SB}-126 \mathrm{~m}$ & 1. $\emptyset 3 \mathrm{E}-\emptyset 4$ & $4.3 \emptyset E+\emptyset 2$ & $3 . \emptyset \emptyset \mathrm{E}+\emptyset 1$ & $5 . \emptyset \emptyset E+\emptyset 6$ & $1 . \emptyset \emptyset E+\emptyset 2$ & $2.1 \emptyset E+\emptyset 2$ & $4.00 \mathrm{E}-07$ & 5.2 & -05 \\
\hline $25 \mathrm{~m}$ & $1.75 \mathrm{E}-02$ & $1.1 \emptyset \mathrm{E}+\emptyset 1$ & $1.50 E+\emptyset \emptyset$ & $5 . \emptyset \emptyset E+\emptyset 6$ & 1. $\emptyset \emptyset \mathrm{E}+\emptyset 2$ & $2.10 E+\emptyset 2$ & 2.00 & & -95 \\
\hline TE-127 & $1.85 E-\emptyset 9$ & $1.10 \mathrm{E}+\emptyset 1$ & $1.50 E+\emptyset \emptyset$ & $5.00 E+\emptyset 6$ & 1. $\emptyset \emptyset E+\emptyset 2$ & $2.10 E+\emptyset 2$ & 4. Ø0E- 08 & $7.34 E-15$ & $7.68 \mathrm{E}-05$ \\
\hline$T E-127 m$ & $1.88 E-09$ & $1.10 E+\emptyset 1$ & $1.50 E+\emptyset \emptyset$ & $5 . \emptyset 0 E+\emptyset 6$ & $1 . \emptyset \emptyset \mathrm{E}+\emptyset 2$ & $2.10 E+\emptyset 2$ & $6.00 \mathrm{E}-10$ & $4.97 E$ & $7.68 \mathrm{E}-05$ \\
\hline TE-129 & $8.86 E-27$ & $1.10 E+\emptyset 1$ & $1.50 E+\theta 0$ & $5 . \emptyset \emptyset \mathrm{E}+\emptyset 6$ & $1 . \emptyset \emptyset \mathrm{E}+\emptyset 2$ & $2.10 E+\emptyset 2$ & 2. $00 \mathrm{E}-07$ & $7.03 \mathrm{E}$ & $8 E-65$ \\
\hline $29 m$ & $1.36 \mathrm{E}-26$ & $1.10 E+\emptyset 1$ & $1.50 E+\emptyset 0$ & $5 . \emptyset \emptyset E+\emptyset 6$ & $1 . \emptyset \emptyset \mathrm{E}+\emptyset 2$ & $2.10 E+\emptyset 2$ & $6.00 \mathrm{E}-10$ & 3.60 & -65 \\
\hline & 2. $63 \mathrm{E}-02$ & $1.4 \emptyset E+\emptyset 1$ & $1.50 E+\varnothing \emptyset$ & $5 . \emptyset \emptyset E+\emptyset 6$ & $1 . \emptyset \emptyset E+\emptyset 2$ & $2.10 E+\emptyset 2$ & 2. $00 \mathrm{E}-10$ & $1.64 E-05$ & $9.32 E-05$ \\
\hline & $5.71 E-05$ & 1. $4 \emptyset E+\emptyset 1$ & $1.50 E+\emptyset \emptyset$ & $5 . \emptyset \emptyset E+\emptyset 6$ & $1 . \emptyset \emptyset \mathrm{E}+\emptyset 2$ & $2.10 E+\emptyset 2$ & $3.00 E-09$ & $2.37 \mathrm{E}$ & $9.32 E-05$ \\
\hline$-137 m$ & $9.61 E+\emptyset \emptyset$ & $1.9 \emptyset E+\emptyset 2$ & $1.50 E+\emptyset \emptyset$ & $5 . \emptyset \emptyset E+\emptyset 6$ & $1 . \emptyset \emptyset E+\emptyset 2$ & $2.10 E+\emptyset 2$ & $3.00 \mathrm{E}-08$ & $2.94 \mathrm{E}-$ & $E-05$ \\
\hline & & $1.40 \mathrm{E}+\emptyset 1$ & $1.50 \mathrm{E}+\emptyset \theta$ & $5 . \emptyset \emptyset \mathrm{E}+\emptyset 6$ & $1 . \varnothing 0 \mathrm{E}+\emptyset 2$ & $2.10 E+\emptyset 2$ & $4.00 E-10$ & $3.18 E-03$ & $3.28 E-03$ \\
\hline
\end{tabular}


loss of both quenching and scrubbing functions. The HSS scrubbing function would be similarly lost by either pump or steam service failure. A functional loss of the HSS scrubber would reduce DWPF MOG system efficiency to HWVP and WVDP POG design values which, from the standpoint of public health and safety, have been shown to be entirely adequate; however, loss of the EVS would have to be treated as an MOG failure since the functional design criteria of all subsequent devices are based upon off-gas pretreatment by the quench scrubber. Consequently, processing would have to be terminated, and the melter would have be vented to the auxiliary off-gas system. Transient releases associated with such an event would not be expected to be excessive so long as the backup system was promptly employed; however, recovery and cleanup of the primary (DWPF) MOG could produce significant cell contamination and cause a chronic increase in the plant's cell ventilation source term.

\subsubsection{Conclusion}

The off-gas performance characteristics of the DWPF, WVDP and HWVP off-gas processing systems have been evaluated under normal and off-normal processing conditions for specific application to the HWVP project. The projections are that under normal processing conditions all three systems will behave similarly and provide nominally equivalent public exposure protection due to the dominating influence of gaseous emissions of trace (curie basis) waste components $\left({ }^{3} \mathrm{H},{ }^{14} \mathrm{C}\right.$, and $\left.{ }^{129} \mathrm{I}\right)$.

The impacts of the various off-normal POG conditions upon the normal HWVP source term appearing in Table 15 have also been modeled. Of these offnormal conditions, off-gas flow surges and failure of the primary melter offgas system represent worst-case conditions relative to increasing overall plant stack emissions. Transient increases (surging) in melter gas generation rates were found to have the greatest effect on the HWVP source term. However, since all POG systems under consideration possess equivalent gaseous effluent abatement capabilities, all off-gas technologies were found to behave similarly. Because the HWVP source term is dominated by the release of gaseous radionuclides, melter off-gas surges $>3 X$ are capable of increasing stack discharges above the DCG unity condition defined by Equation 1, independent of 
the POG system employed. However atmospheric dispersion will reduce radiological stack concentrations by several orders of magnitude at site boundaries.

Unlike off-gas surging events, the environmental impact of a failed primary MOG system was found to be off-gas technology dependent. Specifically the WDP POG system is incompatible with the unfiltered HMP process cell design, as its MOG system has no back-up. The vessel vent back-up to the HMP MOG was found, on the other hand, to be entirely adequate for dealing with MOG failure conditions involving the HMP POG technology. Under worst-case conditions, a $2 \%$ increase in normal stack emissions would result from this type of failure, since gaseous radionuclide releases dominate the HWVP processing source. Idling aerosol emission rates, however, would increase by a factor of 100 , although the environmental dose associated with idling is projected to be only $2 \%$ of that associated with normal processing conditions due to the absence of radiologically important gaseous effluents. The DMPF POG technology is found to be unaffected by failure of the primary MOG system, as it possess a totally redundant MOG back-up system. With the DWF POG system neither short- (emergency venting) nor long-term (idling) use of the back-up system would impact normal stack emissions.

Although the DWF system provides equal or greater aerosol effluent decontamination under most off-normal conditions considered, projections of this study suggest that the HWVP POG design will, except when idling, provide equivalent exposure protection to the public because aerosol contributions to the overall HMP source are small. In fact, both POG systems are capable of meeting public exposure limits at the point of atmospheric injection under all normal and upset conditions except for $>3 X$ off-gas process surges. The WVDP POG, however, was found to be incompatible with the HWVP cell design under general MOG failure conditions. 



\subsection{HANDLING AND DISPOSAL OF SECONDARY WASTE}

Secondary wastes are defined as the extraneous materials generated by normal operation of the process that are not directly treated by the process. The handling and disposal of secondary wastes can result in additional costs, energy consumption, and environmental impacts. The quantity of secondary wastes is one consideration (along with the ability of the systems to meet clean-up criteria, costs, and environmental impacts) in choosing which off-gas treatment system should be employed for the process. For the purposes of this eval uation, various systems for vitrification process off-gas treatment are considered in the context of HWVP proposed guidelines. As such, the anticipated secondary wastes from the off-gas system (the melter off-gas system and vessel vent system) from a vitrification process are the following:

- sol id wastes

- contaminated clothing and supplies used in operations (e.g., process, maintenance, and repair)

- spent high-efficiency particulate air (HEPA) and other filters ( $\mathrm{NO}_{\mathrm{x}}$ removal is not considered in this study)

- failed equipment and dunnage that cannot or will not be repaired

- all piping, equipment, and instrumentation that must be decontaminated and decommissioned after use

- 1iquid wastes

- spent aqueous solutions or steam used to decontaminate the cell, piping (jumpers), and equipment for maintenance, repair, or di sposal

- low-level liquid process wastes (process condensate, scrub solutions, etc.)

- gaseous wastes

- heat released to the cell exhaust via heat transfer from the process vessels and equipment.

The excess heat from operations that is released to the cell exhaust does not significantly increase the heat load, and the three processes considered for 
this study (HWP, WDP, and DWPF) use similar heating and cooling steps in their off-gas systems. The secondary heat generation load has been calculated and is already considered in planning for the cooling needed for the plant exhaust gases. Thus, significant differences of costs are not anticipated from this source, and this element is not considered in the evaluation.

\subsection{EMISSION CONTROL TECHNOLOGIES $^{(a)}$}

\subsubsection{Relevant HMP Guidelines}

Various proposed guidelines for the handling of wastes from the HWP affect the relative importance of the two classes of secondary waste. Currently, the only available option for disposal of solid wastes is burial. It is assumed that solid wastes will be managed to reduce the volume to some reasonably low level. Most of the solid wastes considered are metal equipment and, as such, their weights are an index of the amount of solid secondary waste generated.

Low-1evel process-generated and decontamination liquid wastes wi11 both receive treatment to remove transuranics and significant radionuclides. The low-level aqueous solutions are evaporated to reduce the volume and the residuals are then grouted. The condensate from the evaporation of the lowlevel solutions is further treated by an ion exchange column until the solutions meet relevant standards for discharge to a ground column.

(a) Anon. 1988. "Chapter H. Melter Off-Gas" (pp. H-1/Rev.O through H-19/Rev.0) and "Chapter M. Process Vessel Vent" (pp. M-1/Rev. O through M-16/Rev.0) in DWFF Process and Equipment Description, DPSOP 257-1 (Information Copy), E. I - du Pont de Nemours \& Company, Inc., Aiken, South Carol ina.

T. D. Anderson. 1988. Section 2.3.6, "Melter Off-Gas Treatment" (pp. 46-64), and Section 2.3.11, "Process Vessel Vent System" (pp. 98106) in HWP Process Desian Basis Flow Sheet Document DRAFT, Rev. A, Westinghouse Hanford Company, Richland, Washington.

S. Barnes. 11/23/88 and 12/12/88. Private communications, West Valley Nuclear Services, West Valley, New York.

H. Bull. 12/12/88. Private communication, Savannah River Site, Aiken, South Carolina. 


\subsubsection{Off-Gas Treatment Svstems}

The technologies for controlling the airborne emissions from waste vitrification employed by the three facilities are described in previous sections. There are essentially two systems: System A, which is employed by the HWP and WMP; and System B, which is employed by the DWPF. The individual equipment used by these technologies is listed below.

SYSTEM A

Melter Off-Gas Svstem

Film cooler (FC)

SBS

HEE

Heater

Roughing/HEPA filte $r$

Heater (b)

Contact filter(b)

Blower/exhauster

After-cooler(b)

(a) Used by WMP only.

(b) Used by HWP only.

\begin{tabular}{l} 
Process VVS \\
\hline FC \\
SBS $(b)$ \\
Heater(b) \\
Roughing/HEPA filter $(b)$ \\
Heater(b) \\
Contact filter(b) \\
Blower/exhauster(b)
\end{tabular}

SYSTEM B

Melter Off-Gas Svstem

FC

Quencher

Off-gas condensate tank (OGCT)

SAS, two stages

Condenser

HEE

Heater

Roughing/HEPA fi门ter

Blower/exhauster

\section{Process VVS}

Condenser

Heater

Filter

Blower/exhauster 
Some of the individual components of the systems are essentially passive; they do not require mechanical movement to function (e.g., the SBS). Others are active (e.g., the EVS and SAS). Important components of both systems are the pumps that move the 1iquid from one location to another and are used for sampl ing. Pumps are mechanical items that wear with time. Pumps operated continuously wear faster than pumps that are operated intermittently (IEEE 1984). Thus, systems and components that are passive and do not utilize a large number of pumps will generate less sol id and liquid (decontamination sol utions) wastes. The important operational considerations regarding generation of secondary wastes are discussed in the next two sections.

\section{Melter Off-Gas System A}

Film Cooler. The function of the FC is to control off-gas temperatures and to efficiently transport aerosols generated by the melter to the quench scrubber. This function is accomplished by the injection of air or steam along the walls of the cooler (see Figure 25). The cooler does not itself generate liquid wastes (the steam and particulate loading are removed by subsequent pieces of equipment). It is a passive item and, if properly operated, should not wear excessively during use. Failure could occur by clogging or corrosion if improper materials enter the system or the equipment is operated under improper conditions. An average failure rate of 9,000 operating hours is assumed, and two batches of 40 liters (11 gallons) each are required to decontaminate the $\mathrm{FC}$ for repair or disposal.

Submerged-Bed Scrubber. The function of the SBS is similar to a gas scrubbing column: to remove the bulk of the entrained solids and cool the off gases. The off gases enter the SBS below a distribution plate supporting a packed bed (Figure 26). Liquids from the HEME, slurry mix evaporator condensate tank (SMECT) and the de-entrainment device on the outlet of the SBS are used to scrub gases, vapors, and particulate materials from the off gases. The liquid and gases come into contact at the gas bubble/liquid interface, where liquids and particles can be dissolved or captured by the liquid. 


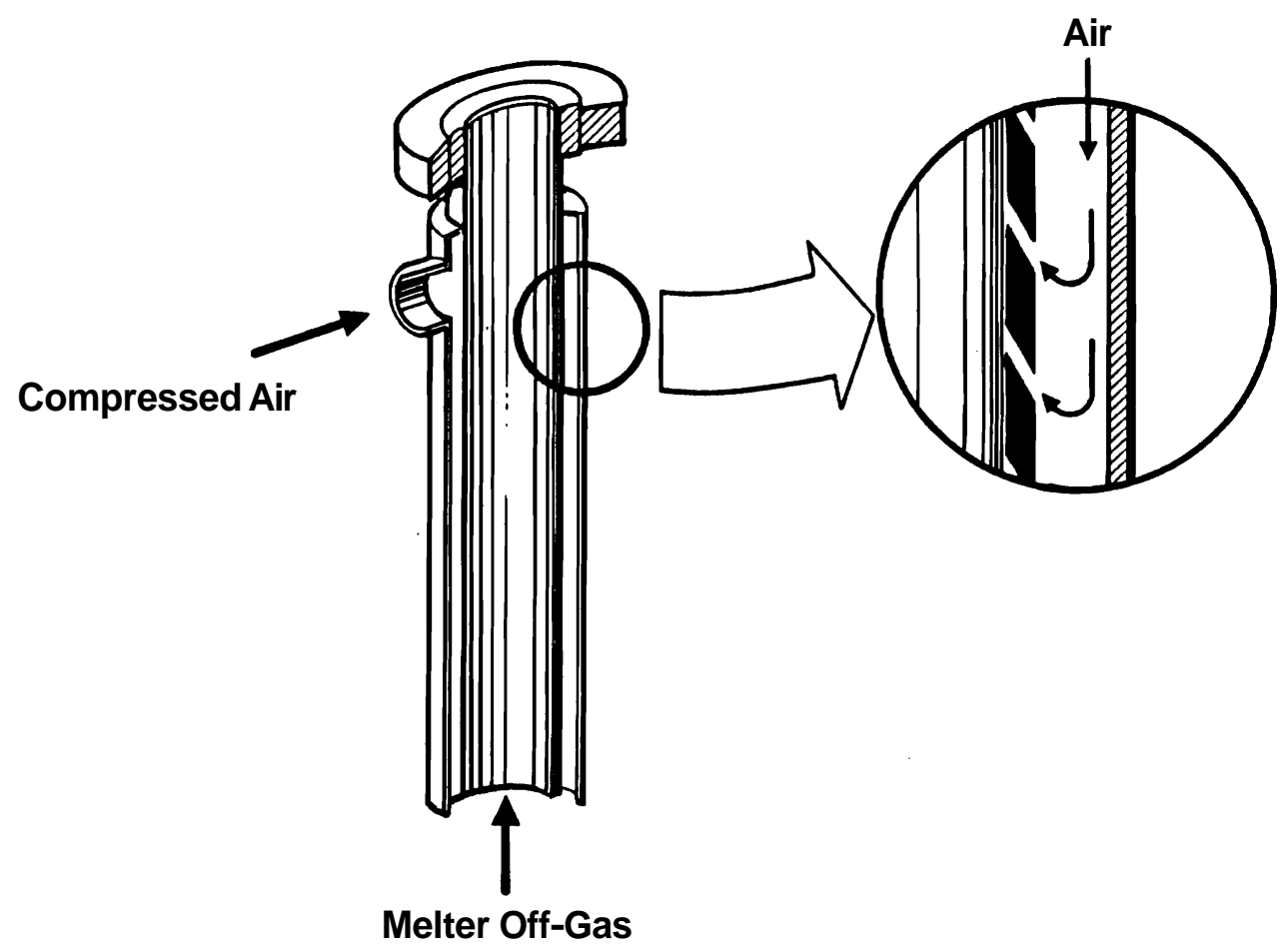

FIGURE 25. Off-Gas Film Cooler

Intimate contact between the phases is ensured by the liquid's presence in the packed bed. The SBS can also function as a condenser for vapors such as water, whose boiling temperature is considerably greater than the operating temperature of the device. To prevent accumulation of settled particulates on the bottom of the SBS scrub tank and the SBS receiver tank, sparge rings, with water as the motive fluid, will be operated periodically. An intermittently operated pump will be required for both the SBS scrub tank and the receiver tank. An average failure rate of 4000 operating hours has been assumed for pumps.

Operation of the SBS is passive: the buoyancy of the incoming gases and the differential pressure generated by the blower provide the motive force. Thus, the SBS has few, if any, moving parts and should be relatively durable. The SBS is essentially a tank with cooling coils. An average failure rate of 


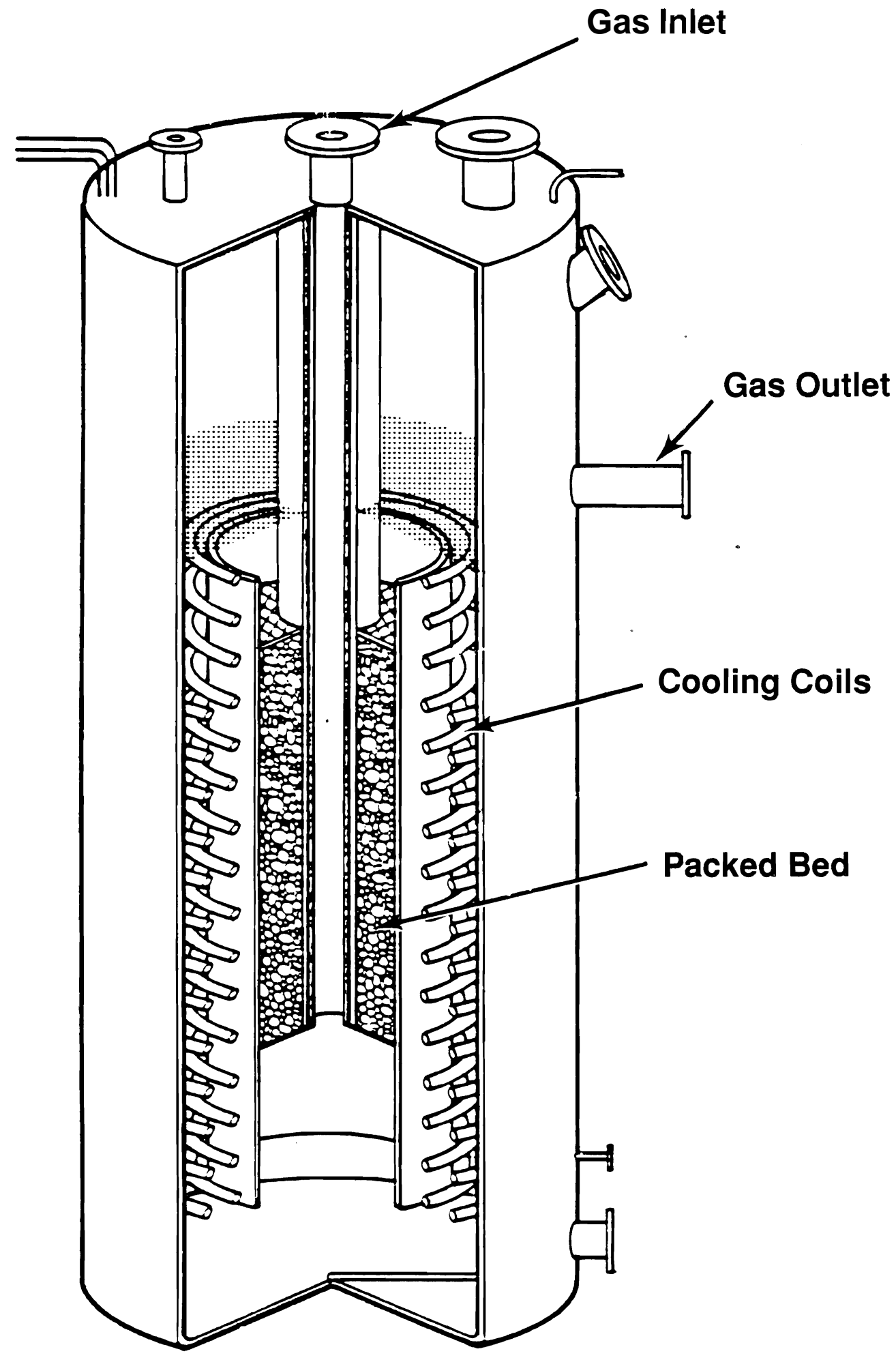

FIGURE 26. Submerged-Bed Scrubber 
300,000 hours is assumed for the SBS. Ten batches of 40 1iters (11 gallons) each are assumed to be required to decontaminate the SBS for repair or disposal.

High-Efficiencv Mist El iminator. The HEME filters proposed for System A employ a single, large, cylindrical, packed fiber bed (see Figure 19). For the HWVP system, off gases enter in the central annulus of the bed, and process water is allowed to flow down the inner face of the coarser, less densely packed fiber bed to minimize the accumulation of vapors and particulates on the bed. "Wicking" (the transmission of water through the fiber bed) is prevented by control of the water and off-gas flow rates. Excess water flows from the HEME to the SBS by gravity. A failure rate of 9,000 operating hours is assumed for the HEME, and four batches of 40 liters (11 gallons) each is assumed to be required to decontaminate the item for repair or disposal.

Heaters. To protect the roughing/HEPA filters that "polish" the off gases before emission, the off gases are heated to reduce the potential for condensation. 'In the HWVP off-gas system, an additional heater will be installed after the roughing/HEPA filters to prevent condensation in the contact HEPA filter. Heaters are relatively passive items; the heating elements are generally the 1 imiting component. An average failure rate of 18,000 operating hours is assumed and four batches of 40 liters (11 gallons) each are required to decontaminate the item for repair or disposal.

Roughing/HEPA Filters. Filters are passive items with the blower providing the motive force to move off gases through the equipment. The filters are encased in a metal package to allow remote handling. Failure is generally caused by loading of the filter media, resulting in excessive pressure differential across the filters. An average failure rate of 9,000 operating hours is assumed [a compromise between the >100,000 hours in IEEE (1984) and lower values reported elsewhere]; no decontamination is needed before disposal.

Contact HEPA Filter. In the HWVP off-gas system, a contact-maintained HEPA filter will be installed just upstream of the blower. Failure generally is caused by loading of the filter media resulting in excessive pressure 
differential across the filters. An average failure rate of 9,000 operating hours is assumed la compromise between the $>100,000$ hours in IEEE (1984) and lower values reported elsewhere]; no decontamination is needed before disposal.

Blower. Blowers are mechanical items 1ike pumps. Wear, loss of seals and glands, etc., can result in degraded performance or failure. An average failure rate of 25,000 operating hours is assumed, and no decontamination is needed before disposal. The blower is one of the last items in the off-gas treatment system and is not highly contaminated.

MOG and PV Exhauster After-Cooler. A shell and tube heat exchanger, with process cooling water on the tube side, will be used to cool the HWVP off gas (from the MOG and VV blowers) to $150^{\circ} \mathrm{F}$ or below before discharge to the Zone 1 tunnel. An average failure rate of 300,000 operating hours is assumed, and no decontamination is needed before disposal (the after-cooler is the last item in the off-gas treatment system and is not highly contaminated).

Pumps (intermittent service). Pumps are mechanical items that can wear with service. A failure rate of 4,000 hours is assumed. Pumps are used on the SBS for intermittent transfer of liquids (one pump), sparging (two pumps), and sampling (one pump). It is assumed that these four pumps are used for 1 hour each day and the average mean time between failures is 4,000 hours $\times 24=$ 96,000 hours. It is further assumed that three batches of 40 liters (11 gallons) each are required to decontaminate a pump before repair or disposal.

Process Vessel Vent System (HWVP). The individual items of equipment used for the HWVP VVS are the same as for the melter off-gas treatment system except that no HEME is used. The SBS has four pumps for liquid transfer, sparging, and sampling. The system provides surge capacity for the melter off-gas system but will not undergo conditions as rigorous. The failure rate assumed for all items except the blower are one-half the rate for melter offgas service. The steam condensation rate for the PVV SBS is approximately 50 pounds/hour and would contribute to the low-level liquid wastes from the system. 
For the WVDP WS, the ventilation off gas passes through a condenser before merging into the MOG system downstream of the SBS.

Condenser. The condenser is a shell and tube heat exchanger that removes condensibles and cools the vessel ventilation off gas from $120^{\circ} \mathrm{F}$ to about $95^{\circ} \mathrm{F}$. An average failure rate of 560,000 operating hours is assumed for the condenser in the process vessel vent system. Because of the large surface area associated with the shell and tube condenser, it has been assumed that 10 batches of 40 liters (11 gallons) each will be required to decontaminate the condenser before repair or disposal.

\section{Melter Off-Gas System B}

Film Cooler. Same as for System A.

Quencher. The quencher is a large-scale jet pump whose function is to cool the off gases. Water is pumped from the OGCT and contacts the off gases before they enter the OGCT. It is assumed that 160 pounds/hour of steam are condensed and drained into the OGCT. The quencher itself is passive, but the pump average failure rate is assumed to be 4,000 hours. It is assumed that two batches of 40 liters (11 gallons) each of decontamination solution are required before repair or disposal of this item.

Off-Gas Condensate Tank. The OGCT is a large collection tank $(11,000$ gallons) that receives condensate from the quencher, the SAS, the offgas condenser (OGC), and the HEME. It suppl ies water (cool ing coil to closedloop, chilled-water system) to the quencher and the SAS. The OGCT is agitated by a motor-driven stirrer. Pumps are used to transfer 1iquids to the SAS and condenser; excess condensate is transferred to the recycle col lection tank (RCT) and samples are provided. The OGCT is assumed to receive 950 pounds/ hour (110 gallons/hour) of low-level 1iquid effluent from all sources. The average failure rate for a process vessel is assumed to be 350,000 hours; the cooling-coil/chilier failure rate is approximately the same. It is assumed that 10 batches of 40 liters (11 gallons) each of decontamination solution are needed to clean the vessel before repair or disposal.

Steam-Atomized Scrubber. The SAS is two-stage; a single stage is shown in Figure 18. Water from the OGCT is atomized with supplied steam and mixed 
with the OGCT off gases in a horizontal mixing tube to wet and promote coalescence of particulate materials in the off gases. Particulate materials are removed from the off gases by a cyclone separator and the condensates are returned to the OGCT. The off gases pass to the OGC. It is assumed that 510 pounds/hour of steam are condensed in the SAS. The average failure rate is assumed to be 9,000 hours, and one batch of 40 liters (11 gallons) of decontamination solution is required for clean-up before repair or disposal.

Condenser. The condenser is a shell and tube heat exchanger that removes condensibles and cools the off gas exiting the SASs from $150^{\circ} \mathrm{F}$ to about $125^{\circ} \mathrm{F}$. Approximately 280 pounds/hour of water vapor is condensed within the MOG condenser. An average failure rate of 280,000 hours is projected for the condenser in the melter off-gas system. Because of the large surface area associated with the shell and tube condenser, it has been assumed that 10 batches of 40 liters (11 gallons) each will be required to decontaminate the condenser before repair or disposal.

High-Efficiency Mst E iminator. The basic function and operation of the HEME are the same as described for System A. The HEME filter proposed for the DWPF (similar to Figure 19) uses three smaller, cylindrical, packed fiber beds generally similar to those proposed for HWVP and WVDP. Off gases enter into a central plenum located at the top, hemispherical portion of the vessel. A water spray introduces water droplets into the off gases at this location. The wetted off gases and water droplets are drawn into the central annulus of the candles. The water droplets serve the same purpose as in the HWVP and WVDP HEME. Under these conditions, it appears that wicking could result. If wicking does occur, forcing the operation of the HEME in a dry mode, the failure rate for this configuration of HEME filters could be substantially higher than for those operated with water flow. An increase in the failure rate also results in a higher decontamination solution usage rate. For the purposes of this eval uation, the same failure rate and decontamination requirements are assumed for both types of HEMEs.

Heater. Same as for System A.

Roughing/HEPA Filters. Same as for System A. 
Blower. Same as for System A.

Pump (continuous service). (See System A for description of pumps.)

The failure rate is assumed to be 4,000 hours, and three batches (40 liters or 11 gallons per batch) of decontamination are required to decontaminate the pump before repair or disposal. Three continuous pumps are used on the OGCT: for the quencher, SAS, and HEME Two intermittent pumps are used on the OGCT: for liquid transfers and sampling.

Process Vessel Vent System. The PW for System B is a completely separate system. The following descriptions are for the individual items of equipment.

The formic acid vent condenser (FAVC) is a single-pass shell and tube heat exchanger. A FME is located in the center of the vessel. The HEME is normally operated dry, but a high-pressure water spray is provided to rinse material from the PEV as required. The FAVC's primary function is the removal of organics and mercury using chilled water that is circulated through the shell. However, for the purposes of this analysis, it is assumed that the FAVC is equivalent to the vessel vent condenser within the WDP vessel vent system.

The heater is the same as for System A.

The process vessel vent filter is a graded-density, packed fiberglass bed (see Figure 27). The filter consists of an outer tank with two internal, packed fiberglass beds in parallel. The inlet vapor stream enters in the middle of the vessel between the two beds and the flow splits between the parallel beds. The lower four beds are bulk 115-K Fiberglas ${ }^{\text {Th }}$ supported by screen welded to the vessel. The bed-packing densities range from 0.75 to 5.0 pounds/cubic foot. The final bed is a 1-inch-thick layer of AA Microlite Fiberglas. Again, the device is passive: off gas is drawn through the filter by differential pressure generated by the downstream blowers. The filter is sensitive to increased pressure drop across the filter from the accumulation of particulate material on or in the packed bed or additional packing of the fiberglass during operation. The filter could suffer the loss of function from bypasses resulting from the separation of the bed from its frame, 


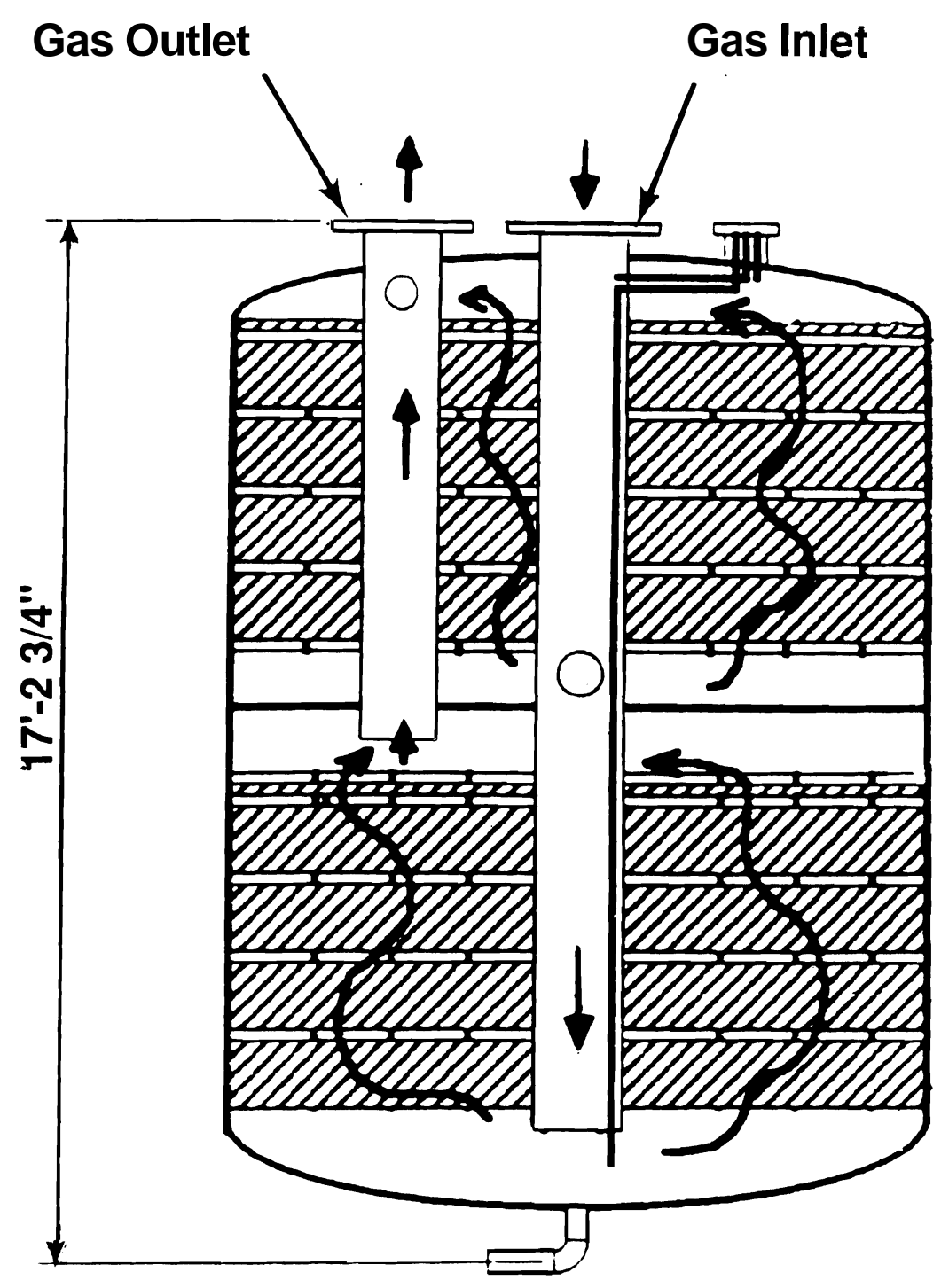

FIGURE 27. DWPF Process Vessel Vent Filter

separation of the bed supports from the vessel, or corrosion of the inlet piping. Under the proper conditions, corrosion of the filter material itself could result but does not appear to be a serious problem for the use considered here.

It does not appear that the service should be as demanding as for the filters used in the melter off-gas system. The failure rate assumed for similar items in the HWVP vessel vent system are 18,000 hours. How much longer the process vessel vent filter could remain in service is dependent upon some 
of the factors listed above. For this study, a conservative average failure rate of 18,000 hours is assumed for the process vessel vent filter. It is assumed that five batches (40 liters/batch or 11 gallons each) of decontamination solution are required to clean the filter before repair or disposal.

The blower is the same as for System A.

The intermittent pumps are required for intermittent transfer of accumulated liquid from the process vessel vent filter and to provide a highpressure rinse stream to the FAVC HEME. See the System A description.

\subsection{SECONDARY WASTE GENERATION}

The basic sources of secondary waste were given in the Introduction Section 1.0. The melter off-gas system processes are conducted remotely in cells. Under normal processing conditions, the secondary sol id wastes generated from operation of the off-gas systems will be minimal (i .e., trash with potential contamination from the operating areas, contaminated clothing) and associated with incidental operations conducted by the operating personnel. Anticontamination clothing for large facilities is usually washed and reused, producing an unknown quantity of contaminated waste liquid for the laundry and some solid waste from clothing that cannot be decontaminated satisfactorily. If the anticontamination clothing is single-use (paper or plastic that is discarded after each use), the quantity of secondary waste could increase significantly according to the number of people entering the operating areas. That number will depend upon the size of the operating force and to some lesser extent upon the number of visitors. The size of the operating force in the three proposed processes has not been finalized for these operations but will reflect the degree of manual operations performed rather than the throughput, since the process is remote and automated. Thus, assuming all three processes use the same type of handling for anticontamination clothing, the amount of solid waste from this source during routine operations will be similar.

The major differences in the solid and liquid wastes generated by the two melter off-gas systems are expected to be in the secondary waste generated 
by off-gas system equipment failures, the liquid wastes from equipment decontamination, and process liquid effluents from the condensation of moisture in the off gas. Each failure would require

- flushing of the piping and equipment to provide some level of decontamination to allow examination of the equipment (liquid waste)

- transfer to the remote decontamination cell for additional flushing of those items that are to be disposed of (liquid waste) and burial of the piping, equipment, and dunnage in a specially constructed box (solid waste)

- transfer and flushing in the remote decontamination cell and additional flushing and repair in the contact decontamination and maintenance cell (liquid waste) for those items that can be repaired. An item that must be replaced would require burial (solid waste)

- in-cell decontamination for those instances where equipment or piping failures resulted in contamination of the cell (liquid waste).

Only the impact of equipment failures is covered here.

Equipment Failure Rates. Equipment failure rates for some equipment initially proposed for the HWVP have been estimated (IEEE 1984). ${ }^{\text {(a) The }}$ failure rates assumed for this study are shown in Table 17. The number of each item used in the process is also listed.

Estimates of Solid Waste Generation by the Melter Off-Gas Systems. The weight of solid waste that could be generated by each proposed off-gas treatment system is shown in Table 18. The calculations are based on the number of each item, its failure rate, and its weight. For the purposes of this analysis, it is assumed that

(a) See also the following:

L. A. Fort. July 1987. "Letter Report - Hanford Waste Vitrification Plant Decontamination Solution Evaluation." 65651-87-046, Westinghouse Hanford Company, Richland, Washington.

F. H. Fisher, R. B. Grinde, J. C. Lavender, and R. A. Sovers. 1986. A Reliability. Availability and Maintainability Analysis of the Hanford Waste Vitrification Plant (HWVP). HWVP-11041A DRAFT, Pacific Northwest Laboratory, Richland, Washington. 
TABLE 18. Solid Waste Disposal

- System A

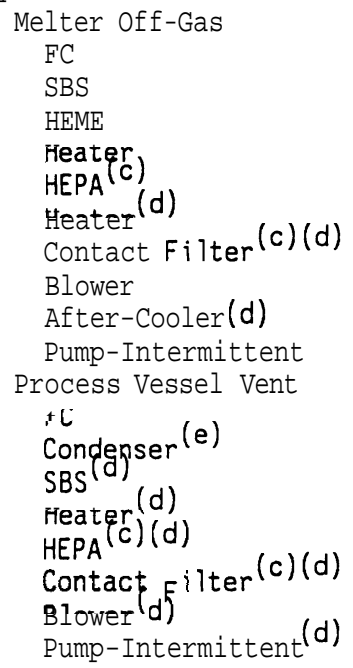

0.32

0.0097

0.32

0.16

0.97

0.16

0.97

0.12

0.0097

$\emptyset .12$

0.16

0.0052

0.0049

$\emptyset .16$

$\emptyset .49$

0.49

$\emptyset .12$

0.12

$\begin{array}{lr}0.32 & 96 \\ 0.73 & 580 \\ 0.0083 & 210 \\ 0.097 & 97 \\ 0.65 & 980 \\ 0.010 & 73 \\ 0.32 & 6,700 \\ 0.16 & 240 \\ 0.97 & 780 \\ 0.12 & 360 \\ 0.060 & 60 \\ 2.2 & 2,200 \\ & \\ 0.0052 & 180 \\ 0.081 & 120 \\ 0.49 & 10,000 \\ 0.12 & 360 \\ 0.060 & 60\end{array}$

(a) Assumes repair-to-disposal ratio of 2:1 (one-third of a 11 failures result in solid waste generation).

(b) Weight of solid waste generated per year.

(c) Each failure of filter results in disposal.

(d) HWVP only.

(e) WVDP only.

- the processes operate 24 hours/day, 365 days/year (8760 hours/year)

- one in three failures results in disposal of the item (repair-todisposal ratio of $2: 1$ ) 
- the weights listed are representative of the items that will actually be used.

Since the process and equipment design is not final, the values for failure rates and weights assumed are based upon the surveys of similar items as well as estimates by experienced individuals who developed the equipment or have used similar equipment. Without a specific design, the failure rates cannot be used to evaluate the various features that will differentiate among similar items used in different processes; thus specific design features were not considered.

The decision not to consider differences in design also impacts the estimated liquid waste generation. The estimates that were made as to the number of batches of decontamination solution required to decontaminate items of equipment after failure are based only upon the estimated approximate surface area of the items and do not consider the level of difficulty of decontamination produced by specific equipment designs.

Estimates of the weight of solid waste generated by the two waste treatment systems due to equipment failures for the melter off-gas systems are listed below. The total estimated weight of solids wastes for each component is provided in Table 19.

Estimates of Liquid Waste Generation from Melter Off-Gas Processes. The volume of liquid waste generated by each melter off-gas system is the sum of the liquid waste generated from the decontamination of failed equipment and the moisture condensed from the off gases by the treatment equipment.

The volume of decontamination solution used per year was calculated by the number of failures of each item per year multiplied by the number of batches of decontamination solution required multiplied by the volume of liquid per batch. The results are tabulated in Table 20.

The quantity of liquid effluent generated by the condensation of moisture was calculated in the energy analysis section of this report (Section 4.0). The total pounds of steam condensed divided by 8.3 pounds/gallon was used to convert the weight into volume. The treatment process for the 
TABLE 19. Annual Weight of Solid Waste Generated by Off-Gas Treatment Systems, pounds/year

- System A

$\begin{array}{lr}\text { HWP } & \\ \text { Melte r Off-Gas } & 9,100 \\ \text { Process Vessel Vent } & 1,300 \\ \text { Total } & 10,400 \\ \text { WWP } & \\ \text { Melte r Off-Gas } & 8,700 \\ \text { Process Vessel Vent } & 86 \\ \text { Total } & 8,800\end{array}$

- System B

$\begin{array}{ll}\text { DWPF } & \\ \text { Me1t e r Off-Gas } & 12,000 \\ \text { Process Vessel Vent } & 11,000 \\ \text { Total } & 23,000\end{array}$

liquid effluent and the associated energy costs are also discussed in Section 4.0. The total volume of waste from decontamination solution and condensed steam is shown in Table 21. 
TABLE 20. Off-Gas Equipment Decontamination Volumes

\begin{tabular}{|c|c|c|c|c|}
\hline & Number & Failures/yr & Batches $(a)$ & $\begin{array}{l}\text { Volume(b) } \\
\text { (gal) }\end{array}$ \\
\hline \multirow{2}{*}{\multicolumn{5}{|c|}{$\begin{array}{l}\text { System A } \\
\text { Melter off-Gas }\end{array}$}} \\
\hline & & & & \\
\hline $\mathrm{FC}$ & 1 & 0.97 & 2 & 21 \\
\hline SBS & 1 & 0.029 & 10 & 3 \\
\hline HEME & 1 & 0.97 & 4 & 43 \\
\hline Heater & 1 & 9.49 & 4 & 22 \\
\hline HEPA ${ }^{(c)}(d)$ & $i$ & 0.97 & $\emptyset$ & 0 \\
\hline Heater $(d)$ & 1 & $\emptyset .49$ & 4 & 22 \\
\hline Contact filter(c)(d) & 1 & 0.97 & $\theta$ & 0 \\
\hline Blower (e) & 1 & 9.35 & 0 & 0 \\
\hline After-Cooler(d)(e) & 1 & 0.029 & $\emptyset$ & 0 \\
\hline Pump-Intermittent & 4 & 0.36 & 3 & 12 \\
\hline \multicolumn{5}{|l|}{ Process Vessel Vent } \\
\hline FC & 1 & 0.49 & 2 & 11 \\
\hline Condegnser ${ }^{(T)}$ & 1 & 0.016 & 10 & 2 \\
\hline $\mathrm{SBS}^{(\mathrm{d})}$ & 1 & 0.015 & 10 & 2 \\
\hline Heater $(d)$ & 2 & 0.49 & 4 & 22 \\
\hline HEPA $(c)(d)$ & 1 & 0.49 & $\emptyset$ & 0 \\
\hline Contact $f j]_{t} \mathrm{rr}^{(c)(d)}$ & 1 & $\emptyset .49$ & $\emptyset$ & 0 \\
\hline Blower d) $(e ́)$ & 1 & 0.35 & $\emptyset$ & 0 \\
\hline Pump-Intermittent $(\mathrm{d})$ & 4 & 0.36 & 3 & 12 \\
\hline \multicolumn{5}{|l|}{ - System B } \\
\hline \multicolumn{5}{|l|}{ Melter off-Gas } \\
\hline FC & 1 & 0.97 & 2 & 21 \\
\hline Quencher & 1 & 0.46 & 2 & 10 \\
\hline OGCT & 1 & 0.025 & 10 & 3 \\
\hline Agitator & 1 & 0.29 & 3 & 10 \\
\hline SAS & 2 & 1.9 & 1 & 21 \\
\hline Condenser & 1 & 0.031 & 10 & 3 \\
\hline HEME & 1 & 0.97 & 4 & 43 \\
\hline \multirow{3}{*}{ HEPA $(c)$} & $i$ & 0.49 & 4 & 22 \\
\hline & 1 & $\emptyset .97$ & $\emptyset$ & $\emptyset$ \\
\hline & 1 & 0.35 & $\emptyset$ & $\emptyset$ \\
\hline Pump-Intermittent & 2 & 0.18 & 3 & 6 \\
\hline Pump-Continuous & 3 & 6.6 & 3 & 220 \\
\hline \multicolumn{5}{|l|}{ Process Vessel Vent } \\
\hline Condenser & 1 & $0 . \emptyset 16$ & 10 & 2 \\
\hline Heater & $i$ & 0.24 & 4 & 11 \\
\hline PV F ijter $(c)$ & 1 & 0.49 & $\theta$ & $\emptyset$ \\
\hline Blower $(\mathrm{e})$ & 1 & 0.35 & $\emptyset$ & $\emptyset$ \\
\hline Pump-Intermittent & 2 & 0.18 & 3 & 6 \\
\hline
\end{tabular}

\footnotetext{
(a) Batches of decontamination solution (40 1iters, 11 gallons) required per failure.

(b) Volume of decontamination waste generated per year.

(c) Roughing/HEPA filters are not assumed to be decontaminated before disposal.

(d) HWVP only..

(e) Blowers and after-cooler are assumed to be sufficiently low in contamination to allow handling without decontamination.

(f) WVDP only.
} 
TABLE 21. Annual Volume of Liquid Waste Generated by Off-Gas Treatment Systems, Gal Tons

Decontamination

Solution

- System A

HWP

Melt e r 0 f f-Gas

Process. Vessel Vent

WDP

Melter Off-Gas

Process Vessel Vent

- System B

DWPF

Melte r 0 f f-Gas

Process Vessel Vent
120

47

100

13

95,000

53,000
Process Effluent $^{(a)}$

150,000

360

19
$1,000,000$

95,000

(a) Gallons of process effluent generated by the condensation of steam introduced into the process based upon energy analysis. 


\subsection{OFF-GAS SYSTEMS ENRGY ANALYSIS}

The energy required to operate the melter and vessel ventilation off-gas systems for the HWP, DWPF, and WVDP has been estimated. Because of differences in the normal operating capacities and melter feed compositions, direct comparisons of the energy requirements of each system, operating at design conditions, would be inappropriate. Consequently, to provide a normalized comparison, the HWP off-gas source terms from the melter and vessel ventilation system were used as the source terms for the DWF and WDP off-gas systems. The energy analysis is therefore based upon the energy required to process a set quantity and composition of off-gas. Although extensive back-up off-gas treatment equipment exists, the energy consumed while maintaining the back-up equipment in standby condition was not included in the energy analysis. The extent of redundancy within the back-up systems varies significantly between the plants, and it would be inappropriate to attribute a higher energy consumption rate to a facility because it has a more elaborate back-up system.

To calculate the energy requirements' for the HWP, documented flow sheet temperatures and flow rates were taken from the HWP Detailed Design as presented in the HWP Preliminary Safety Analysis Report (PSAR) (Herborn and Smith 1991). Because of the similarities in the processes, the temperatures and flow rates from the HWVP MOG system were used to evaluate the components in the WWP MOG. Temperatures and flow rates were assigned to the DWPF offgas system components based upon the normal operating conditions of functionally equivalent HWP equipment.

The MOG systems for the HMP and WVDP are nearly identical and utilize similar equipment. Therefore, it is expected that the energy requirements of the systems will be approximately equivalent. Although the configurations of the vessel ventilation systems differ, the dissimilarities do not result in a significant difference in the overall energy requirements of the WDP and the HWVP off-gas systems.

At DWPF, an ejector-venturi quencher is used to perform a function similar to that of the submerged bed scrubbers (SBSS) at the HWVP and the WDP. 
Additionally, two SASs are employed within the DNF MOG system to remove submicron aerosols. The HWVP and the WMP MOG systems do not use SAS technology. Both the venturi quencher and the SASs require continuously operating pumps to supply water for quenching and scrubbing the off gas. Furthermore, the SASs will also use a significant quantity of steam. Because of these differences in the quenching and scrubbing systems, operation of the DWFF off-gas system will require more energy than the HMP and the WDP.

Table 22 summarizes the results of the energy analysis and provides information on the energy costs. The assumptions and bases used to generate the data in the table have been included in Appendix B. Data from Table 22 indicate that the DWPF off-gas system will require more energy and be approximately four times more expensive to operate than the HMP and the WVDP off-gas systems. The differences in energy consumption and energy costs between the HWP and the WMP are insignificant.

The primary reason that the DWF off-gas system will be approximately four times more expensive to operate than the other two systems is the use of substantial quantities of steam in the SASs. First, significant quantities of energy must be expended to generate the steam. After the steam is injected into the off gas, it must be cooled, condensed, and removed. The condensed steam from the SASs and the melter, which will be contaminated with radioactive and chemical constituents, must be treated and processed (discussed below).

The HWP and the WDP off-gas systems will use SBSs to cool and scrub melter off gas. Steam generated in the melter will be collected in the SBSs; however, no additional steam will be introduced into the off-gas systems under normal operating conditions. Furthermore, no continuously operating pumps are required for the SBSs.

From Table 22, it is apparent that the majority of off-gas system energy costs are associated with the processing of contaminated waste water. These relatively high costs will be incurred because waste water processing includes energy-intensive operations. Steam and water vapor will condense from the off-gas streams and collect in the SBSs (or in the OGCT at the DWPF). The collected waste liquid will be transferred in batches to a decontamination 
TABLE 22. Off-Gas Systems Energy Requirements and Energy Costs

\begin{tabular}{|c|c|c|c|}
\hline & HMP & DWPF & WMPP \\
\hline $\begin{array}{l}\text { Cooling--with process } \\
\text { cooling water, BTU/h } \\
\text { (annual cost, } \$ / y r)^{(a)}\end{array}$ & $\begin{array}{l}630,000 \\
(9,500)\end{array}$ & $\begin{array}{r}1,400,000 \\
(21,000)\end{array}$ & $\begin{array}{l}500,000 \\
(7,500)\end{array}$ \\
\hline $\begin{array}{l}\text { Heating, BTU/h } \\
\quad(\text { annual cost, } \$ / y r)^{(a)}\end{array}$ & $\begin{array}{r}82,000 \\
(6,700)\end{array}$ & $\begin{array}{r}41,000 \\
(3,400)\end{array}$ & $\begin{array}{r}48,000 \\
(3,900)\end{array}$ \\
\hline $\begin{array}{l}\text { Steam--for SASs, } 1 \mathrm{~b} / \mathrm{h} \\
\quad{\text { (annual cost, } \$ / y r)^{(a)}}^{(1)}\end{array}$ & $\begin{array}{l}0 \\
0\end{array}$ & $\begin{array}{r}800 \\
(61,000)\end{array}$ & $\begin{array}{l}0 \\
0\end{array}$ \\
\hline $\begin{array}{l}\text { Blower Power, hp } \\
{\text { (annual cost, } \$ / y r)^{(a)}}^{(a)}\end{array}$ & $\begin{array}{r}110 \\
(23,000)\end{array}$ & $\begin{array}{r}84 \\
(18,000)\end{array}$ & $\begin{array}{r}78 \\
(16,000)\end{array}$ \\
\hline $\begin{array}{l}\text { Pump }{ }^{(b)} \text { Power, hp } \\
\quad(\text { annual cost, } \$ / y r)^{(a)}\end{array}$ & 0 & $\begin{array}{r}9.5 \\
(2000)\end{array}$ & 0 \\
\hline $\begin{array}{l}\text { Energy for Liquid } \\
\text { Waste Processing(c) } \\
\text { waste condensate, } \quad \mathrm{b} / \mathrm{h} / \mathrm{hr} \\
\text { (annual cost, } \$ / \mathrm{yr} \text { ) }\end{array}$ & $\begin{array}{r}190 \\
(38,000)\end{array}$ & $\begin{array}{r}1040 \\
(210,000)\end{array}$ & $\begin{array}{r}230 \\
(46,000)\end{array}$ \\
\hline Total Energy Cost $(\$ / y r)^{(a)}$ & $(77,000)$. & $(320,000)$ & $(73,000)$ \\
\hline
\end{tabular}

(a) Annual cost based on $100 \%$ operational availability-- $8,760 \mathrm{~h} / \mathrm{yr}$.

(b) Continuously operating pumps are required to supply water to venturi quencher and SASs.

(c) Evaporator steam/cooling water utility costs for waste water treatment of off-gas process condensate.

waste treatment tank (DWTT). For the purposes of the energy analysis, it has been assumed that the waste water in the DWT will be heated and evaporated, and then the vapor will be condensed and cooled. Next, the cooled waste water will be transferred from the DWT to an evaporator where $90 \%$ of it will again be evaporated and then condensed and cooled. The cooled evaporator condensate, from which most contaminants will have been removed, will be further treated if necessary. The fraction of the waste in which the contaminants will be concentrated will eventually be used as grout make-up water. In summary, the processing of collected waste water will include at a minimum two evaporation and two condensation operations. Therefore, for each pound of 
waste water processed, approximately 2 pounds of process steam and 25 gallons of cooling water will be required.

The blower power necessary to maintain a vacuum on the off-gas systems is dependent upon the system components. Table 22 indicates that more blower power will be required by the HWVP than by the DWPF and WDP. The HMP and the WLP off-gas systems will incur pressure drops of approximately 36 inches (W.C.) when the off gas passes through the SBSs; however, the WVDP has only one SBS (HWP has an SBS for both the MOG and VVS systems). Less blower power will be required at the DWPF than at HMP, since a venturi quencher and SASs will be used. For the energy analysis it has been assumed that no pressure drops will be experienced with the quencher or SASs. In the actual operation of the DWPF off-gas system, vacuum increases (negative pressure drops) may be observed as the off gas passes through these two units.

The energy requirements, flow rates, temperatures, and pressures assumed for the off-gas system components of the HMP Detailed Design, the DWPF, and the WMP are summarized in Table 23. The assumptions and bases used to support the calculations from which the data in Table 23 were generated are found in Appendix B. 


\section{TABLE 23. Summary of Mass and Energy Balances for Melter Off-Gas Systems}

Component

Parameter

Melter Off-Gas System

Melter Off-Gas

Film Cooler

Pressure

Control Air

Submerged-Bed

Scrubber

Venturi

Quencher

Off-Gas

Condensate Tank

Steam-Atomized

Scrubbers

Condenser

Pre-Heater

for HEPAs

incondensible

(condensible)

temperature, ${ }^{\circ} \mathrm{F}$

pressure, psia

air, $7 b / h$

air, $1 \mathrm{~b} / \mathrm{h}$

incondensible

(condensi ble)

SBS temperature, ${ }^{\circ} \mathrm{F}$

air inleakage, scfm

cool ing, BTU/h $\mathrm{lb} / \mathrm{h}$

incondensible

(condensi ble)

quench water, gpm

water pump, hp

cooling, BTU/h

steam, 1b/h

scrub water, gpm

water pump, hp

incondensible

(condensible)

cooling, BTU/h

incondensible
HWVP

DWPF

WVDP

total flow rate, $1 \mathrm{~b} / \mathrm{h}$

$\emptyset$

total inlet flow rate, $1 \mathrm{~b} / \mathrm{h}$

inlet temperature, ${ }^{\circ} \mathrm{F}$

outlet temperature, "F

pressure drop, in. water

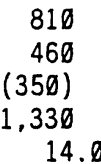

810

460
$350)$

1,330

14.9

700

700

2,210

1,860

$(350)$

530

125

125

20

36

390,000

total inlet flow rate,

inlet temperature. ${ }^{\circ} \mathrm{F}$

outlet temperature, ${ }^{\circ} \mathrm{F}$

total inleakage, $1 \mathrm{~b} / \mathrm{h}$

OGCT temperature, ${ }^{\circ} \mathrm{F}$

outlet temperature, ${ }^{\circ} \mathrm{F}$

total inlet flow rate. $1 \mathrm{~b} / \mathrm{h}$

in let temperature, ${ }^{\circ} \mathrm{F}$

outlet temperature, ${ }^{\circ} \mathrm{F}$

pressure drop, in. water

total flow rate. $1 \mathrm{~b} / \mathrm{h}$

(condensible)

inlet temperature, ${ }^{\circ} \mathrm{F}$

out let temperature, ${ }^{\circ} \mathrm{F}$

heating, BTU/h

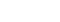

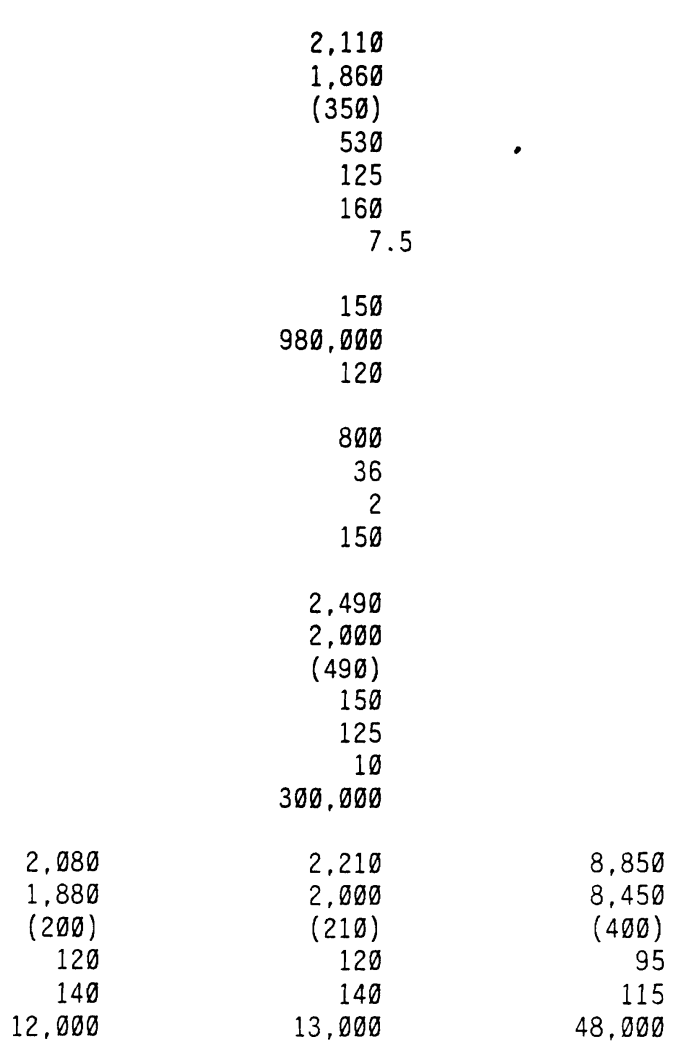


TABLE 23. (contd)

\begin{tabular}{|c|c|c|c|c|}
\hline Component & Parameter & HWVP & DWPF & WVDP \\
\hline \multicolumn{5}{|c|}{ Melter Off-Gas System - (contd) } \\
\hline $\begin{array}{l}\text { Pre-Heater } \\
\text { for Contact } \\
\text { Filter }\end{array}$ & $\begin{array}{l}\text { total flow rate, } 1 \mathrm{~b} / \mathrm{h} \\
\text { incondensible } \\
\quad \text { (condensible) } \\
\text { inlet temperature. }{ }^{\circ} \mathrm{F} \\
\text { outlet temperature, }{ }^{\circ} \mathrm{F} \\
\text { heating, BTU/h }\end{array}$ & $\begin{array}{r}2,080 \\
1,880 \\
200 \\
130 \\
160 \\
18,000\end{array}$ & & \\
\hline $\begin{array}{l}\text { Pressure Control } \\
\text { Air }\end{array}$ & total flow rate, $\mathrm{lb} / \mathrm{h}$ & 1,680 & 1,680 & 1,680 \\
\hline Blower & $\begin{array}{l}\text { total flow rate } \\
\quad \text { scfm (at } 68^{\circ} \mathrm{F} \text { ) } \\
\text { intake temperature, }{ }^{\circ} \mathrm{F} \\
\text { inlet pressure, psia } \\
\text { exhaust pressure, psia } \\
\text { required vacuum, } \\
\text { in. water } \\
\text { power, hp }\end{array}$ & $\begin{array}{r}880 \\
120 \\
11.8 \\
15.9 \\
110 \\
24\end{array}$ & $\begin{array}{l}900 \\
110 \\
12.9 \\
15.9 \\
82 \\
19\end{array}$ & $\begin{array}{r}2.400 \\
110 \\
11.9 \\
15.9 \\
110 \\
78\end{array}$ \\
\hline \multicolumn{5}{|c|}{ Vessel Ventilation System (VVS) } \\
\hline SBS & $\begin{array}{l}\text { total inlet flow rate, } \mathrm{lb} / \mathrm{h} \\
\text { incondensible } \\
\text { (condensible) } \\
\text { inlet temperature, }{ }^{\circ} \mathrm{F} \\
\text { out let temperature, }{ }^{\circ} \mathrm{F} \\
\text { pressure, drop, in. water } \\
\text { cooling, BTU/h }\end{array}$ & $\begin{array}{r}3,600 \\
3,400 \\
(200) \\
110 \\
95 \\
42 \\
66,000\end{array}$ & & \\
\hline $\begin{array}{l}\text { Formic Acid } \\
\text { Vent Condenser }\end{array}$ & $\begin{array}{l}\text { total inlet flow rate. } \mathrm{lb} / \mathrm{h} \\
\text { incondensible } \\
\text { (condensible) } \\
\text { inlet temperature, }{ }^{\circ} \mathrm{F} \\
\text { out let temperature, }{ }^{\circ} \mathrm{F} \\
\text { pressure drop, in. water } \\
\text { cooling. BTU/h }\end{array}$ & & $\begin{array}{r}2,150 \\
1,980 \\
(170) \\
120 \\
95 \\
12 \\
110,000\end{array}$ & $\begin{array}{r}2,150 \\
1,980 \\
(170) \\
120 \\
95 \\
12 \\
110,000\end{array}$ \\
\hline $\begin{array}{l}\text { Pre-Heater } \\
\text { for HEPAs }\end{array}$ & $\begin{array}{l}\text { total inlet flow rate, } \mathrm{lb} / \mathrm{h} \\
\quad \text { incondensible } \\
\text { (condensible) } \\
\text { inlet temperature. }{ }^{\circ} \mathrm{F} \\
\text { outlet temperature, }{ }^{\circ} \mathrm{F} \\
\text { heating, BTU/h }\end{array}$ & $\begin{array}{r}6.800 \\
6.570 \\
(230) \\
87 \\
102 \\
28.000\end{array}$ & $\begin{array}{r}6,770 \\
6,580 \\
(190) \\
85 \\
100 \\
28,000\end{array}$ & \\
\hline $\begin{array}{l}\text { Pre-Heater } \\
\text { for Contact } \\
\text { Filter }\end{array}$ & $\begin{array}{l}\text { total flow rate. } 1 \mathrm{~b} / \mathrm{h} \\
\quad \text { incondensible } \\
\text { (condensible) } \\
\text { inlet temperature. }{ }^{\circ} \mathrm{F} \\
\text { outlet temperature, }{ }^{\circ} \mathrm{F} \\
\text { heating, BTU/h }\end{array}$ & $\begin{array}{r}6,800 \\
6,570 \\
230 \\
96 \\
110 \\
24,000\end{array}$ & & \\
\hline $\begin{array}{l}\text { Pressure Control } \\
\text { Air }\end{array}$ & total flow rate, $\mathrm{lb} / \mathrm{h}$ & 3,900 & 3,900 & \\
\hline
\end{tabular}


TABLE 23. (contd)

\begin{tabular}{|c|c|c|c|c|}
\hline Component & Parameter & HWVP & DWPF & WVDP \\
\hline \multicolumn{5}{|c|}{ Vessel Ventilation System - (contd) } \\
\hline Blower & $\begin{array}{l}\text { total flow rate } \\
\quad \text { scfm (at } 68^{\circ} \mathrm{F} \text { ) } \\
\text { intake temperature, }{ }^{\circ} \mathrm{F} \\
\text { inlet pressure, psia } \\
\text { exhaust pressure, psia } \\
\text { required vacuum, } \\
\text { in. water } \\
\text { power, hp }\end{array}$ & $\begin{array}{r}2.400 \\
97 \\
11.5 \\
15.9 \\
120 \\
84\end{array}$ & $\begin{array}{c}2.400 \\
93 \\
12.8 \\
15.9 \\
86 \\
65\end{array}$ & \\
\hline $\begin{array}{l}\text { Off-Gas } \\
\text { After-Cooler } \\
\text { Filter }\end{array}$ & $\begin{array}{l}\text { total flow rate, } \mathrm{lb} / \mathrm{h} \\
\quad \text { incondensible } \\
\text { (condensi ble) } \\
\text { inlet temperature, }{ }^{\circ} \mathrm{F} \\
\text { out let temperature, }{ }^{\circ} \mathrm{F} \\
\text { cooling, BTU/h }\end{array}$ & $\begin{array}{r}32,000 \\
31,000 \\
(950) \\
150 \\
130 \\
170,000\end{array}$ & & \\
\hline \multicolumn{5}{|c|}{ Liquid Waste Processing } \\
\hline $\begin{array}{l}\text { Liquid Waste } \\
\text { Generation }\end{array}$ & $\mathrm{lb} / \mathrm{h}$ & 190 & 1.040 & 230 \\
\hline Steam & $1 b / h$ & $42 \theta$ & 2,300 & 510 \\
\hline Cooling & $B T U / h$ & 400,000 & $2,200,000$ & 480,000 \\
\hline
\end{tabular}





\subsection{REFERENCES}

American National Standards Institute. 1980. Guidances For Defining SafetyRelated Features of Nuclear Fuel Cycle Facilities, ANSI Standard N46.1-1980, New York, New York.

Brink, J. A. 1964. "Removal of Phosphoric Acid Mists." Chapter 5 in Gas Purification Processes, Part B, Geo. Newnes, Ltd., London.

Calvert, S., J. Goldschmid, D. Leith, and D. Mehta. 1972. "Wet Scrubber System Study." Scrubber Handbook Volume I- EPA-R2-72-118a, prepared by A.P.T., Inc., Riverside, California.

Christian, J. D., and D. T. Pence. 1977. Critical Assessment of Methods for. Treating Airborne Effluents from Hiqh-Level Waste Solidification Processes.

PNL-2486, Pacific Northwest Laboratory, Richland, Washington.

Goles, R. W., and C. M. Andersen. 1986. "LFCM Emission and Off-Gas System Performance for Feed Component Cesium." In Proceedings of the American Nuclear Society International Topical Meet ina Waste Manaqement and Decontamination and Decommissioning, September 14-18, 1986. Eds. Dr. J. M. Pope, I . M. Leonard, and E. J. Mayer. Niagara Falls, New York.

Goles, R. W., and R. K. Nakaoka. 1990. Hanford Waste Vitrification Program Pilot-Scale Ceramic Melter Test 23. PNL-7142, Pacific Northwest Laboratory, Richland, Washington.

Goles, R. W., and G. J. Sevigny. 1983a. Off-Gas Characteristics of Defense Waste Vitrification Using Liauid-Fed Ceramic Melters. PNL-4819, Pacific Northwest Laboratory, Richland, Washington.

Goles, R. W., and G. J. Sevigny. 1983b. "Off-Gas Characteristics of Liquid-Fed Joule-Heated Ceramic Melters." Proceedings of the $17 \mathrm{th}$ DOE Nuclear Air Cleaning Conference (1982: Denver, Colorado). National Technical Information Service, Springfield, Virginia.

Goles, R. W., G. J. Sevigny, and C. M. Andersen. 1991. "LFCM Processing Characteristics of Mercury." In Proceedings of the 21st DOE/NRC Nuclear Air Cleaning Conference. NUREG/CP-0116, Vol. 1, prepared by Harvard Air Cleaning Laboratory for the Nuclear Regulatory Commission.

Harris, L. S. 1966. "Fume Scrubbing with the Ejector Venturi System." Chemical Enqineering Proaress 4(62):55.

Herborn, D. I - , and D. A. Smith. 1991. Hanford Waste Vitrification Plant Preliminary Safety Analysis Report. WHC-EP-0250, Rev. 0, Westinghouse Hanford Company, Richland, Washington. 
Hilliard, R. K., J. D. McCormack, and A. K. Postma. 1981. Submerged Gravel Scrubber Demonstration as a Passive Cleaner for Containment Venting and Purqing with Sodium Aerosols. HEDL-TME-81-30, Hanford Engineering Development Laboratory, Richland, Washington.

Institute of Electrical and Electronics Engineers, Inc. 1984. IEEE Guide to the Collection and Presentation of Electrical, Electronic, Sensing Component and Mechanical Equipment Reliabilitv Data for Nuclear-Power Generating Stations, IEEE Standard 500-1984, Nuclear Power Committee, IEEE Power Engineering Society, Piscataway, New Jersey.

Kessler, J. L., and C. T. Randall. 1984. "Performance of a Large-Scale Melter and Off-Gas System Utilizing Simulated SRP DWPF Waste." In Waste Manaqement ' 84 , ed., R. G. Post, University of Arizona, Tucson, Arizona, pp. $279 \mathrm{ff}$.

McCain, J. D., and W. B. Smith. 1974. Lone Star Steel Steam-Hydro Air Cleaning Svstem Evaluation. EPA-650/2-74-028, prepared for Office of Research and Development, Environmental Protection Agency, Washington, D. C.

Owen, R. K., and A. K. Postma. 1981. "Development of a Passive, SelfCleaning Scrubber for Containment Venting Applications." In Proceedings of the 16th DOE Nuclear A ir Cleaning Conference, CONF-801038, vol. 1, ed. M. W. First. San Diego, California.

Perez, J, M., Jr., and R. K. Nakaoka. 1986. "Vitrification Testing of Simulated High-Level Radioactive Waste from Hanford." In Waste Manaqement '86. Vol. 2: High Level Waste, p. 495.

Ruecker, C. M., and P. A. Scott. 1987. Parameters Influencing the Aerosol Capture Performance of the Submerged-Bed Scrubber. PNL-6035, Pacif $i \mathrm{C}$ Northwest Laboratory, Richland, Washington.

Scott, P. A., R. W. Goles, and R. D. Peters. 1985. Technology of Off-Gas Treatment for Liquid-Fed Ceramic Melters. PNL-5446, Pacific Northwest Laboratory, Richiand, Washington.

Wright, G. T. 1983. "Efficient Particulate Scrubber for Glass Melter OffGas." DP-MS-82-42, E. I - Du Pont de Nemours and Co., Savannah River Laboratory, Aiken, South Carolina. 
APPENDIX A

SIMULANTS AND SUBSTITUTIONS 



\section{SIMULANTS AND SUBSTITUTIONS}

Equipment performance values are not always available for elements for which emission limits exist; consequently, the performance parameters derived from chemical analogs were used whenever appropriate. For the actinides, lanthanum and neodymium were used. For the transition elements, the closest adjacent or group element was utilized. Cadmium, selenium, and tellurium melter DFs were obtained from average Savannah River Site data while their MOG performances were simulated by pilot-scale ceramic melter test PSCM-22 cesium data. Specific substitutions made are listed below:

\begin{tabular}{|c|c|c|}
\hline Element & Melter & $\operatorname{EVS}^{(a)}$ \\
\hline Co & $\mathrm{Fe}$ & $\mathrm{Fe}$ \\
\hline $\mathrm{Se}$ & $\mathrm{Se}$ & Cs \\
\hline Y & $\mathrm{Zr}$ & $\mathrm{Zr}$ \\
\hline Nb & $\mathrm{Zr}$ & $\mathrm{Zr}$ \\
\hline Tc & $\mathrm{Mn}$ & Mh \\
\hline $\mathrm{Rh}$ & $\mathrm{Ru}$ & Ru \\
\hline $\mathrm{Pd}$ & Ru & Ru \\
\hline $\mathrm{Ag}$ & $\mathrm{Cu}$ & $\mathrm{Cu}$ \\
\hline $\mathrm{Cd}$ & $\mathrm{Cd}$ & Cs \\
\hline In & A1 & A1 \\
\hline Sn & $\mathrm{Zr}$ & $Z r$ \\
\hline $\mathrm{Te}$ & $\mathrm{Te}$ & Cs \\
\hline $\mathrm{Sb}$ & $\mathrm{Sb}$ & $\mathrm{Sb}$ \\
\hline $\mathrm{Pr}$ & $\mathrm{Nd}$ & $\mathrm{Nd}$ \\
\hline $\mathrm{Ce}$ & $\mathrm{Ce}$ & $\mathrm{La}$ \\
\hline $\mathrm{Pm}$ & $\mathrm{Nd}$ & $\mathrm{Nd}$ \\
\hline $\mathrm{Sm}$ & $\mathrm{Nd}$ & $\mathrm{Nd}$ \\
\hline Eu & $\mathrm{Nd}$ & $\mathrm{Nd}$ \\
\hline $\mathrm{Gd}$ & $\mathrm{Nd}$ & $\mathrm{Nd}$ \\
\hline $\mathrm{Tb}$ & $\mathrm{Nd}$ & $\mathrm{Nd}$ \\
\hline$U$ & $\mathrm{La}, \mathrm{Nd}^{(b)}$ & $\mathrm{La}, \mathrm{Nd}$ \\
\hline $\mathrm{Np}$ & $\mathrm{La}, \mathrm{Nd}$ & $\mathrm{La}, \mathrm{Nd}$ \\
\hline $\mathrm{Pu}$ & $\mathrm{La}, \mathrm{Nd}$ & $\mathrm{La}, \mathrm{Nd}$ \\
\hline Am & $\mathrm{La}, \mathrm{Nd}$ & $\mathrm{La}, \mathrm{Nd}$ \\
\hline $\mathrm{Cm}$ & $\mathrm{La}, \mathrm{Nd}$ & $\mathrm{La}, \mathrm{Nd}$ \\
\hline
\end{tabular}

(a) Ejector-venturi scrubber.

(b) La, Nd signifies averaging the data of these elements. 

APPENDIX B

ASSUMPTIONS AND BASES FOR ENERGY ANALYSIS 



\section{APPENDIX B}

\section{ASSUMPTIONS AND BASES FOR ENERGY ANALYSIS}

For the purposes of the energy analysis, the off-gas system source terms for the melter and vessel ventilation system of the Hanford Waste Vitrification Plant (HWVP) Detailed Design, as presented in the HWP Preliminary Safety Analysis Report (PSAR) (Herborn and Smith 1991) were used for Defense Waste Processing Facility (DWPF) and West Valley Demonstration Project (WVDP) to complete the energy analyses. Whenever possible, documented flowsheet conditions were used for identical and functionally similar equipment, and when information was unavailable or inappropriate, assumptions were made. The principal assumptions that were used to complete the mass and energy balances necessary to perform the energy analysis are provided in this appendix.

\section{MELTER AND VESSEL VENTILATION SYSTEM SOURCE TERMS}

The off-gas compositions and flow rates from the HWP melter and from the HMP vessel ventilation system (VVS) have been used as source terms for the off-gas systems at the HWP, the DWPF, and the WDP. Using HWP conditions for all three facilities has resulted in a normalized comparison of the energy requirements. That is, the analysis is based upon the energy necessary to process a set quantity of off gas.

In summary, the melter off-gas (MOG) flow rate used for the energy analysis for the HMP, the DWPF and the WMP was 810 pounds/hour, of which 350 pounds/hour was water vapor. Although other gases will be in the melter

off-gas stream (e.g., $\mathrm{CO}_{2}, \mathrm{NO}, \mathrm{NO}_{2}, \mathrm{SO}_{2}$ ), their concentrations are not expected to be high enough to significantly impact the results of the energy analysis. As a result, the off gas from the melter and WS have been treated as an ideal mixture of water vapor and air for energy and mass balance calculations.

For the HMP Detailed Design, the off gas from all vessels serviced by the WS will pass through the WS SBS. For the DWPF, only the vessels that 
were connected to the formic acid vent condenser (FAVC) for the HWP Reference Conceptual Design $(\mathrm{RCD})^{(\mathrm{a})}$ were assumed to be connected to the DWPF FAVC.

The remaining vessels at the DWF were assumed to be connected to the WS downstream of the FAVC.

\section{MELTER OFF-GAS SYSTEM ASSUMPTIONS}

Heat capacities used to support energy calculations were calculated by assuming that of $f$ gas behaves as an ideal mixture of air and steam. Over the temperature range of the off-gas systems, it was assumed that the specific heats of air and water vapor were constant at $0.25 \mathrm{BTU} / 1 \mathrm{~b}^{\circ} \mathrm{F}$ and $0.45 \mathrm{BTU} / 1 \mathrm{~b}^{\circ} \mathrm{F}$, respectively.

\section{Film Cooler and Pressure Control Air}

The flow rates for air to the film cooler and pressure control air were taken from the HWP PSAR. These values were also used the DWPF and the WDP. Submersed-Bed Scrubbers

A pressure drop of 36 inches of water was. assigned to the off gas flowing through the MOG submerged bed scrubbers (SBSs) for the HMP and the WMP based on the HMP PSAR. Also based on the PSAR, a pressure drop of 42 inches of water was assigned to the HMP VVS SBS based on the HMP Detailed Design PSAR material balance.

Ejector Venturi Ouencher and Steam-Atomized Scrubbers (SASs)

It has been assumed that the temperature of the of $f$ gas and water exiting the quencher at the DWPF will be $125^{\circ} \mathrm{F}$ (i.e., the same temperature at which off-gas exits the SBS at HWVP and WVDP). For the HWP ROD (which included a venturi quencher and an SAS in the melter off-gas system), the temperature of the quench water increased approximately $5^{\circ} \mathrm{F}$ during the quenching process, and the temperature of the cooled of $f$ gas and the heated quench water were equal

(a) Fluor Daniel, Inc. 1987. Reference Conceptual Design, "HWP Technical Description and Drawing," Book 3, SD-HWV-T1-007, Rev. 0, Fluor Technology Inc., Irvine, California. 
(Fluor Daniel Drawing SK-2-91285). Therefore, it has been assumed that temperature of the quench water to the inlet of the venturi quencher will be approximately $120^{\circ} \mathrm{F}$.

To quench hot melter off-gas to $125^{\circ} \mathrm{F}$, approximately 160 gallons/minute of water at $120^{\circ} \mathrm{F}$ will be required. It has been assumed that quench water will be supplied from the off-gas condensate tank (OGCT) with a vertical enclosed impeller pump at approximately $40 \mathrm{psig}$ (Ketema, Inc. 1989). Vender literature (Goulds Pumps, Inc. 1982) was used to estimate the power that will be required to operate this pump.

The off gas from the DWPF melter will be scrubbed by two SASs operated in series. For the single SAS included on the HMP RCD, steam and water were used at the rates of 0.2 pounds of steam and 4.5 pounds of water per pound of dry off gas (Fluor Daniel Drawings SK-2-90725, SK-2-91285, and SK-2-91286). For the DWPF energy analysis, the HMP ROD rates of steam and water addition were used for each of the DWPF SASs (i.e., for each pound of dry off gas, a total of 0.4 pounds of steam and 9 pounds of water will be used).

From the HWVP ROD (Fluor Daniel Drawing SK-2-91286), the steam used in the SAS was at 165 psia. Therefore, it was assumed that the steam supplied to the DWPF SASs was saturated at 165 psia. As with the venturi quencher, it was assumed that the water to the SASs will be supplied at 40 psig. The power to the water pump was also determined with the use of vendor information (Goulds Pumps, Inc. 1982).

\section{Off-Gas Condensate Tank}

The œCT at DUPF will receive liquid effluent from the venturi ejector, the SASs, the condenser, and the high-efficiency mist eliminator (HEME). For the energy analysis, it was assumed that the temperature of the liquid in the œCCT would be maintained at $120^{\circ} \mathrm{F}$.

\section{Off-Gas Condenser}

At the DWPF, the off-gas that exits from the SASs will be saturated with water vapor at approximately $150^{\circ} \mathrm{F}$. Most of this water vapor is removed from the off gas when it is cooled to $130^{\circ} \mathrm{F}$ in the condenser. The pressure drop across the condenser was assumed to be 10 inches of water. 
Hiqh-Efficiency Particulate Air (HEPA) Filter Preheaters

To ensure that the off-gas passing through the HEPA filters does not condense, it first passes through electrical resistance heaters. For the HWP, the heater must raise the temperature of the off gas so that its relative

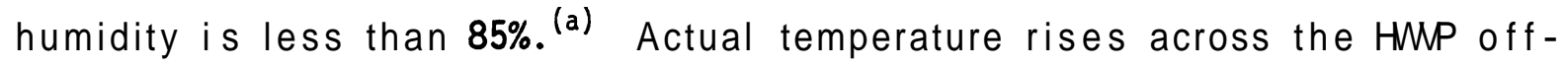
gas system were taken from the HMP Detailed Design PSAR.

\section{$\underline{0 f f-G a s ~ B l o w e r s}$}

It has been assumed that all melter off-gas and VVS blowers for the three facilities will be rotary positive blowers driven by fixed-speed motors.

Furthermore, it has also been assumed that the blowers will be sized for $20 \%$ more off gas than the nominal off-gas flow.

To calculate the energy required by blowers, vender information (Dresser Industries, Inc. 1987 and 1989) was used to estimate the horsepower. This value was then divided by 0.8 to account for the decrease in efficiency as a result of oversizing the blower motor.

The vacuum that must be maintained at the blower inlet is a sum of the pressure drops through the off-gas system components and the pressure difference between the melter and the melter cell. For the energy analysis, the pressure differential across the blowers were taken from the HMP Detailed Design (Herborn and Smith 1991). Differences between the pressure drops in three systems were accounted for by adding or subtracting the individual pressure drops across plant-specific off-gas scrubbing components.

\section{VESSEL VENTILATION SYSTEM ASSUMPTIONS}

The HMP vessel ventilation system consists of an SBS, a heater, roughing/HEPA filters, another heater, a contact HEPA filter, and a blower. The assumptions for these components (temperatures, air-inleakage rates, and pressure drops) are identical to those discussed for the melter off-gas systems.

(a) Westinghouse Hanford Company. 1990. "Hanford Waste Vitrification Plant Technical Data Package." SD-HWV-DP-001, Rev. 5, Section 3, Item 600. Richland, Washington. 
The WS at the DWF consists of a condenser (FAVC), a heater, a filter, and a blower. A HEVE is contained within the FAVC; therefore, the pressure drop across the FAVC was assumed to be 12 inches of water. The filter specified for the DWF WS appears to have been designed to satisfy site-specific conditions. To provide for a normalized energy analysis, the filter was replaced with roughing/HEPA filters.

The WS at the WDP consists of a single condenser. Following the condenser, the WS is tied into the melter off-gas system. The off gas from the WS and melter off-gas mix before entering the MOG HEME. The outlet temperature from the WS condenser is assumed to be $95^{\circ} \mathrm{F}$.

\section{LIOUID EFFLUENT PROCESSING}

Steam generated in the melter or injected into the off-gas system will be contaminated to some extent with radioactive and chemical constituents. Consequently, condensed steam that collects within the off-gas systems must be treated and processed before it can be discarded. Decontamination solutions must also undergo some processing; however, the annual quantities of decontamination solution generated are insignificant when compared to process effluent annual quantities (see Table 21 of the main report).

For the HWP, it has been assumed that liquid effluent that collects in the SBS will be transferred in batches to the decontamination waste treatment tank (DWTT). The liquid effluent will enter the DWT at $120^{\circ} \mathrm{F}$ and then will be heated and evaporated. (For the energy analysis it has been assumed that $100 \%$ of the SBS liquid effluent will evaporate.) The vapor will be condensed and cooled to $125^{\circ} \mathrm{F}$. Next, the condensate will be transferred to the $242-\mathrm{A}$ evaporator where $90 \%$ of it will be evaporated again. This relatively clean vapor will be condensed and cooled to $125^{\circ} \mathrm{F}$ before it is further treated or discarded. The remaining $10 \%$ of the liquid effluent in the $242-\mathrm{A}$ evaporator will be cooled to $125^{\circ} \mathrm{F}$ and eventually used as grout make-up water.

For the energy analysis, it was assumed that 100 psia process steam would be used to facilitate the required evaporations. Assuming that the evaporators are $90 \%$ efficient and $100 \%$ of the steam condenses and leaves the heating coils as water at $150^{\circ} \mathrm{F}$, approximately 2 pounds of steam will be required to 
process each pound of liquid effluent. It was also assumed that the process cool ing water would be available at $100^{\circ} \mathrm{F}$ to cool and condense the vaporized effluent. If $i t$ is assumed that cooling water exits from the condensers at $110 \circ \mathrm{F}$, then approximately 25 gallons of cooling water will be required for each pound of liquid effluent.

It has been assumed that all three facilities will use similar processes for effluent treatment. Therefore, the rates of steam and cooling water to process liquid effluent (given above) have been used to calculate the energy requirements for liquid waste treatment for the three off-gas systems.

\section{COST ASSUMPIIONS}

Utility cost data were used to estimate the operational energy costs of the off-gas systems. Motors (for pumps and blowers) and heaters were assumed to be powered by electricity. It was assumed that the process cooling water (not chilled) would be used for all cooling operations. Estimates used to calculate the utility costs, in 1991 dollars, are provided in Table B.1.

TABLE B.1. Utility Costs Estimates

Utility

Electricity

Steam

Cooling Water
Unit Price

$\$ 0.032 / \mathrm{kWh}^{(\mathrm{a})}$

$\$ 8.70 / 1000 \mathrm{lb}^{(\mathrm{b})}$

$\$ 0.14 / 1000 \mathrm{gal}^{(\mathrm{c})}$

(a) Value for electricity cost provided by WHC (1987) was converted from 1988 to 1991 dollars using the Marshal and Swift Cost Index for electrical power.

(b) Value for steam cost provided by WHC (1987) was converted from 1988 to 1991 dollars using the Marshal and Swift Cost Index for steam power.

(c) The cooling water cost from Peters and Timmerhaus (1968) was converted from 1967 to 1991 dollars using the Marshal and Swift Cost Index for electrical power. 
The HWVP is expected to produce 220 pounds/hour of glass with a plant operational availability of 70\% (WHC 1987). However, even during periods of shutdown and melter idling, the off-gas system will continue to operate to maintain the pressure confinement boundary. Therefore, annual operating costs of the off-gas systems are based on 8760 hours of operating time per year (24 x 365).

\section{REFERENCES}

Bresser Industries Inc Indiana: "Roots Universal RAI Blowers." Bulletin

Dresser Industries Inc. 1989. "Roots RAS-J and RGS-J Whispair Blowers and Gas Pumps." Bulletin S-5219S, Connersville, Indiana.

Goulds Pumps, Inc. 1982. "Goulds Pump Manual." 4th Ed. Seneca Falls, New York.

Herborn, D. I., and D. A. Smith. 1991. Hanford Waste Vitrification Plant Preliminary Safety Analysis Report. WHC-EP-0250, Rev. 0, Westinghouse Hanford Company, Richland, Washington.

Ketema, Inc. 1989. "Sizing Data Ejector-Venturi Gas Scrubbers." Technical Supplement 7S, Ketema Schutte and Koerting Division, Bensalem, Pennsylvania.

Peters, M. S., and K. D. Timmerhaus. 1968. Plant Design and Economics for Chemical Enqineers. 2nd Ed. McGraw-Hill Book Company, New York.

Westinghouse Hanford Company (WHC). 1987. HWVP Reference Conceptual Design Report. WHC-EP-0044, Richland, Washington. 
- 


\section{DISTRIBUTION}

No. of

Copies

OFFSITE

2 DOE/Office of Scientific and Technical Information

\section{QNSITE}

DOE Richland Field Office

E. C. Norman A5-16

3 Westinghouse Hanford Company

HWP PRMC H5-51

P. Felise 66-06

E. T. Weber 66-08

18 Pacific Northwest Laboratory

L. Ballou P7-18

J. M. Creer 66-01

R. W. Goles (10) P7-01

Publishing Coordination

Technical Report Files (5) 
